\title{
A NNUAL REPORT
}

O F ACCOMPLISH MENTS

FISCAL YEAR 1994

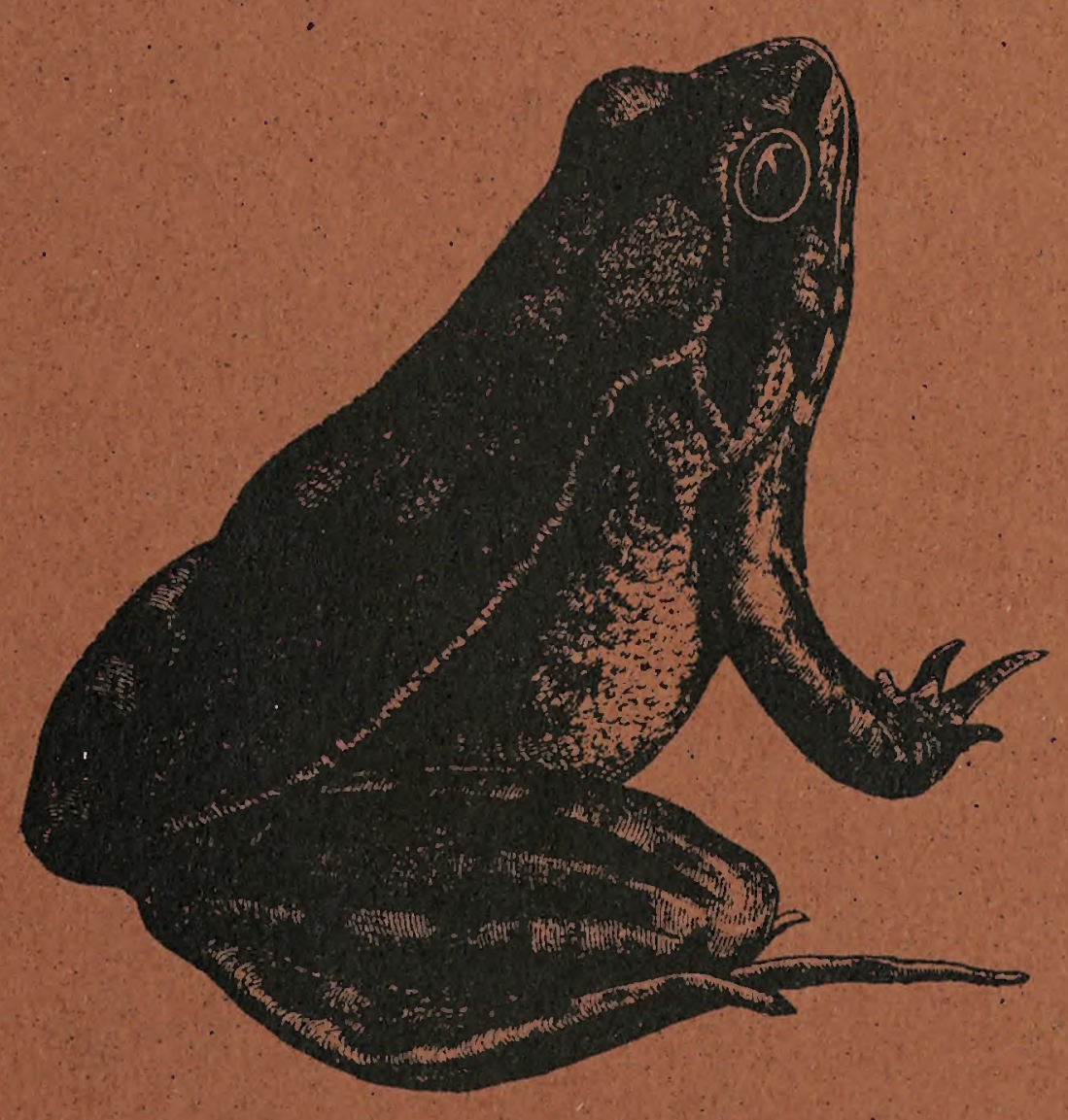

U. S. DEPARTMENT OF THE INTERIOR BUREAU OF LAND MANAGEMENT 


\section{BLM Library \\ Denver Federal Center \\ Bldg. 50, OC-521 \\ P.O. Box 25047 \\ Denver, CO 80225}




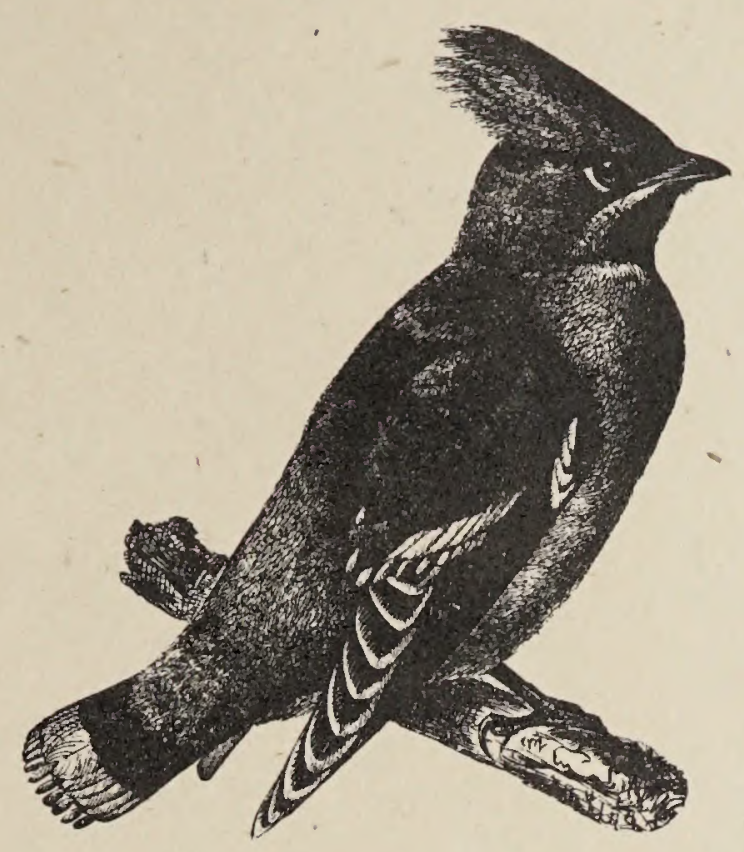

THE BUREAU OF LAND MANAGEMENT

IS RESPONSIBLE FOR THE STEWARDSHIP

OF OUR PUBLIC LANDS. IT IS COMMITTED TO MANAGE, PROTECT, AND IMPROVE THESE LANDS IN A MANNER TO SERVE THE NEEDS OF THE AMERICAN PEOPLE FOR ALL TIMES. MANAGEMENT IS BASED ON THE PRINCIPLES OF MULTIPLE USE AND SUSTAINED YIELD OF OUR NATION'S RESOURCES WITHIN A FRAMEWORK OF ENVIRONMENTAL RESPONSIBILITY AND SCIENTIFIC TECHNOLOGY. THESE RESOURCES INCLUDE RECREATION; RANGELANDS; TIMBER; MINERALS; WATERSHED; FISH AND WILDLIFE; WILDERNESS; AIR; AND SCENIC, SCIENTIFIC, AND CULTURAL VALUES. 



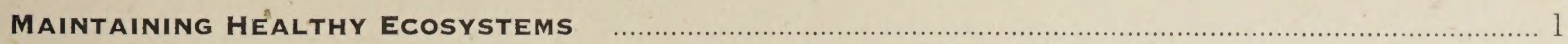

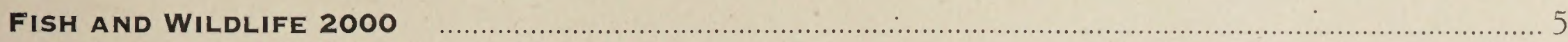

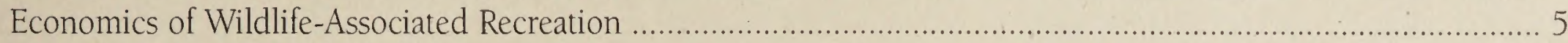

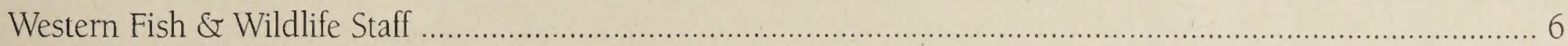

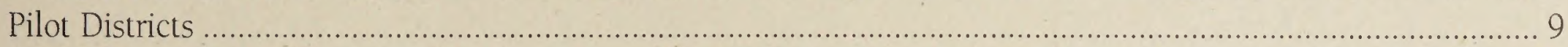

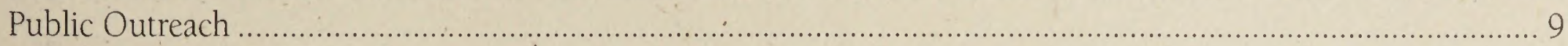

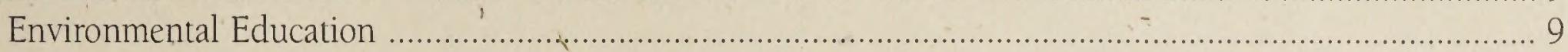

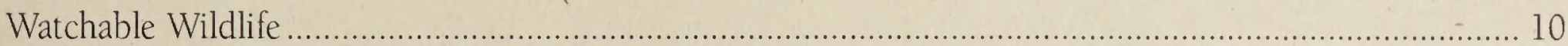

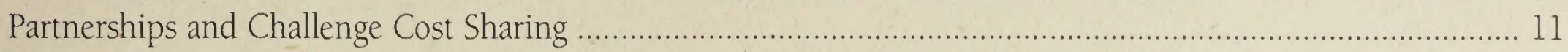

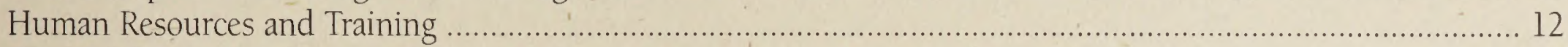

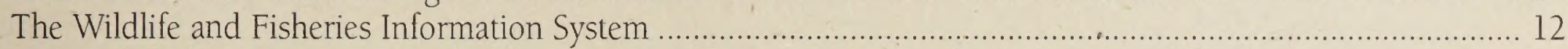

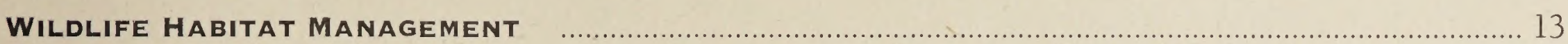

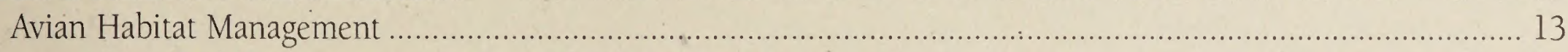

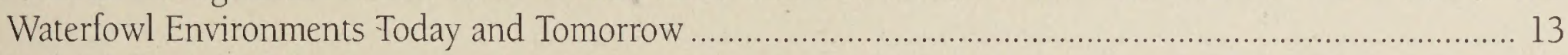

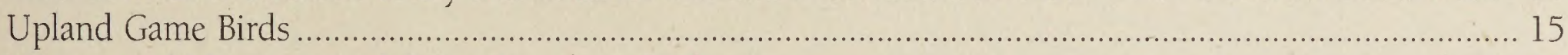

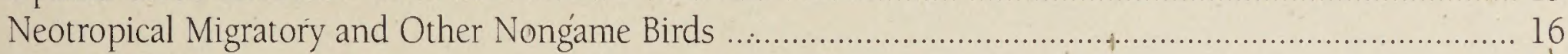

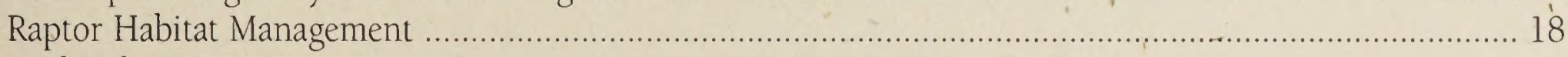

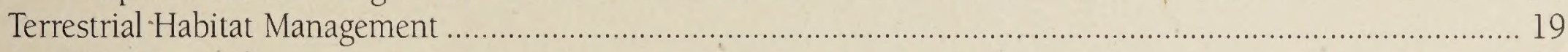

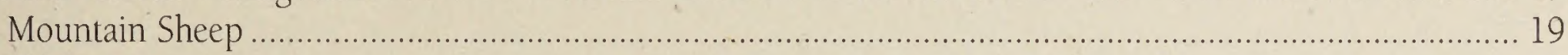

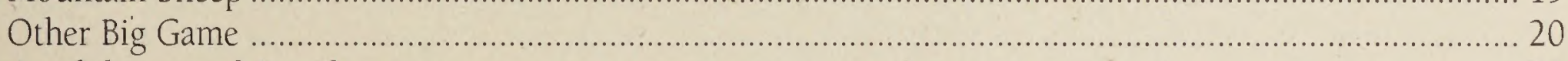

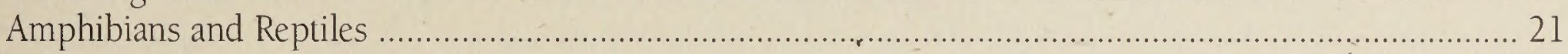

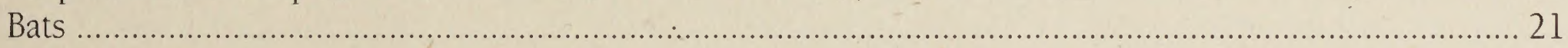

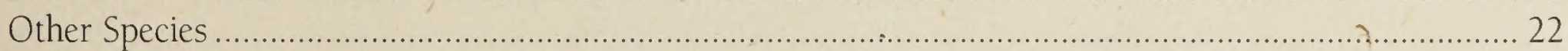

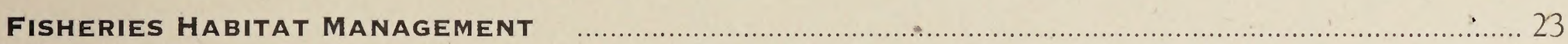

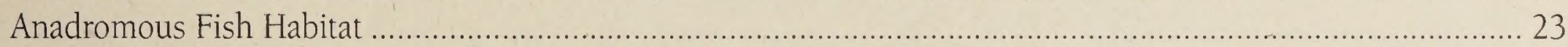

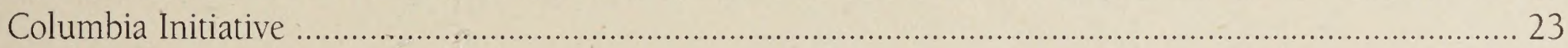

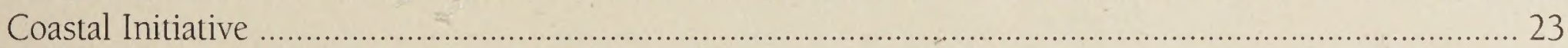

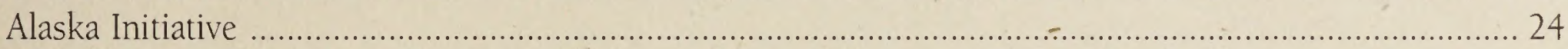

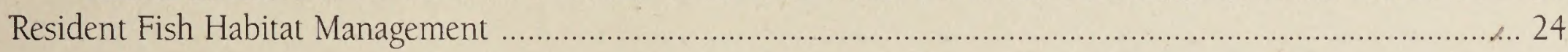

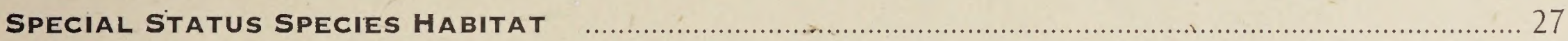

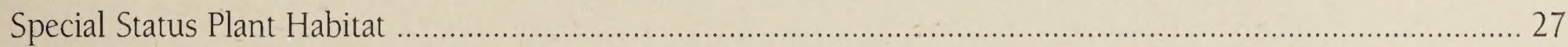

Special Status Fish Habitat and Bring Back the Natives.............................................................................. 29

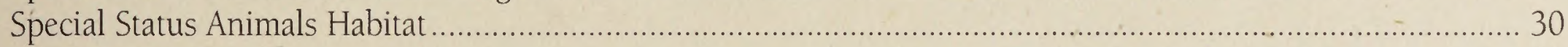

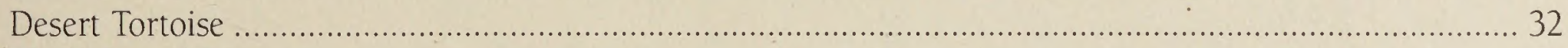

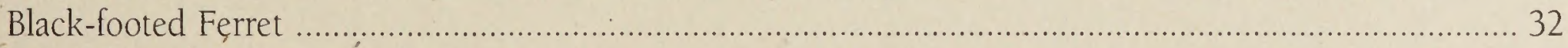

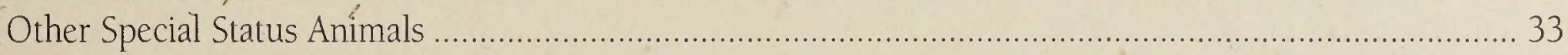

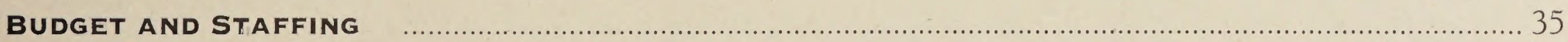

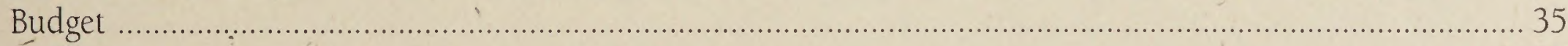

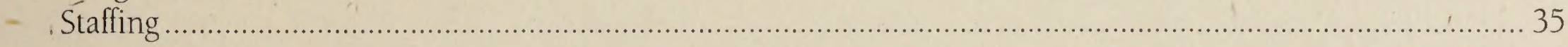

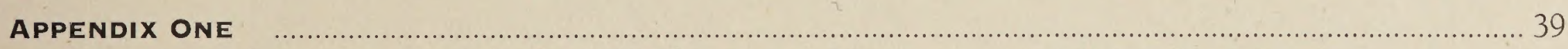

Agencies and organizations with which BLM has partnership agreements and operations

Courses completed by the National Training Center 

I n 1987, Fish and Wildlife 2000 was conceived and subtitled as "A Plan For The Future," with healthy ecosystems identified as the fundamental building blocks for success. Since its inception, Fish and Wildlife 2000 consistently has responded to changing needs and opportunities in conserving fish, wildlife and plant resources on America's public lands. New standards are now shaping the future of fish and wildlife habitat: Ecosystem Management, Biological Integrity, Landscape Analysis, Land Health, Adaptive Management, and Plans for Sustainable Economies and Sustainable Environments.

In August 1994, the Bureau of Land Management announced its Corporate Agenda. This "Blueprint for the Future" listed five concerns:

\section{- Maintaining Healthy Ecosystems}

- Serving Our Current and Future Publics

- Improving The Way We Do Business

\section{- Developing Collaborative Leadership}

- Diversifying Our Work Force

Under the top priority, Maintaining Healthy Ecosystems, three items appeared:

- Implement the President's Forest Plan, Pacific Anadromous Fish Plan, Mining Law Reform and Rangeland Reform

\section{- Assess, document and monitor conditions}

- Develop scientifically sound, consensusbased management decisions

Fish and Wildlife 2000 is ideally suited to implement the top priority. Healthy ecosystems are supported by integration of Fish and Wildlife 2000 strategies and ecosystem management principles, and through new tools and training. Also, we are sustaining and expanding partnerships with "single-focus" constituent organizations, all of whom have an interest in BLM maintaining healthy and productive ecosystems.

ECOSYSTEM MANAGEMENT SELECTED ACCOMPLISHMENTS

In Arizona, a reorganization eliminated Districts' Divisions of Resources and replaced them with a few resource advisors. People not selected as resource advisors were assigned to "on-the-ground" positions in Resource Areas. State Office senior technical specialists then trained teams in each Resource Area in interdisciplinary processes, focusing on an ecosystem with multiple issues. Progress was made in addressing management issues in the Black Mountains, Gila Box, Mt. Trumbull and Muleshoe Ranch ecosystems

The Mary's River project in Nevada is an ecosystem-based, interagency effort to improve land use practices throughout an entire watershed. The major objective is to improve about 80 miles of stream and riparian habitat, emphasizing recovery of Lahontan cutthroat trout, a federally listed threatened species.

Nevada's Bruneau River project is a cooperative effort to improve stream and riparian habitat, enhance big game habitat and attain functional watershed conditions. BLM, U.S. Forest Service, Nevada Division of Wildlife, Rocky Mountain Elk Foundation, National Fish and Wildlife Foundation, and private landowners are cooperators. This area is part of the "Seeking Common Ground" initiative and also part of the National Elk/Livestock Demonstration Area.

The Phoenix Resource Area and U.S. Forest Service organized interested groups into the Agua Fria Grasslands Coalition and developed management objectives for the 270,000-acre Agua Fria Grass- land Ecosystem. With livestock grazing of riparian areas now restricted to winter use on three allotments, habitat improvement is occurring along 16 miles of streams.

A statewide interdisciplinary team in Arizona developed guidance for ephemeral livestock grazing on BLM land to ensure consistency among districts and resource areas. The guidance incorporates standard safeguards to ensure sustainability of wildlife habitat and protect against resource damage.

An Ecosystem Management Team comprised of a BLM interdisciplinary team, other agencies, and private individuals is developing a plan to manage the Black Mountain Ecosystem in Arizona. Major issues include forage allocation among desert bighorn sheep, mule deer, livestock and wild burros.

The Tucson Resource Area is a major partner in the interagency Muleshoe Ecosystem Management Plan. Seven perennial streams in the ecosystem are habitat for five native fish species, all of which are federal candidate species. Over 35 other special status species inhabit the ecosystem, including peregrine falcons, zone-tailed, black and gray hawks, neotropical migratory birds and leopard frogs.

In California, a rapidly growing population has damaged one of the world's most biologically diverse areas. BLM is one of the many agencies and groups to sign the Memorandum of Understanding

(MOU) on

California's

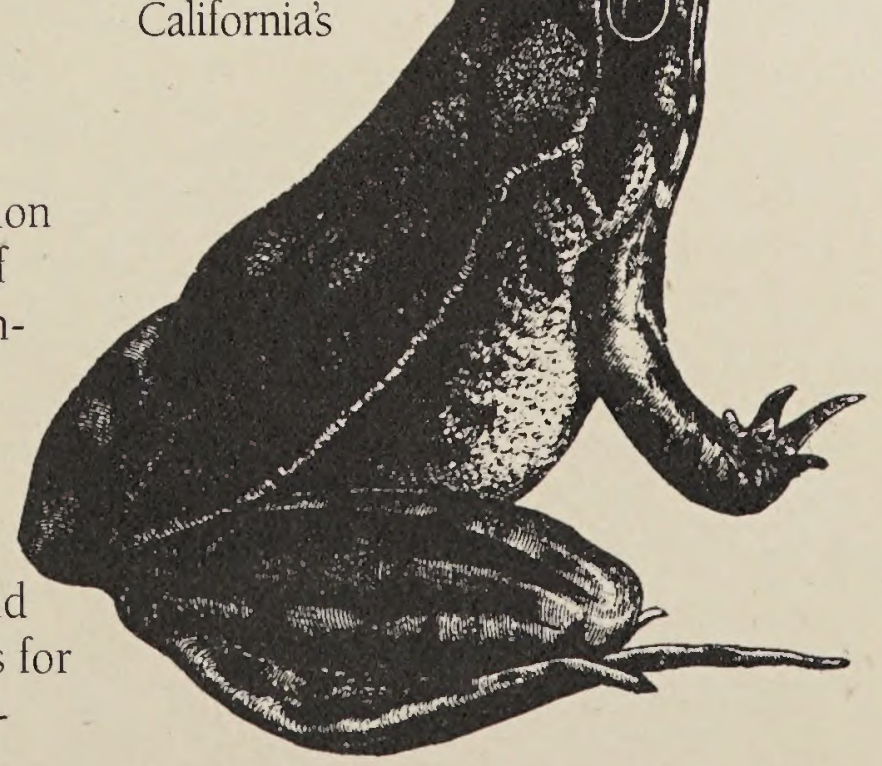


Coordinated Regional Strategy to Conserve Biological Diversity. The MOU encourages plans that emphasize management of entire ecosystems without regard to political boundaries. Healthy ecosystems and conservation of biological diversity are the ultimate objectives of these plans. The planning efforts include:

\section{West Mojave Coordinated}

Management Plan - Several federal and state agencies, three counties, and 11 towns and cities are partners in planning for this 9.5 million acre area in the western Mojave Desert. The plan addresses several listed animal species and many candidate plant species, and will implement the desert tortoise recovery plan. It will also serve as a habitat conservation plan for private lands

Carrizo Plain Natural Area -

The Carrizo Plain is the largest remaining representation of the San Joaquin Valley Biogeographic Province. BLM, The Nature Conservancy, U.S. Fish and Wildlife Service, California Department of Fish and Game and private industry are major cooperators in managing the area.

Fort Ord Biodiversity Management - In 1994 BLM assumed management for about 10,000 acres at Fort Ord in Monterey County. The best remaining example of maritime chaparral in the world is found here. The area's other important habitats include rare dune complexes, vernal pool wetlands and native grasslands, which are home to 44 threatened, endangered or rare plants and animals. A Coordinated Resource Management Plan is being developed for the entire ecosystem.

Klamath Bioregional Planning Efforts - California BLM participates in many planning activities that include federal and state agencies, private industry and local citizen groups. One planning effort is for the Grass Valley Creek Watershed, aimed at restoring anadromous and resident fisheries.

Peninsular Ranges Coordinated Management Plan - The peninsular bighorn sheep, currently listed as threatened by the state and proposed for federal listing, is the focus of this ecosystem-based plan. Least bell's vireo and the desert slender salamander, both endangered, are also considered in the plan. Five cities, three counties, the Agua Caliente Indian Tribe and the Torres-Martinez Indian Tribe are working with state and federal agencies to resolve conflicts on the 560,000 acres of the eastern desert slopes of the peninsular ranges.

South Coast Ecosystem Management - Working groups are developing ecosystem plans for the coastal sage scrub community, which supports several listed and candidate species, including the Coastal California gnatcatcher and the orange-throated whiptail.

In California's Goose Lake Basin, BLM and private landowners formed a bi-county committee to devise voluntary habitat enhancement programs for public and private land that will recover the remaining native fish species of the basin.

In collaboration with the University of California, Davis, California Department of Fish and Game, U.S. Forest Service and Soil Conservation Service; BLM conducted a series of one-day meetings on ecosystem management at every BLM office in California. Nicknamed "Creekside Chats," the sessions were informal discussions aimed at reaching all BLM employees in California.

In Nevada, livestock use on about 50 percent of grazing allotments has been adjusted. In 1994, 33 decisions for changes in season of use and/or reductions in livestock use were issued, to meet ecosystem and wildlife habitat objectives. About 6.5 million acres of uplands are expected to gradually improve as a result. Almost 3,000 acres of meadows and riparian areas and 250 miles of streams are expected to improve by eliminating hot-season grazing or providing complete protection from grazing.
In Nevada's Elko Resource Area, BLM provided resource expertise and leadership in teaming up with Newmont Gold Co. and Maggie Creek Ranch to restore and enhance more than 100 miles of stream and wetland habitat along Maggie Creek and its tributaries. Riparian fencing, livestock grazing management and conservation easements are among the measures used. The goal is to demonstrate compatibility of mining, ranching, recreation, environmental and natural resource values on private and public lands, and most project costs will be borne by private land owners.

The Owl Mountain Ecosystem Plan in Colorado created a widebased partnership to resolve vegetative resource conflict and improve the health of the land. BLM is leading the effort, which involves 240,000 acres, almost 60 percent of it publicly owned. The Colorado Division of Wildlife is providing a full-time project coordinator, and operational funds will come from BLM, the U.S. Forest Service, the U.S. Fish and Wildlife Service and the Seeking Common Ground Committee.

On-the-ground work is underway. A water system and pipeline now disperse livestock and big game over a four mile area, and headgates were installed in an irrigation system to flood uplands for waterfowl nesting cover. Three studies will contribute to knowledge about grazing use, bird breeding, and soils in the area.

In southwestern Colorado, a 20-million acre interagency project using satellite imagery is being used to classify vegetation in a Geographic Information System format.

The Coordinated Resource Management Plan for 115,000 acres of the Dry Creek Basin watershed in Colorado was completed. Riparian inventories were completed on 66 miles of stream, and sage grouse lek searches conducted on 60,000 acres.

The Gunnison Basin Ecological Classification and Inventory continued, in cooperation with the U.S. 
Forest Service and Habitat Partnership Program. Aerial photo interpretation of natural plant communities in Colorado was completed on - 38,000 acres. To date, 448,000 acres of classification field work have been completed.

The vegetation analysis will assist in determining habitat capability for big game and livestock in areas of forage conflicts. In Colorado, after wildfires burned crucial big game winter ranges, rehabilitation work began on 75,000 acres. Reseeding began to reduce cheatgrass invasion and re-establish critical browse. The work is funded through partnerships with other agencies, private landowners and wildlife conservation organizations, including the Rocky Mountain Elk Foundation and The Nature Conservancy.

Inventory work in Colorado allowed BLM and the U.S. Forest Service to use similar baseline information in planning for the 4 Mile/Divide Creek Ecosystem.

Utah's Richfield District is a partner in the 426,639 acre Monroe Mountain Demonstration Area, managed by 21 different organizations and many individuals. The goal is to enhance the ecological integrity of the area through ecosystem mānagement, while providing for human values, products and services.

The Moab District is participating in the Canyon Country Partnership, a local initiative dedicated to maintaining ecosystem health while providing for the needs of people in southeast Utah. The focus is on the impacts of recreation use, and developing an ecosystem characterization proposal for the 15 million acre area. Work began on the Eastern Utah Resource Management Plan, which includes all of the Colorado Plateau in.Utah. Ecologically based land use planning for three contiguous Resource Areas is the focus. The Shoshone Basin Planning Committee in Idaho's Burley District, will address ecosystem-level management of critical sage grouse and pronghorn habitat to solve conflicts among wildlife habitat needs, livestock management and vegetation manipulation.

Chilly Slough, a 4,400 acre montane wetland in central Idaho, is being protected in perpetuity through the cooperative efforts of private lañdowners, BLM, Idaho Department of Fish and Game, U.S. Fish and Wildlife Service, The Nature Conservancy and Ducks Unlimited. With grants from the North American Wetlands Conservation Council and other support, progress has been achieved in protecting the slough's wetland values, consolidating public ownership and improving management of this important wetland.

A floristic inventory was begun in the Rock Springs District through a Challenge Cost Share agreement with the Rocky Mountain Herbarium at the University of Wyoming. Last year's inventory for 750,000 acres of the Upper Green River Basin was completed. During the next four years, inventories will cover 3.5 million more acres.

As part of the Currant Creek/ Sage Creek National Showcase
Habitat Management Plan, prescribed burning was carried out on 4,000 acres in the Rock Springs District in 1994. BLM, Wyoming Game and Fish Department, Rocky Mountain Elk Foundation, livestock permittees, Trout Unlimited, Sweetwater Wildlife Association and Bowhunters of Wyoming are cooperators in the project.

Development of the Jack Morrow Hills Ecosystem Plan in Wyoming continues. During 1994, 9,000 acres were burned for watershed rehabilitation and vegetation biodiversity on Steamboat Mountain in cooperation with the Wyoming Game and Fish Department and Rocky Mountain Elk Foundation. A plan was completed to construct ponds in the Rock Springs District that will restore wetlands, provide fishing and other recreation opportunities, and establish an outdoor classroom for local schools: A partnership including BLM, several other federal and state agenciès and the town of Pinedale will continue the work in 1995.

SINCE ITS INCEPTION,

FISH AND WILDLIFE 2000 CONSISTENTLY

HAS RESPONDED TO CHANGING NEEDS

AND OPPORTUNITIES IN CONSERVING FISH,

WILDLIFE AND PLANT RESOURCES ON

AMERICA'S PUBLIC LAND.

NEW STANDARDS ARE NOW SHAPING

THE FUTURE OF FISH AND WILDLIFE

HABITAT: ECOSYSTEM MANAGEMENT,

BIOLOGICAL INTEGRITY, LANDSCAPE

ANALYSIS, LAND HEALTH,

adaptive management, and Plans

FOR SUSTAINABLE ECONOMIES 

S ince 1987, Fish and Wildlife 2000 has provided a strategy to manage habitat for the 3,000 species of vertebrates that live on public land. With 270 million acres, BLM is the largest public land manager in the world. These lands comprise a great variety of ecosystems and habitats, ranging from the Mojave and Chihuahuan deserts in the southwest to alpine tundra in Colorado and Arctic tundra in Alaska.

Implementation of Fish and Wildlife 2000 has been guided by a number of national strategy plans that specify' goals and objectives for particular groups of species. Thése strategic plans were prepared by teams of biologists and other natural resource professionals from BLM, other agencies and conservation organizations

The following strategic plans are currently being implemented:

Wildlife

- Desert Bighorn Sheep Habitat Management

- Nongame Migratory Bird Habitat

- Raptor Habitat Management

- Upland Game Bird Habitat Management

- Watchable Wildlife

- Waterfowl Hábitat Management on Public Lands

- Waterfowl Environments Today and Tomorrow

- A plan to manage mountain sheep on public land is in draft form.

Fish

- Fisheries Habitat Management

- Anadromous Fish Habitat Management
- Resident Fish Habitat Management

Special Status Species

- Desert Tortoise

- Rare Plants and Natural Plant Communities

- Special Status Fishes

Administrative

- Wildlife ànd Fisheries Information System

- Career Management Team Findings for Wildlife and Fisheries Biologists

- Training BLM Wildlife and Fisheries Program Personnel

- Staffing for BLM Wildlife and Fisheries Program

BLM is shifting away from single species management and toward an ecosystem perspective. Ecosystem management widens the scope of species that require consideration in decision-making processes, from traditional game species to such groups as neotropical migratory birds, bats, reptiles and amphibians and invertebrates. To be truly effective in landscape-

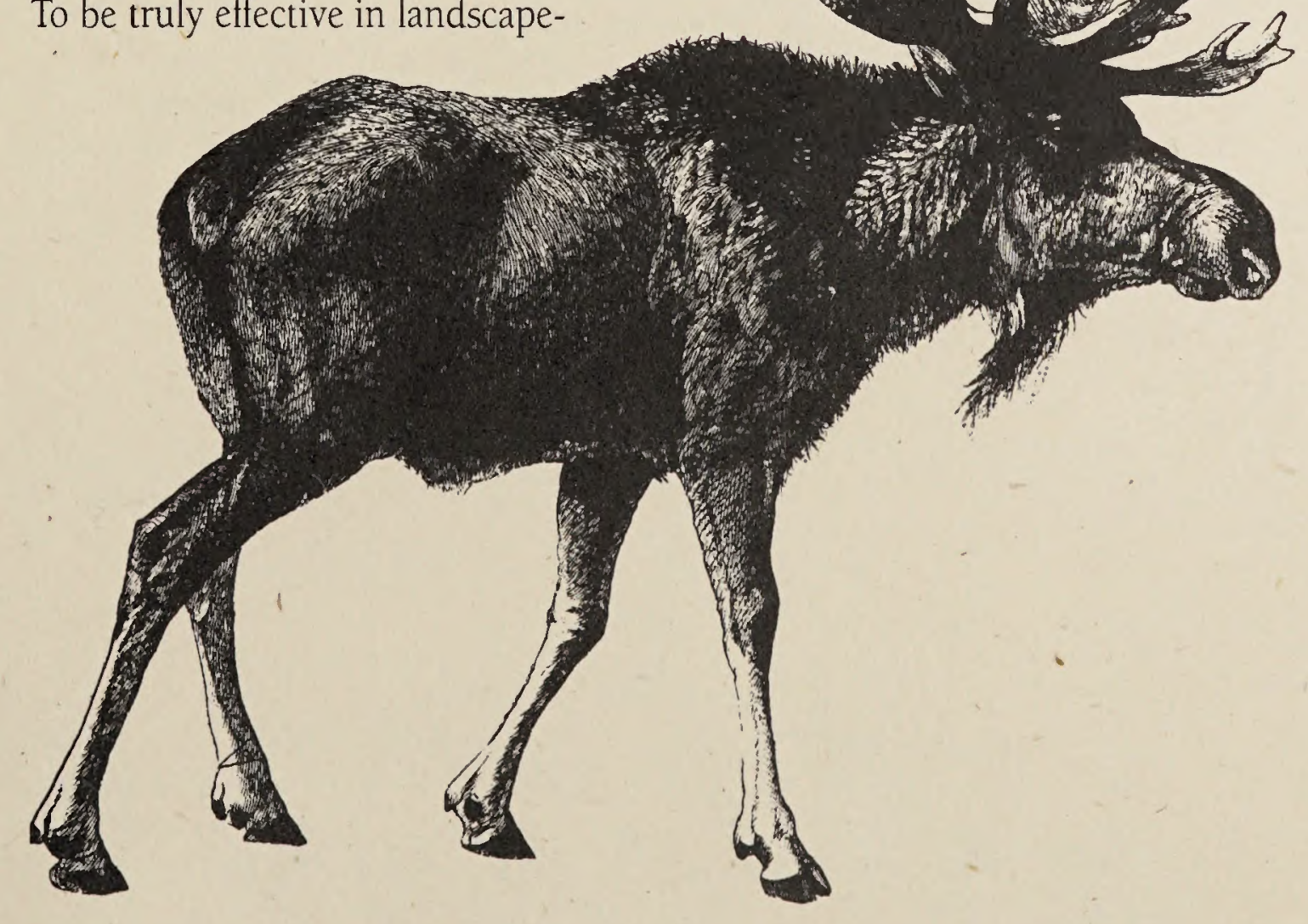

level management, even more of its components, such as insects and soil considered.

ECONOMICS OF WILDLIFE-

ASSOCIATED RECREATION

In 1991, more than half of the related recreation.

These words from the 1991 National Survey of Fishing, Hunting, and Wildlife-Associated Recreation plainly say how important wildlife is to Americans. The pleasure of seeing a golden eagle soar over a wilderness canyon or watching a chinook salmon leap a waterfall always have been of immense aesthetic value, but only recently have economists been able to measure the economic importance of nonconsumptive values. Added to hunting and fishing expenditures, the contribution of wildlife to the nation's economy in 1991 totaled about $\$ 59$ billion. microfauna, must ultimately be people in the United States 16 years old and older enjoyed some type of wildlife- 
WESTERN FISH AND WILDLIFE STAFF

To better reflect BLM's adoption of ecosystem management, the Western Fish and Wildlife Staff would be renamed the Ecosystem Resources Support Group. The group's primary roles are to help implement the corporate agenda, enhance communication and cooperation with the hundreds of partners that work with BLM in ecosystem management, and to provide technical expertise to field biologists within the Bureau (Appendix 1). During 1994, a group definition and charter for 60 teams were developed.

As a result of the Western Fish and Wildlife Staff's efforts to cultivate and maintain partnerships, direct investment, contributions, matching funds, volunteers and technology, the Bureau realized an additional $\$ 15$ million dollars in 1994. Given current projections, it is estimated that this investment trend will increase to above $\$ 18$ million annually by 1997 . (See Figure 1.)

Selected accomplishments for the past year are listed below for current program managers.
ANADROMOUS FISH HABITAT

SELECTED ACCOMPLISHMENTS

The program manager completed the Coastal and revised Columbia Anadromous Fish initiatives, which will become part of the updated Anadromous Fish National Strategic Plan.

Two scientific papers, Temporal Variation in Abundance of an Isolated Population of Cutthroat Trout in Western Oregon, 1981-1991, and Evaluation of Instream Structures in a Coastal Oregon Stream, 1981-1993, were completed for the North American Journal of Fisheriés Management.

We participated in BLM U.S. Forest Service Core Response and Implementation Teams for Pacific Anadromous Fish Habitat and Watershed Conservation Strategy Environmental Assessment.

AQUATIC ECOLOGY PROGRAM SELECTED ACCOMPLISHMENTS

BLM now operates or supervises 90 percent of the aquatic macroinvertebrate processing lab work at Utah State University.

The lab analyzed 1,081 aquatic macroinvertebrate samples from 13 states last year and responded to over
FIGURE

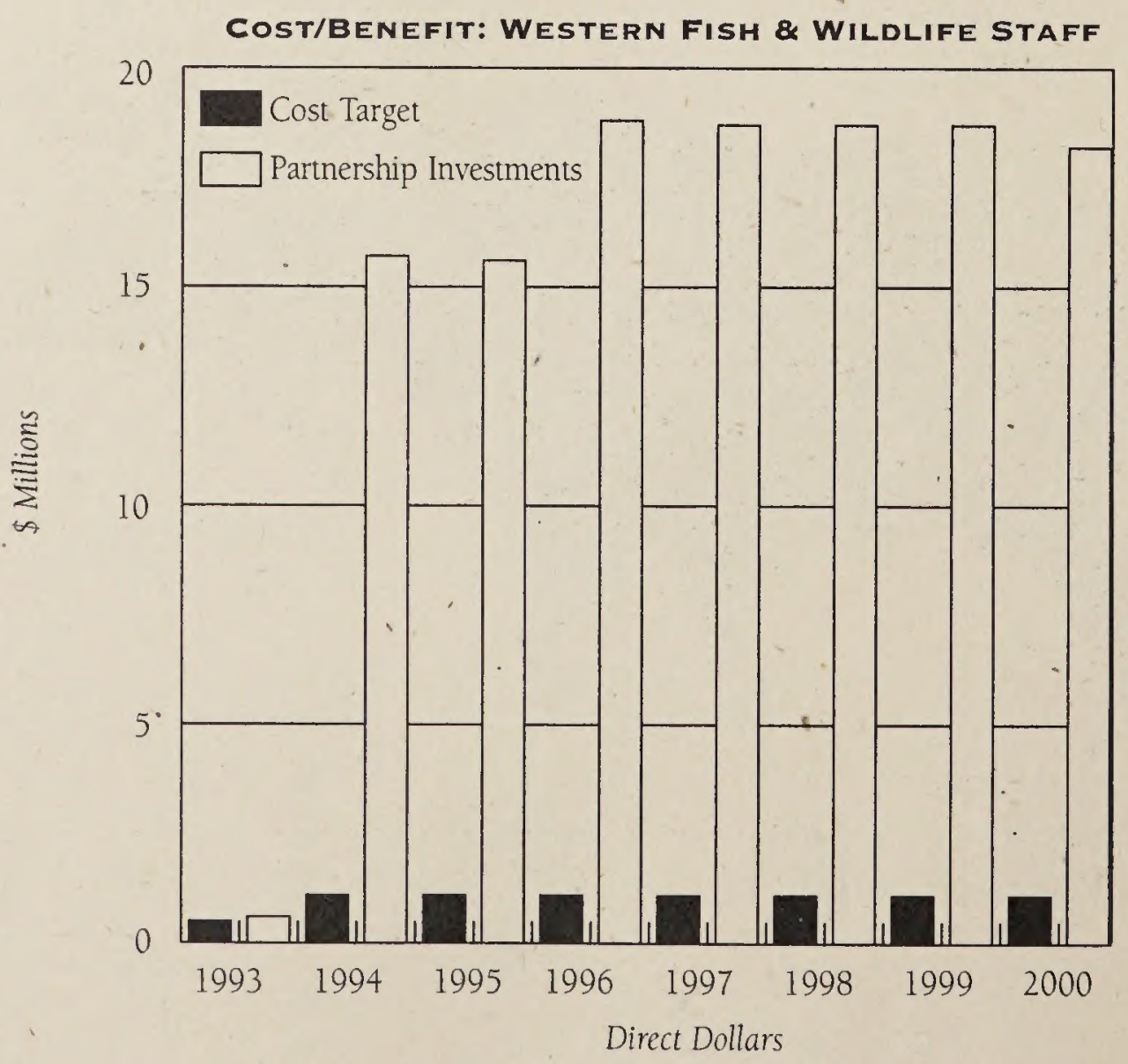

200 requests from BLM, U.S. Forest Service and state wildlife agency field offices for technical assistance.

Research was begun on the Green River, downstream of Flaming Gorge Dam, to assess the effects of dam operations on aquatic resources. The Bureau of Reclamation, U.S. Forest Service, Utah Division of Wildlife Resources and Western Area Power Administration are major cooperators.

\section{LANDSCAPE ECOLOGY MODELING AND ANALYSIS SELECTED ACCOMPLISHMENTS}

The Landscape Ecology Modeling and Analysis Center (LEMA) continued developing a prototype for drainage basin analysis on the Bear River in Idaho, Utah, and Wyoming, in collaboration with the U.S. Forest Service. The prototype is being developed'as a tool for conservation management of the Bonneville Cutthroat trout.

A cooperative effort among agencies and other organizations to map and evaluate neotropical migratory bird habitats in the Great Basin Region as part of Partners in Flight was initiated.

The assessment of need for training, equipment and support for those portions of Alaska; California, and Idaho that are within the Pacific Anadromous Fish Habitat and Watershed Conservation Strategy area was completed.

As part of a National Aeronautic and Space Administration grant, the Landscape Ecology Modeling and Analysis Center helped to start a costsharing project that uses modern technology for monitoring rangeland conditions.

In cooperation with Alaska's Anchorage District, continued prototyping the use of scanned aerial photography and image processing to classify in-stream microhabitat for anadromous fisheries. The Unalakleet National Wild and Scenic River is being used as the test site. 
NEOTROPICAL MIGRATORY AND OTHER NONGAME BIRDS SELECTED ACCOMPLISHMENTS

The program manager participated in the Research Working Group of Partners In Flight to help establish national priorities for research. The document produced will guide the National Biological Survey and academic researchers.

Presentations were made on monitoring riparian bird species and riparian vegetation at the National Audubon Society's Western Regional Conference in Monterey, California. Assistance was provided to the Point Reyes Bird Observatory and Big Sur Ornithological Laboratory to conduct workshop on field techniques for monitoring birds and discussed international partnerships with representatives from Panama (Panama Audubon Society), Costa Rica (Tropical Conservation Newsbureau) and Mexico (University of Michoacan).

The program manager participated in planning the International Workshop on Conservation of Grassland Ecosystems with the National University of Mexico, International Council of Bird Preservation (Canada) and U.S. Fish and Wildlife Service.

Annual reports of BLM accomplishments were prepared for publication in the spring issues of the Partriers In Flight newsletter, and periodic annotated review of recent scientific literature on neotropical migrants for the newsletter.

Bilingual posters (Toward Ecosystem Management in the Bureau of Land Management and Reversing the Loss of Biodiversity in the Great Basin, USA), and an oral presentation Teaching Environmental. Education

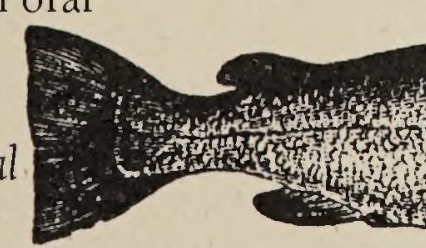
Through Project WILD were presented at the International Wildlife Management Congress in San Jose, Costa Rica. The oral presentation led to enthusiastic contacts by representatives of 14 foreign countries (e.g., India, China, France, Argentina, Kenya).
In Costa Rica, we began building a network of Latin American biologists/managers/environmental educators, to further the international objectives of our Nongame Migratory Bird Habitat Management Strategy Plan.

The program manager discussed cooperative projects for conservation of tropical ecosystems where migratory birds winter, with participating biologists from Mexico, Costa Rica, Guatemala, Panama, Univ. Missouri, Univ. Nevada, Univ. New Hampshire, Univ. Arizona, U.S. Agency for International Development, U.S. Fish and Wildlife Service, Wildlife Conservation International, World Wildlife Fund, Rainforest Alliance, and several others.

The book chapter, The Effects of Livestock Grazing on Neotropical Migratory Land Birds in the Western U.S. was completed for publication in Population Ecology and Conservation of Neotropical Migratory Birds, Oxford University Press.

In cooperation with the National Training Center, the first Neotropical Migratory Bird Conservation course in Sierra Vista, Arizona, was designed and conducted.

\section{RESIDENT FISH HABITAT MANAGEMENT SELECTED ACCOMPLISHMENTS}

Strategies for implementing Bring Back the Natives with National Fish and Wildlife Foundation were developed, as was a process for project selection.

Working with BLM fisheries biologists in southern Colorado, Lake 8. Havasu (Arizona), the Vernal District 2. (Utah), Salmon District southern
Wyoming ras committee. To date, the board has

and Alaska State Office, riparian and fisheries projects were reviewed and discussion was held about on-theground implementation.

The program manager participated in the Friends of the Bull Trout conference held in Calgary, Canada; the Western Division and national meetings of the American Fisheries Society in Flagstaff Arizona; and, the Western Association of Fish and Wildlife Agencies annual conference.

UPLAND GAME HABITAT MANAGEMENT SELECTED ACCOMPLISHMENTS

Cooperative efforts were expanded among the Washington Department of Wildlife, the Washington Department of Natural Resources, and BLM to conserve the shrub-steppe ecosystem in eastern Washington for 11 special status species including the western sage grouse, Columbian sharp-tailed grouse, and pygmy rabbit. It is anticipated that the three agencies and the U.S. Fish and Wildlife Service will enter into a.Conservation Agreement in 19,95.

The Western Fish and Wildlife Staff sponsored a mountain quail conservation workshop that was attended by numerous state and federal agencies, universities, and private organizations such as Pheasants Forever and Quail Unlimited. As a result of the workshop, an interagency technical committee was established to oversee the development of a Conservation Assessment/Strategy for this species. Major cooperative funding to initiate a new research project has been obtained from the National Fish and Wildlife Foundation through a Quail Unlimited grant and by Idaho Power Company.

As a result of BLM's commitment to the management and conservation of upland game, the Western States Sage and Columbian Sharp-tailed Grouse Committee is considering the addition of a new

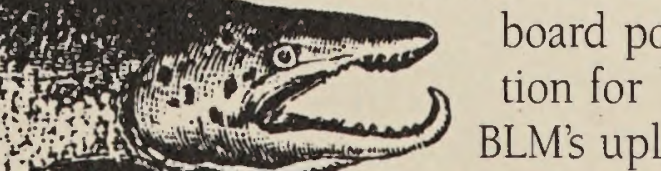
board posiBLM's upland 
only included state wildlife agency representatives.

BLM was represented by a Western Fish and Wildlife Staff member at the Forest Grouse Symposium in Corvallis, Oregon, participating in the panel on Biology, Management,

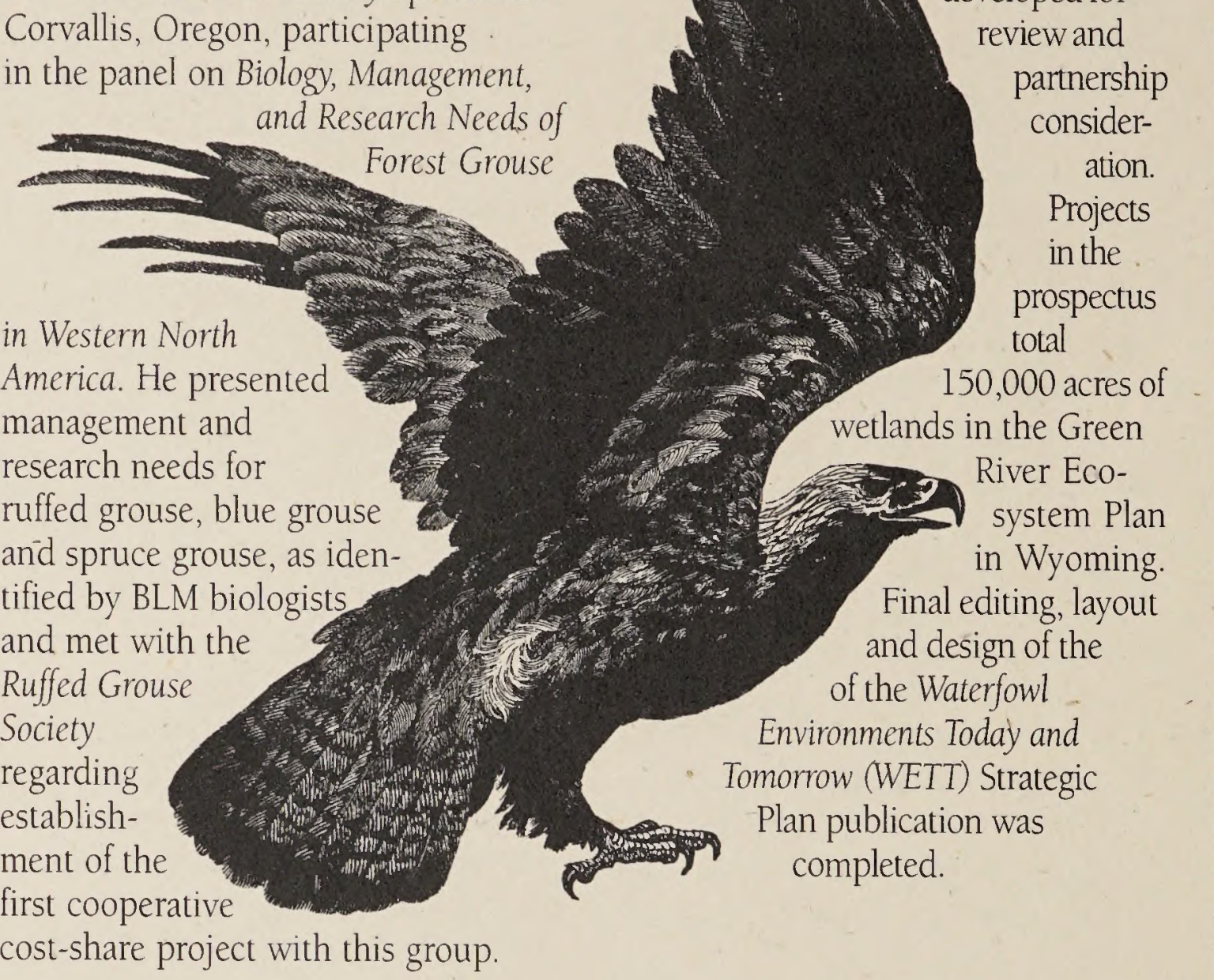

WATERFOWL ENVIRONMENTS TODAY AND TOMORROW (WETT)

SELECTED ACCOMPLISHMENTS

The program administrator helped in the formation of the Intermountain West Joint Venture. In coordination with the U.S. Forest Service, U.S. Fish and Wildlife Service and Bureau of Reclamation, an Interagency Agreement concerning the hiring and support for the Intermountain West Joint Venture Coordinator was prepared and signed. The staff coordinated with the Regional Director, Great Plains Region, Bureau of Reclamation and the Regional Project Planning Administrator in Billings, Montana, to establish the Interagency Wetland Project Review Team. The Cooperative Wetland/Riparian Project Review Team meeting between Bureau of Reclamation, Great Plains Region and BLM Montana, Wyoming and Colorado was held and fifteen projects were reviewed. Five BLM projects are earmarked for Bureau of Reclamation cooperative funding, which will total over $\$ 180,000$. A Wetland Project Prospectus for Ducks
Unlimited /Central
Flyway Office was N. 14 developed for (1) in the prospectus total res of SELECTED ACCOMPLISHMENTS
S

The program manager provided . environmental education liaison with Western Regional Environmental Education Council, North American Association for Environmental Education, University of Wisconsin at Stevens Point, National Project WET (Water Education for Teachers), and the International Association of Fish and Wildlife Agencies.

A proposal was developed for a nationally televised program about bat conservation, in conjunction with Bat Collservation International.

Preparations for the National Watchable Wildlife Conference in Corpus Christi, Texas, were coordinated with other national Watchable Wildlife partners including Defenders of Wildlife, Department of Defense agencies, U.S. Fish and Wildlife Service, U.S. Forest Service, and the International Association of Fish and Wildlife Agencies in carrying out the conference.
A review was completed on the national "white paper" titled Goals and Priority Action Projects: Environmental Education about Fish and Wildlife Conservation, as part of a national consortium brought together by the National Fish and Wildlife Foundation to improve environmental literacy in the United States and elsewhere.

BLM was represented at the North American Association for Environmental Education annual conference held in Mexico on the Yucatan Peninsula, networking and sharing information with Mexican and Central and South American environmental educators.

A meeting with representatives of Wildlife Forever to evaluate and pursue development of a dualpurpose Watchable Wildlife/Environmental Education traveling activity trunk was held. The trunk would contain spotting scopes, several pairs of binoculars and curriculum materials for use in teaching students about wildlife observation.

A Western Fish and Wildlife Staff member attended national Watchable Wildlife Steering Committee meetings, presenting updates on BLM's Watchable Wildlife program. He discussed status of the initiative in several states, the redesigned training course, and unmet program implementation needs.

Western Fish and Wildlife Staff participated in the North American Wildlife and Natural Resources Conference, representing BLM at numerous International Association of Fish and Wildlife Agency meetings including Land Resources Committee, Ad Hoc Wildlife Diversity and Funding Committee, Education Committee and Wildlife Diversity and Watchable Wildlife Committee.

Western Fish́ and Wildlife Staff represented BLM at the National Project WILD Coordinators' Conference in Wakefield, Virginia, and participated in long-range planning for the Project WILD program. At a meeting with representatives of the 
International Association of Fish and Wildlife Agencies, Western Association of Fish and Wildlife Agencies, U. S. Fish and Wildlife Service, National Wildlife Federation, National Science Teachers' Association and others, we reviewed strategies and proposals for future actions.

We participated in the first-ever Project WILD II course. The 40+ hour advanced teacher training workshop provides educators in-depth investigations of current wildlife habitat issues. The pilot course addressed anadromous fisheries, wolves, elk, black bears, and water quality.

\section{PILOT DISTRICTS}

Under Fish and Wildlife 2000, several "pilot districts" were designated to demonstrate what can be accomplished for fish, wildlife and plants when sufficient funding and staffing. are provided. Rock Springs, Wyoming, is one of BLM's pilot districts.

Biodiversity and ecosystem management benefiting both wildlife and public land users is the focus of the Rock Springs pilot project. Emphasis on cooperative planning, volunteers and fostering partnerships helped to increase the public's involvement and interest in resource management. Inventory and monitoring were the key components of the field effort.

Two wildlife biologists and two seasonal wildlife technicians were hired as a result of pilot district funding. The added staff enabled a 300 percent increase in inventory and monitoring work compared to the previous year, and 11 projects were completed seven more than would have been possible without the extra funds.

More projects meant more partners, and more partners meant more contributions in Rock Springs. Direct contributions and donations of services amounted to an increase of $\$ 90,000$ in 1994 , when compared to the previous year. Total contributions to the Rock Spring District's wildlife program in 1994 came to $\$ 155,000$.
The pilot program in Rock Springs was a success - on the ground and in the budget.

\section{PUBLIC OUTREACH}

ENVIRONMENTAL EDUCATION

BLM field professionals recognize the need to keep Americans in touch with wildland resources. They participated in many environmental education activities in 1994. A few of the highlights are below.

- In Idaho, a statewide environmental education coordinator is supported by both the wildlife and recreation programs, and part-time coordinators have been established in each of the six districts. Activities include assisting with teacher training programs such as Project WILD, and cooperative efforts such as the "Noseto-Nose" program for school children.

The Phoenix District Office teamed up with a local high school to sponsor field trips, shadow assignments, and participate in classroom teaching, with six biologists taking part. BLM assisted one student with a science project that propagated a rare Penstemon wildflower. The student won second prize in the Central Arizona Science and Engineering Fair competition. Along with a $\$ 125$ prize, her findings were published in a national agriculturalscience industry journal.

In Oregon, 36 hikes and presentations were sponsored by BLM for school groups, outdoor education groups and native plant societies.

In the Ely District, Nevada, Bats as Keys to Biodiversity has been the theme of a program given to local school children and featured at the White Pine County Fair. The program is linked to mine inventories for bats in the Ely area. Materials and videos from Bat Conservation International help tell the story of bats in the ecosystem.

The Coos Bay District, Oregon, celebrated National Fishing Week, with help from the local Walmart store, the Berkeley Fishing Tackle
Company and the Oregon Department of Fish and Wildlife. Walmart and BLM employees presented the Pathways to Fishing, program at Walmart, with free camping and fishing provided at BLM's Loon Lake Campground. Later in the summer a fishing derby was held at Loon Lake, with over 50 local merchants donating prizes for the more than 200 people who participated.

The Rock Springs and Rawlins Districts in Wyoming updated and reprinted their respective districtwide fishing maps, both popular items with the public.

The Vermillion Resource Area in northern Arizona and the Arizona Game and Fish Department continued a six-year cooperative effort to inform hunters about how to enjoy the great outdoors without impacting wilderness, cultural, and other resources. All mule deer, bighorn sheep and pronghorn hunters were mailed the information packets before fall hunting seasons opened.

The Eastern States Office, Jackson District, and Piney Woods School, conducted a week-long environmental education camp in July at the Crows Neck Environmental Education Camp in northeast Mississippi. Students from Washington D.C. to Alaska took part in the camp.

Nevada's Elko District conducted an environmental education field trip where about 100 sixth grade students planted 550 black cottonwood trees along Susie Creek. The planting was part of a comprehensive project to restore 12 miles of stream and riparian habitat.

BLM Winnemucca District, Nevada Division of Wildlife and U.S. Forest Service joined forces to conduct a Kids Fishing Derby on Sonoma Creek, in conjunction with National Fishing Week. The event was sponsored by Raley's Superstore, American Airlines, Zebco, First Miss Gold Incorporated, Gold Fields Mining Corporation, and Coeur Rochester Incorporated. 
Over 600 youth teamed up with the California State Office fisheries management biologist to work on the Sacramento Utrban Creeks Council Creek Week project during National Fishing Week. While learning about aquatic ecosystems, they also removed trash and debris from more than ten miles of stream.

In cooperation with the National Wildlife Federation, BLM Montana helped prepare four "traveling trunks" of educational materials, for use in schools throughout the state. Prairie ecosystems are the central theme, with emphasis on black-footed ferret/prairie dog relationships.

A one-day event was held on Easter in Mecca Hills in the Palm Springs-South Coast Resource Area, California, sponsored by BLM, Joshua Tree National Monument and a local Hispanic radio station. The area is popular for Hispanic family outings, but suffered from increasing vandalism. Environmental awareness presentations included displays and hands-on wildlife experiences.

The Eastern States Office conducted its fourth "Kid's Fishing Day" on the Occaquan River in Virginia. The pairing of Washington, D.C.-area kids with local Bass Anglers Sportsman Society (BASS) members provided recreation and environmental education at the same time.

Integrating the traditional wildlife programs into ecosystem management was the theme of this year's BLM exhibit at the California State Fair. Several million people learned how the Bureau is moving ever further into holistic landscape management decisions and practices.

Montana Power Company, the Helena Chamber of Commerce and Montana Department of Fish, Wildlife and Parks jointly developed a wildlife viewing and education center below the Canyon Ferry Dam, for the public to enjoy and learn more about bald eagles.

The Guy L. Goodwin Education Center, cooperatively staffed and funded by The Nature Conservancy,
California Department of Fish and Game and BLM, opened at the Carrizo Plain Natural Area. The Center's exhibits and programs focus on the unique plants and wildlife of the San Joaquin valley ecosystem, which is home to the San Joaquin kit fox, blunt-nosed leopard lizard and saltbush scrub vegetation.

During National Wildlife Week, Richfield District personnel taught 4,000 elementary students about wildlife at school assemblies in southcentral Utah.

Idaho's Coeur d'Alene District celebrated International Migratory Bird Day by inviting the public to visit a marsh-side wildlife viewing blind at Harrison. BLM staff assisted visitors with binoculars and spotting scopes and distributed "door prizes" donated by local businesses and individuals. The surprise awards included bird feeders, bird houses and field guides.

Utah's Moab District and Canyonlands Natural History Association produced a riparian interpretive trail brochure that looks at the functions of riparian areas and human effects on them.

Idaho's Shoshone District, supported by six state and federal agencies and nongovernment organizations, produced a color brochure illustrating elk winter range and migration corridors near Sun Valley.

In October 1993, the First Annual Kids Fishing Derby was held at Lake Havasu City, Arizona, with over 800 children trying to catch the 2,000 catfish stocked in a city pond. BLM sponsored a fishing day for 33 physically and mentally challenged people, and assisted participants in fishing, provided boat rides on Lake Havasu and hosted a barbecue lunch.

In Arizona, three brochures were developed for the Lake Havasu Fisheries Improvement Program, to explain habitat management for threatened and endangered fish species inhabiting the lake. BLM and Lake Havasu High School are developing an ecosystem-oriented outdoor classroom focusing on Pittsburgh Point Cove.

In Wyoming, Rock Springs District employees, in partnership with Safari Club International's American Wilderness Leadership School, madé presentations about BLM's history, mission and programs to teachers and Safari Club sponsors. The program is presented on a bluff overlooking the Green River, emphasizing management of the river's riparian and aquatic resources.

In Idaho's Coeur d'Alene District, elementary students from 16 schools participated in the Bird on a Bag project, designing and coloring bird pictures on grocery bags. Almost 4,000 bags were distributed regionally by grocery stores during International Migratory Bird Week.

About 150 Wyoming elementary school students learned the basics of ecosystem management as part of the Platte River Resource Area's field environmental education program. Casper Mountain and the Bolton Creek Environmental Education Area provided the setting for the week-long event.

Platte River Resource Area employees teamed up with the Wyoming Game and Fish Department, North Platte Chapter of Walleyes Unlimited, Wyoming Flycasters, and the Casper Recreation Department to stage the third annual Kids Fishing Program. Forty kids participated in the four 2-hour sessions that taught youngsters the basics of fishing and environmental concepts.

WATCHABLE WILDLIFE

The network of wildlife viewing areas on public land provides opportunities for watching everything from moose to hummingbirds. More than 250 wildlife viewing areas have been designated on BLM land nationwide. Mirroring the growth of Watchable Wildlife across the nation, BLM is continuing work with many partners in moving this important conservation initiative forward. 
Activities range from jointly sponsored state wildlife viewing guides to joint funding of Watchable Wildlife specialists. Wildlife viewing area improvements are being made around the Bureau, many as partnership endeavors. Watchable Wildlife Viewing Guides that BLM has been a major partner in publishing now include Arizona, California, Colorado, Idaho, Montana, Nevada, New Mexico, North Dakota, Oregon, Texas, Utah and Washington.

\begin{tabular}{c} 
WATCHABLE WILDLIFE \\
SELECTED ACCOMPLISHMENTS \\
\hline
\end{tabular}

Idaho's Watchable Wildlife Committee is publishing Windows to Wildlife, a statewide newsletter, as part of the continuing interagency/ conservation organization partnership. Public presentations and displays about the program are frequent, including special Watchable

Wildlife sessions at The Wildlife
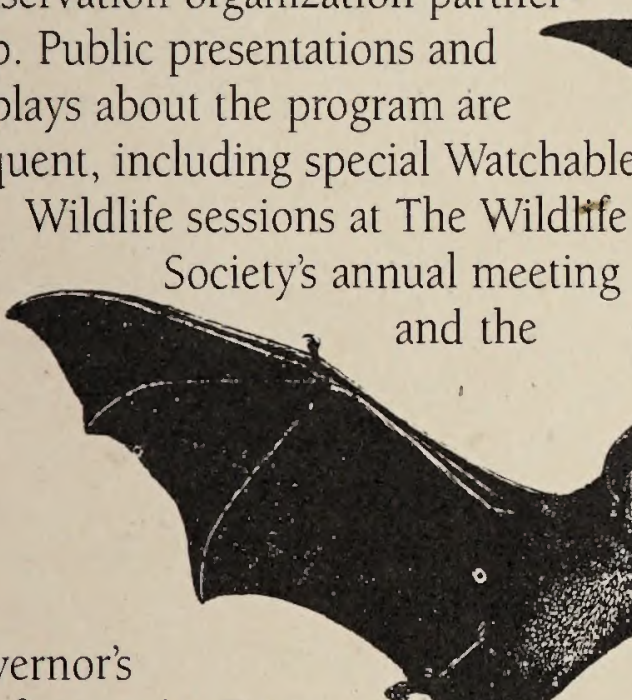

Governor's

Conference on Tourism and Recreation. A special Idaho wildlife license plate features the mountain bluebird, with proceeds going to support Watchable Wildlife and nongame programs.

Oregon BLM established several new Watchable Wildlife areas, including the Fish Trap Lake site near Spokane, Washington. Facility improvements were made at six existing viewing areas, and on-theground interpretation provided at six more.

In cooperation with the State of Arizona, highway signs and road markers for all BLM Watchable Wildlife sites in the Arizona Viewing Guide were installed. The demand for Arizona's Watchable Wildlife Viewing Guide is among the highest in the country, and a second edition is already in the works.
Nevada's Carson City District developed a Challenge Cost Share agreement with Washoe County and the Audubon Society's Lahontan Chapter to plan the Lemmon Valley Marsh Sanctuary/Wetlands Education project, a future Watchable Wildlife site. Other cooperators are the cities of Reno and Sparks, Lemmon Valley Homeowners Association, Nevada National Guard, Nevada Division of Wildlife and private citizens.

BLM volunteers in Arizona's Yuma District, organized as the Betty's Kitchen Protective Association, regularly lead interpretive tours along the half-mile National Recreation Trail at Betty's Kitchen Watchable Wildlife Area. An Arizona Game and Fish Department Heritage Fund grant enabled work to begin for improving site access, the trail, riparian habitat and interpretive facilities. The Eastern States Office

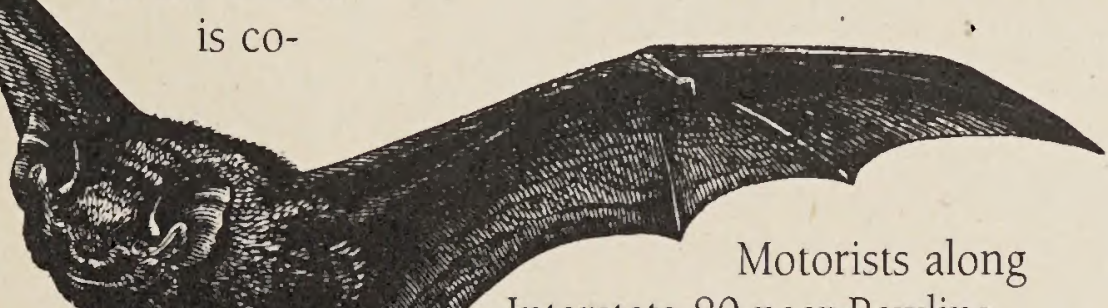
sponsoring the Michigan Wildlife Viewing Guide project. BLM administers lighthouse tracts on Lake Michigan, which are also excellent wildlife viewing areas.

In Utah's Salt Lake District, the Horseshoe Springs Habitat Management Plan Area now has an upgraded access read, parking area and barriers to protect habitat from off-highway vehicles. A new kiosk provides wildlife viewing information, and - visitors with disabilities can now safely cross an irrigation canal on an access brid'ge.

Utah's Cedar City District developed interpretive signs and a kiosk for two Watchable Wildlife areas. The Field Checklist of Utah Birds, updated by the district biologist, was published by the Utah State Office.
Interstate 80 near Rawlins, Wyoming, can quit scratching

BLM and U.S. Forest Service teamed up to provide riparian planting stock for Colorado's Fravert Reservoir Watchable Wildlife Site. The project won national partnership recognition, receiving the Forest Service Taking Wing award at the North American Wildlife and Natural Resources Conference.

Wyoming's Worland District completed improvements to the Eagle Pass Interpretative Site, which included new wildlife informational signs.

The Rock Springs District in Wyoming reconstructed a protective boundary fence on the 55-acre Duck Creek Watchable Wildlife Area, as part of overall site improvements. Plans also call for new interpretive signing, improved road and trail access, and pothole developments for waterfowl and other birds. Cooperators include the Wyoming Game and Fish Department and local citizen groups.

their heads and wondering about what seem to be platform-topped telephone poles, readily visible from the highway. Great Divide Resource Area wildlife biologists and recreation specialists installed interpretive signing at the local rest area, explaining that the structures are raptor perches and artificial nesting structures, built for ferruginous hawks.

\section{PARTNERSHIPS AND}

CHALLENGE COST SHARING

BLM appreciates the many organizations and individuals who give generously of their time, resources, and dollars to help improve fish and wildlife habitat on public land. Much of the onthe-ground work that has been accomplished on public land is possible only because of the energy and assistance of 
many conservation-minded citizens.

Though by no means complete, Appendix 1 lists many of our organizational partners.

The Fish and Wildlife 2000 Challenge Cost Share program matches private contributions with federal dollars to conduct conserva- tion work. Private and state contributions of about $\$ 28$ million in Challenge Cost Share work since 1987 have exceeded BLM contributions. Examples of projects implemented wholly or partially through Challenge Cost Share are described throughout this report.

FIGURE 2

CHALLENGE COST SHARE FUNDING HISTORY BLM 1985-1994

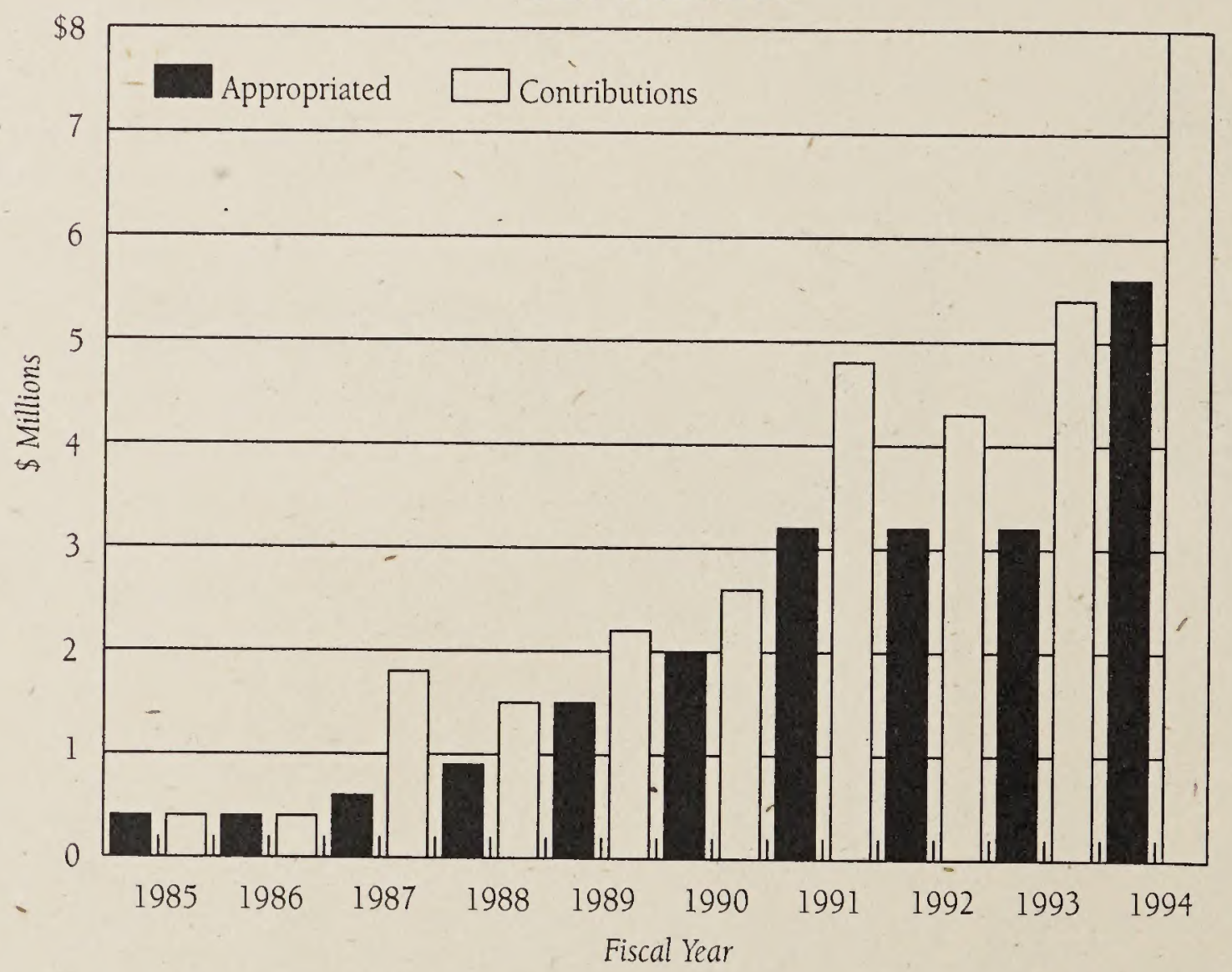

up-to-date on conserving biodiversity and applying conservation biology principleș on-the-ground. Future training courses will focus on ecosystem management principles and practices. Other courses are designed to address needs of specific wildlife or plants, for example, bats, non-migratory birds, and threatened or endangered plant and animal species.

BLM will continue to develop and refine courses as new needs arise, to ensure that employees receive the best and latest information to help them perform their jobs.

\section{THE WILDLIFE AND FISHERIES INFORMATION SYSTEM}

The Wildlife and Fisheries Information System was started in the early 1980 s to automate wildlife and habitat data. Since then, a Bureau-wide automation process evolved that caused the original concept to undergo radical changes. Now, scientific applications include terrestrial inventory and monitoring, aquatic inventory and monitoring and special status species tracking. The"latter system is the first resource program developed for BLM's new target system. The program should be ready in early 1995 . An administrative system will track progress in implementation of various Bureau planning decisions. 


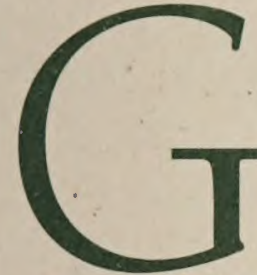
oals and objectives for management of species groups are guided by the Fish and Wildlife 2000 Strategic Plans listed earlier in this report and available from BLM's Washington, D.C. office. The visions of these plans are becoming more congruent as the need for landscape-level management emerges.

WILDLIFE HABITAT MANAGEMENT:

TO ENSURE OPTIMUM POPULATIONS,

NATURAL ABUNDANCE, AND DIVERSITY

OF WILDLIFE RESOURCES ON

PUBLIC LANDS BY RESTORING,

MAINTAINING, AND ENHANCING

HABITAT CONDITIONS THROUGH

MANAGEMENT PLANS, INTEGRATING

ACTIONS WITH OTHER USES OF PUBLIC

LAND, COORDINATING WITH OTHER

PROGRAMS AND DIRECTING HABITAT

IMPROVEMENT PROJECTS.
AVIAN HABITAT

MANAGEMENT

Over 800 species of birds either breed in North America or visit regularly from adjacent areas. The vast majority of these species are on BLM land during some of the year. Because birds occupy almost every niche in the landscape, are relatively easy to observe, and are sensitive to changes . in environmental quality, they are especially important as indicators of ecosystem health and management success.

BLM has addressed management of these species in four different strategic plans:

- Waterfowl Environments Today and Tomorrow - Waterfowl

- Upland Game Bird Habitat Management - Grouse and quail

- Raptor Habitat Management Eagles, falcons and hawks

- Nongame Migratory Bird Habitat - Shorebirds, hummingbirds, woodpeckers, warblers and all other species

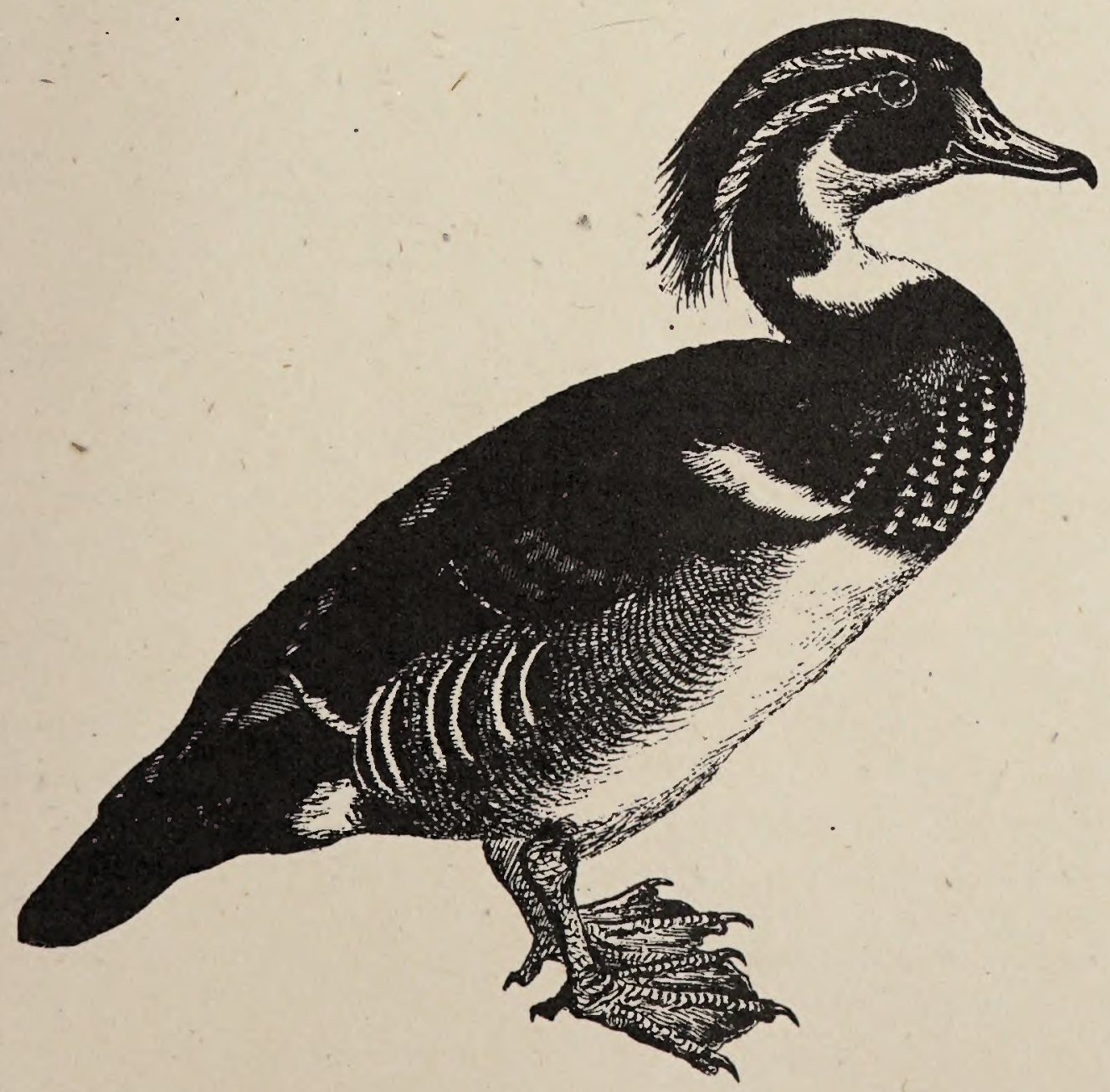

WATERFOWL ENVIRONMENTS TODAY AND TOMORROW (WETT)

WATERFOWL ENVIRONMENTS

TODAY AND TOMORROW (WETT):

TO HELP PERPETUATE A DIVERSITY

AND ABUNDANCE OF WATERFOWL

FOR THE NATION BY MANAGING

THE WETLANDS AND OTHER

HABITATS ON THE PUBLIC LAND

THAT ARE OF IMPORTANCE TO THE

MAINTENANCE OF THIS

INTERNATIONAL RESOURCE.

The strategy plan, Waterfowl Habitat Management on Public Lands, identifies areas to achieve objectives in Fish and Wildlife 2000 on over 20 million acres of waterfowl habitat administered by BLM. In 1994, BLM's Waterfowl/ Wetlands Program Manager, in coordination with BLM field personnel, Ducks Unlimited and other organizations, finalized the implementation strategy plan entitled Waterfowl Environments Today and Tomorrow.

\section{Selected Accomplishments:}

BLM enhanced or created more than 191,865 acres of waterfowl habitat in 11 states, while another 3,212 acres of wetland habitat projects are in various stages of development.

In Idaho's Burley District, riparian inventories were completed on 140 miles of stream.

The Interagency Wetland Project Review Team, comprised of the Bureau of Reclamation, Great Plains Region, and BLM in Montana, Wyoming and Colorado, reviewed 21 wetland project submissions from the field. BLM was awarded $\$ 185,000$ to improve 15,000 acres of waterfowl production and migration habitat. 
In Montana, the Phillips Resource Area completed restoration of 38 reservoirs through challenge cost sharing with Montana Department of Fish, Wildlife and Parks Duck Stamp funds, Ducks Unlimited and the Prairie Pothole Joint Venture. The projects created 102 acres of surface water and will improve 58,000 acres of associated uplands used by waterfowl as nesting and brood rearing habitat.

In Wyoming, the Worland District finalized the Loch Katrine Habitat Management Plan. Project implementation included

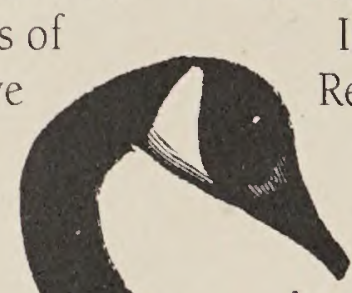

In Wyoming, the Buffalo Resource Area improved 20 acres of waterfowl habitat through dike and spillway reconstruction, along with the construction of two new brood-rearing ponds.

California's Folsom Resource Area created 500 acres of winter waterfowl habitat through innovative water management schemes, and an additional 230 acres of seasonal ponds were constructed near Sacramento, at the Cosumnes River Preserve. In February 1994, 15,000 ducks, geese and swans were using the preserve.

Alaska's Arctic District, in construction of seven waterfowl ponds and the installation of 38 nesting structures. ,

Working with the Bureau of Reclamation, a water retention dike and water control structures were constructed and water bird nesting surveys and weekly waterfowl/ shorebird population counts were conducted.

In Wyoming, the Rock Springs District completed wetland creation and enhancement plans for Wheat Creek Meadows, Cumberland Valley, Slate Creek, and McNinch Reservoir. The projects will be completed in FY 1995, improving over 32,000 acres of migration and production habitat.

Spreader dikes now create several shallow water areas for waterfowl and shorebirds in the Great Divide Resource Area in Wyoming. They provide 44 new acres of wetland habitat. The North Tipton and Red Desert No. 1 projects were designed to provide "rest stops" during fall and spring migration, and additional nesting habitat. cooperation with Ducks Unlimited, the U.S. Fish and Wildlife Service and North Slope Borough of Alaska, completed fieldwork for a LANDSAT vegetation classification of the coastal plain of the National Petroleum Reserve. The eight million acres of Arctic tundra, highly valuable for breeding and molting ducks, geese and swans, is also home to the threatened spectacled eider and candidate stellar's eider.

The Glennallen District in Alaska joined the Chugach National Forest and Ducks Unlimited in completing the field work for land cover mapping using LANDSAT Imagery of 40 townships on and near the Bering Glacier. The images are used for vegetation classification, and for monitoring future habitat change as the glacier alternately advances and retreats. Digitized maps of the area will assist in future surveys and monitoring.

In Alaska, the Kobuk District completed the final report of a fouryear field study evaluating ' waterfowl production on the Seward Peninsula, McCarth's Marsh and the Kuzitrin
Basin. Field studies were also conducted for the third year in the Pah River Flats of interior Alaska, to determine the effects of fire on waterfowl production.

In Colorado, the San Luis Resource Area received Land and Water Conservation Funds to purchase water rights for the 5,570 acre Blanca Wetlands, to ensure adequate water supplies for brood-rearing. The area produced 6,000 ducks and 400 Canada geese in 1994.

In Utah's Vernal District, the water delivery system for the 9,000 acre Pariette Wetland complex was improved to provide reliable flows for maintaining brood-rearing habitat. Two additional brood-rearing ponds were constructed in FY 1994.

In the Salt Lake District's 10,672acre Salt Wells Waterfowl Habitat Management Project, a spring source was fenced and several dikes built to create an additional 500 acres of wetlands. The Central Utah Project contributed $\$ 20,000$ to the project.

The Idaho Falls District, in cooperation with the Idaho Department of Fish and Game and Ducks Unlimited, continued improving waterfowl nesting and brood-rearing habitats along a 100-mile stretch ofthe Snake River, primarily through protective fencing of river-front tracts.

Oregon's Eugene District acquired over 300 acres containing a valuable mix of wetlands, oak savannah, and additional sites for potential wetland development, as part of the 350,000 acre West Eugene Wetlands Project.

In Washington, the Spokane District received $\$ 20,000$ in Challenge Cost Share funds for the Smick Meadows wetland restoration project from the Rocky Mountain Elk Foundation, Ducks Unlimited, Inland Northwest Wildlife Council, Pheasants Forever, E.J. White Construction Company and the U.S. Fish and Wildlife Service. Forty acres of wetlands previously drained for agriculture were restored and are 
once again being used by nesting waterfowl. Construction of Watchable Wildlife facilities are planned.

The Spokane District completed construction of the Lakeview Wetlands water pipeline, with assistance from the Inland Northwest Wildlife Council. The 3.5 mile pipeline supplies water during the waterfowl nesting and brood rearing seasons:

In Arizona, the San Simon Resource Area's Goodwin Creek wetland project continued toward meeting its planned 1998 completion date, with 300 gabions constructed for silt and water retention. Five large retention dams are also under construction, to create wetlands and ensure three miles of perennial water flows.

UPLAND GAME BIRDS

UPLAND GAME BIRDS: TO EFFECT

LONG-TERM IMPROVEMENT AND

RESTORATION OF UPLAND GAME BIRD

HABITAT ON BLM LAND.

BLM and Quail Unlimited reached an agreement that will help improve game bird habitat on public land. The agreement was developed with the assistance of the Western Fish and Wildlife Staff, and provides a 1:2 cost/benefit ratio for BLM. More than 23 species of upland game birds, including quail, grouse, ptarmigan, chukar, pheasant and wild turkey are found on BLM land. Across the nation, upland game bird populations are well below historic levels. Urbanization, industrialization and conversion of häbitat for agricultural uses have eliminated millions of acres of upland game bird habitat and degraded millions more.

Two native species, the heath hen and passenger pigeon, are extinct. Two others, Attwater's prairie-chicken and masked bobwhite quail, are now endangered and perilously close to extinction. Other species that have experienced major declines in distribution and abundance include the Columbian sharp-tailed grouse, greater and lesser prairie-chickens, sage grouse and mountain quail.

However, population losses of upland game can be reversed, as exemplified by the wild turkey. Unregulated hunting and habitat degradation reduced their number from $10,000,000$ birds to about 30,000 by the early 1900 s. Restoration work began in the 1950s and today they number over 3,000,000 birds and are increasing. Management can and does make a difference.

\section{Selected accomplishments:}

In Idaho, the Wildlife Isolated

Tracts Program continues with the Idaho Department of Fish and Game and private farmers, designed especially to enhance habitat for pheasants and gray partridge. Three BLM Districts and 55,000 acres of isolated BLM tracts surrounded by agricultural lands are involved. Various management and research Challenge Cost Share projects are underway for mountain quail, sage grouse,

Columbian sharp-tailed grouse, pheasants, chukar and wild turkey. Conservation strategies are being developed cooperatively for Columbian sharp-tailed grouse, as well as for sage grouse, throughout the Pacific Northwest. BLM is continuing funding for reintroduction of the Columbian sharp-tailed grouse into Oregon, where it had been extirpated. Cooperative research is continuing on the biólogy and status of mountain quail in eastern Oregon, where significant population declines have occurred.

The Swanson's Lake Management Plan, a cooperative effort among the Bonneville Power Administration, Washington Department of Wildlife, BLM and private landowners, provides partial mitigation for habitat losses resulting from the impoundment of Columbia River water behind Grand Coulee Dam. The 40,000-acre project area is intended primarily to promote recovery of Columbian sharp-tailed grouse.

BLM finalized an agreement with the Nevada Division of Wildlife to develop the Clan Alpine Guzzler Complex. Nineteen upland game guzzlers will be built and 30 other wildlife projects such as exclosures, protective riparian fences and springs will be maintained.

Nevada's Winnemucca District, the Nevada Chukar Foundation and Nevada Division of Wildlife are using Challenge Cost Share funds to rehabilitate a portion of the Bloody Run Mountain, after wildfires burned more than 21,000 acres. The area burned is important year-long habitat for chukar, sage grouse, gray partridge, California quail, mule deer, bobcat, mountain lion, pronghorn antelope, several Category 2 candidate species and numerous nongame species.

Twenty-nine upland game bird guzzlers were installed in four Elko Resource Area mountain ranges in northeast Nevada, in cooperation with Nevada Division of Wildlife and Nevada Chukar Foundation.

Quail Unlimited and the Fresno Sportsman's Association teamed up with BLM to benefit quail by developing a spring trough and water line at the Squaw Leap Management Area in California.

Sage grouse lek inventories conducted on 18,200 acres within the Long Valley Management Area, California, reconfirmed activity on nine leks within the management area. Similar inventories on 121,150 acres in the Bodie Hills Management Area confirmed activity on 10 leks.

In Montana, Pheasants Forever and a local rancher joined with BLM to develop pheasant nesting and winter habitat on the Woods Wildlife Area on the Wild and Scenic Missouri River in the Havre Resource Area. More than 700 acres of food plots and 250 acres of nesting and winter habitat were planted.

An obstructed irrigation drainage ditch backing water onto adjacent private property near Pompey's Pillar in Montana's Billings Resource Area 
was cleared using fire-line explosives. Historically, drag lines were used to clear the ditch, destroying pheasant and waterfowl nesting habitat and creating noxious weed problems. The new approach protected more than 300 acres of habitat and saved several thousand dollars. U.S. Forest Service smoke jumpers cooperated in the blasting project.

On the Yellowstone River's Tussler Bottom, near Miles City, Montana, over 250 acres of upland game bird habitat was improved in cooperation with the Montana Department of Fish, Wildlife and Parks.

Over 60,000 acres of habitat were surveyed in Colorado to locate and monitor strutting grounds for the Gunnison Basin sage grouse. In cooperation with the Colorado Division of Wildlife, 10,000 acres were inventoried to collect vegetation quality information for the grouse, and 20 of the birds were radio-tagged to monitor movements and habitat use.

Two hundred Gambel's quail were released in the extreme southwest corner of Colorádo as part of a cooperative reintroduction effort with Quail Unlimited and Colorado Division of Wildlife. The release marks the beginning of a long-term effort to restore quail to public land.

In a cooperative inventory and monitoring effort with the Idaho Department of Fish and Game, 230,000 acres of Idaho's Burley District were aerially surveyed for sage grouse leks, with locations recorded using Global Positioning System technology. In a cooperative ground survey to locate Columbian sharp-tailed grouse leks, 115,000 acres were surveyed and 21 new leks were found.

Over 49,000 acres of potential sage grouse lek sites and nesting habitat were inventoried in Wyoming's Worland District, with volunteers contributing more than

\section{.

.

100 hours. In another, collaborative effort BLM, two local volunteers and the Wyoming Game and Fish Department monitored trends in sage grouse populations and activities on 125 known lek's.

Wyoming's Rawlins District completed aerial surveys for sage grouse on 500,000 acres of potential habitat, in response to energy development proposals. There has been an overall downward trend in sage grouse populations in the District over the last several years, and only seven active leks were located.

The Rock Springs District inventoried and monitored 80,000 acres of sage grouse breeding complexes in cooperation with the Wyoming Game and Fish Department. As a result of the surveys, five new leks were located near Granger and Little America. In the Platte River Resource Area, 400,000 acres were inventoried and 57 leks monitored.

A blue grouse habitat inventory was conducted on Billy Creek in Casper District's Buffalo Resource Area, Wyoming. Wild turkey nesting in the area was also documented for the first time.$$
\text { (n) }
$$$$
\text { . }
$$$$
\text { ( }
$$$$
\begin{aligned}
& \text { NEOTROPICAL MIGRATORY BIRDS } \\
& \text { AND OTHER NONGAME BIRDS }
\end{aligned}
$$

NEOTROPICAL MIGRATORY BIRDS AND

OTHER NONGAME BIRDS:

TO MAINTAIN STABLE POPULATIONS

AND RESTORE DECLINING

POPULATIONS OF BIRDS BY HELPING

DETERMINE THE CAUSES

FOR DECLINES, FOCUSING ON

IMPROVED HABITAT MANAGEMENT,

AND DEVELOPING ECOSYSTEM-LEVEL

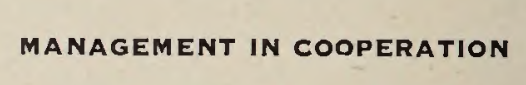

WITH LOCAL, NATIONAL AND

\section{INTERNATIONAL PARTNERS.}

BLM has been diligently working to achieve the goals and objectives outlined in Partners In Flight, a joint initiative among Canada, the U.S., Mexico, the Caribbean, Central America and South America, to coordinate conservation activities on behalf of birds that breed in North America and spend their winters in New World tropics. By the end of FY 1994, nearly every state agency and every major conservation organization in the Western Hemisphere were actively taking part in this unprecedented conservation effort.

\section{Selected Accomplishments:}

Ten breeding bird counts were established and surveyed along three riparian areas as part of a region-wide, long-term monitoring study in Washington. Inventories were conducted to determine what percentage of the breeding bird community consists of neotropical migrants. A bird guide to the Channeled Scablands is being produced. Four Monitoring Avian Productivity and Survivorship stations were set up, and BLM employees are 
training Audubon members to assume future responsibility for operating a station. Fifty-one permanent transects were established.

The Oregon State Office conducted a one-week field training session on audio and visual bird identification and point count survey protocol for nongame birds.

The Nevada Division of Wildlife and BLM Elko District conducted bird surveys within the Mary's River riparian zone, to track species abundance and diversity during riparian area recovery. In 1986, 47 species were found in the area. By 1994 , 90 species were using the same area.

Three neotropical migratory bird transects were surveyed for the fourth year in a row along Dixie Creek, Nevada, to determine bird response to improvement in stream and riparian habitat conditions. About five miles of Dixie Creek has been rested from grazing since 1990 . In Oregon, the High Desert Ecological Research Institute established point count transects in Vale, Burns, Prineville, and Lakeview districts, to begin developing a foundation for the database of birds using the riparian zones of eastern Oregon.

Oregon BLM initiated a multiorganization agreement to design, plan and implement inventory and monitoring programs for neotropical migrants and their habitats on federal, state and participating private lands in Oregon and Washington.

The programs will serve as a model for systems implemented at regional scales in the West.

The Roseburg District, Oregon!' continues to run one Monitoring Avian Productivity and Survivorship station. The Spokane District supports one station in Douglas Creek.

Oregon BLM completed the South-Coast Birding Guide, identifying keý birding areaș along the Oregon coast.

Three of Idaho's six districts have completed field checklists of birds. A fourth has a draft ready for printing, and the other two districts are developing checklists.
Arizona is compiling a statewide Breeding Bird Atlas, with the Arizona Game and Fish Department helping to fund the effort. Breeding Bird Surveys are being conducted on 14 million acres of public land, with BLM biologists serving as regional coordinators in four areas of the state.

In Arizona, bird population data were gathered from the San Pedro National Conservation Area, the Empire-Cienega watershed, and the Muleshoe Cooperative Management Area.

Three Breeding Bird Surveys are being conducted in the Kingman Resource Area, Arizona

In Arizona's Dos Cabezas Mountains, a 10-square mile area has been inventoried the last two years as a part of the Arizona Breeding Bird Atlas Project. Over 100 species of birds have been recorded in this unit. Next year the inventory is planned for two more areas.

Two hundred cottonwood poles, 100 willow poles, and 250 mesquite trees were planted at several sites along the Lower Colorado River and Lake Havasu, Arizona, to continue riparian restoration efforts that began almost 10 years ago. Invading salt-cedar and arrowweed were removed from a 15 -acre site planted four years ago. The projects are restoring important native habitat for breeding and migratory birds that once lined much of the Lower Colorado.

Biologists in Arizona's Lake Havasu Resource Area continued monitoring Heron Island, an historic heron rookery on Lake Havasu, and made needed repairs to artificial nesting sites on the island. Six pairs of herons successfully fledged young from the nests in 1994.

The Shivwits Resource Area in Arizona inventoried 15,000 acres for breeding birds as a part of the Arizona Breeding Bird Atlas, and surveyed 120 acres of suitable Southwest willow flycatcher habitat.

In the proposed Inimim Forest Area of Critical Environmental Concern, a bird banding project was begun by local residents in cooperation with BLM and Point Reyes Bird Observatory to monitor neotropical migratory birds. The Point Reyes Observatory, which has a higher elevation banding station, will use the data in conjunction with the neotropical birds activities at lower elevations.

In Nevada's Elko District, 12 miles of streamside habitat were inventoried for willow flycatchers and other breeding birds.

Wyoming's Casper District published Checklist - Birds of Northeastern Wyoming, covering ten counties in the state.

In California, three Breeding Bird Surveys were completed on the Carrizo Plain Natural Area and Sierra Nevada Foothills, covering 19,000 acres. A shorebird survey was completed in the San Joaquin Valley.

BLM and U.S. Forest Service are inventorying and monitoring populations of neotropical migratory birds on the South Fork of the Snake River in Idaho.

In cooperation with Cornell University, Montana's Garnet Resource Area gathered data on 30 western tanager plots for Project Tanager. The plots were visited twice, once during breeding and once during nesting, to' document breeding success in patches of habitat smaller than 25 acres.

Utah's Cedar City District completed six Breeding Bird Survey routes and monitored about 26,000 acres of nongame bird habitat.

In Utah's Vernal District, BLM completed a Project Tanager study in cooperation with Cornell University, to determine the presence and status of the western tanager in the district. A BLM volunteer found two breeding pairs and made numerous sightings using tape-recorded tanager calls.

Montana's Butte District, in conjunction with the Deerlodge National Forest, produced bookmarks celebrating the Second Annual Migratory Bird Day. The bookmarks list Tips to Birdwatching and provide an effective year-round reminder about the annual event. 
Implementation of the Colorado Neotropical Migratory Bird plan is well underway, with neotropical bird surveys and transects now established in priority habitats across all four BLM districts (pinon-juniper, sagebrush, riparian). BLM conducted Breeding Bird Surveys and also contributed funds to hire an inventory crew to survey numerous Breeding Bird Atlas blocks.

A Project Tanager study was initiated in Idaho's Deep Creek Mountains, in cooperation with the Portneuf Audubon Society and Idaho State University. Four locations are being inventoried.

The Rawlins District, Wyoming, prepared and printed 5,000 copies of a bird checklist of the Great Divide Resource Area.

Over 16,000 acres along three 25-mile Breeding Bird Survey routes were inventoried for breeding birds and migrants in the Worland District, Wyoming, in cooperation with the U.S. Fish and Wildlife Service.

Wyoming's Platte River Resource Area biologists conducted breeding bird counts on over 60,000 acres in 11 different habitat types in the south Bighorn Mountains. The surveys documented at least 50 different breeding bird species.

An updated Field Checklist of the Birds of Utah was published in cooperation with the Utah Ornithological Society, U.S. Forest Service, National Park Service, Utah Division of Wildlife Resources and Utah Division of Parks and Recreation.

The list includes 392 species accepted by the Utah Ornithological Society's Bird Records Committee through 1993.
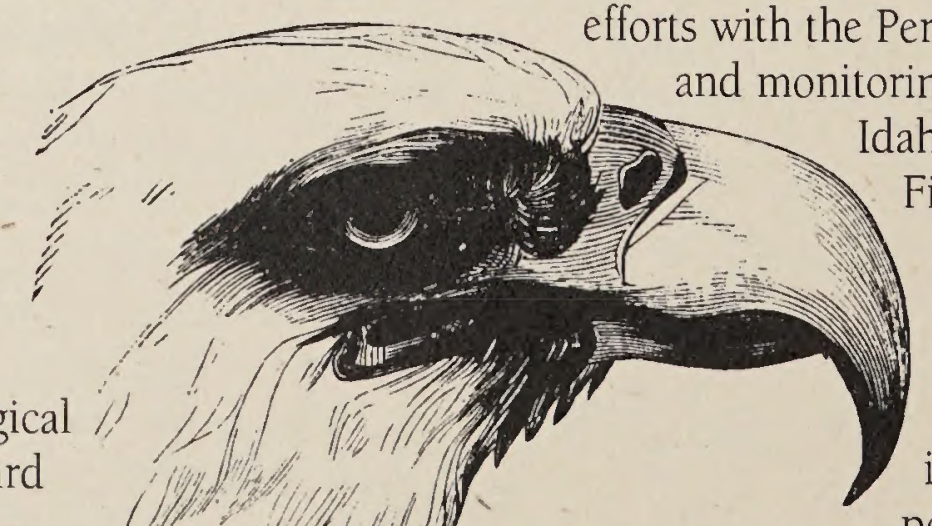
Department of cal food chain, many birds of prey species continue to receive special status because of threats to their existence. Raptor conservation is a major BLM responsibility because an unusually large number and variety of these avian predators reside, winter or pass through BLM habitats.

\section{Selected Accomplishments:}

Idaho supports peregrine falcon recovery through cooperative efforts with the Peregrine Fund,.Inc., and monitoring birds with the Fish and Game. BLM is continuing to fund the cooperative study on sources and impacts of lead poișoning in bald and golden eagles in southcentral valleys. The Raptor Research and Technical Assistance Center remains a close cooperator in the Snake River
Birds of Prey National Conservation Area, and elsewhere. An Idaho Technical Bulletin was produced on raptor resources of the lower Salmon River Drainage.

The Tonopah Resource Area, Nevada, conducted inventories on 400,000 acres of ferruginous hawk habitat, and 5,000 acres of northern goshawk habitat. An additional 486,000 acres of raptor nest inventory was conducted with 70 nests revisited and 45 new nest sites discovered.

The annual raptor count of the largest known fall migration of birds of prey in the inland western U.S. was completed along Nevada's Goshute Mountains. The count, conducted by Hawkwatch International in cooperation with Elko District, was completed with volunteer birding enthusiasts contributing almost 10,000 hours in the elevenweek count and bird banding project.

Oregon BLM completed raptor inventories on about 217,000 acres. Ten new ferruginous hawk nests and six new burrowing owl nests were located.

Over 64,000 acres of raptor habitat were monitored in the Dillon Resource Area, Montana.

The ninth annual gray hawk survey on the San Pedro River, Arizona, was conducted in June and early July. More than 20 nests were located this year, with good nestling survival. The San Pedro Ecosystem is estimated to support 75 percent of the United States population of gray hawks, 40 percent of which inhabit the San Pedro National Riparian Conservation Area.

The Shivwits Resource Area in Arizona removed six miles of oldstyle, raptor-killing powerline poles and replaced them with raptor-safe poles, in cooperation with the local rural electric company.

Utah'ș Salt Lake District volunteers assisted with investigating raptor mortality in PVC pipe used for marking mining claims, inventorying 3,500 acres in the Pilot Mountains. 
Actions are underway to remove the markers and prevent future use of open-ended PVC pipe for claim makers on public land.

In Colorado, Grand Junction High School students built and installed 50 owl nest boxes in cooperation with BLM's Grand Junction District. Students will monitor use of the boxes. The partnership expanded to include the local Audubon Society, whose members built and installed an additional 20 boxes.

Mid-winter bald eagle surveys were conducted on 10 miles of the Snake River below American Falls Dam, and on a 131-mile route through the Raft River Valley and on the Snake River in the Burley, Idaho, District. Sixty-three ferruginous hawk nests were monitored on 170,000 acres.

Wyoming volunteers contributed over 700 hours to help conduct surveys and inventories on 16,000 acres of Worland District raptor nesting habitat and during the annual mid-winter bald eagle survey, conducted on 126,000 acres.

In Wyoming, about 200 previously unknown raptor nests, both active and inactive, were discovered during the Rawlins District inventory of five known raptor concentration areas. About 832,000 acres are within the five areas.

\section{TERRESTRIAL HABITAT MANAGEMENT}

MOUNTAIN SHEEP

MOUNTAIN SHEEP:

TO MANAGE ECOSYSTEMS

TO SUPPORT VIABLE POPULATIONS,

OR METAPOPULATIONS,

FOR THE FOUR SUB-SPECIES

OF MOUNTAIN SHEEP FOUND
Bighorn sheep are among the most spectacular of big game animals. Conservation organizations that are especially interested in bighorns have been among BLM's most enduring partners in providing ideas, funding and enthusiasm for these magnificent animals.

Selected Accomplishments: BLM established an Interagency Mountain Sheep Ecosystem Management Team for updating and expanding the existing Desert Bighorn Sheep Habitat Management plan, to include management of California bighorn sheep, Rocky Mountain bighorn sheep, and Dall sheep. The new plan, Mountain Sheep Ecosystem Management on Public Lands, A Strategy for the Future, establishes management actions and activities at more specific levels than those in Fish and Wildlife 2000. The plan is expected to be published early in FY 1995.

A partnership project with the Foundation for North American Wild Sheep was initiated to build a water development as part of the Foundation's annual conference, to be held in Phoenix in 1995.

Two poorly functioning desert bighorn sheep water projects in the Lower Gila Resource Area were reconstructed in cooperation with the Arizona Game and Fish Department and Arizona Desert Bighorn Sheep Society. One new development was also constructed.

In January 1994, BLM's Winnemucca District, the Nevada Division of Wildlife and Oregon Department of Fish and Wildlife transplanted 20
California bighorns from Oregon's Hart Mountain to Nevada's Montana Range.

The Winnemucca District, in cooperation with the Nevada Division of Wildlife, transplanted 18 Califomia bighorns from the Paradise-Denio Resource Area to the Calico Mountains, in the Sonoma-Gerlach

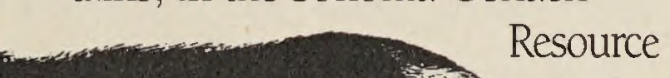
(nece trea

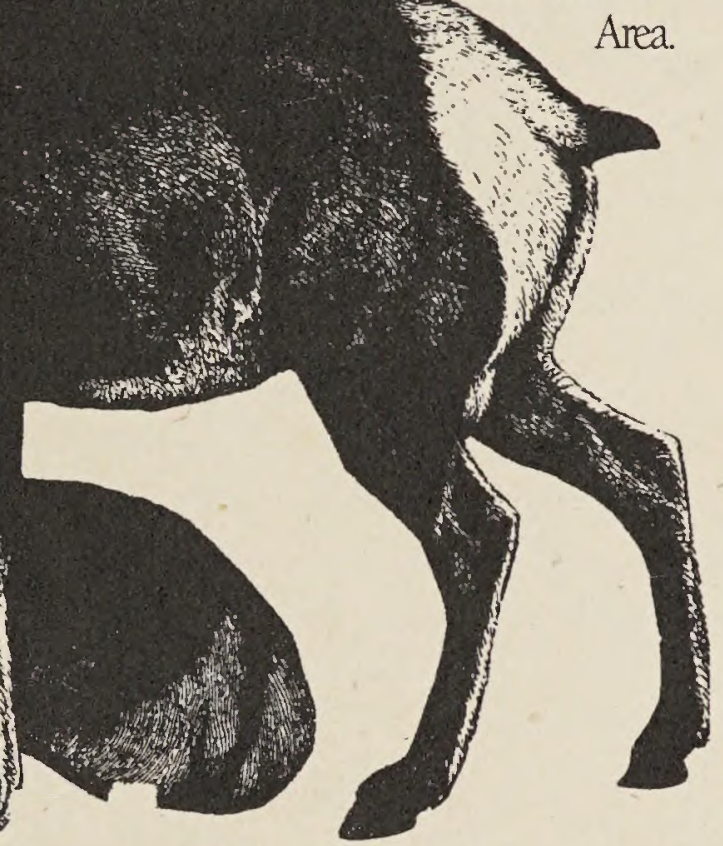

Over 630,000 acres of habitat for 'Peninsular Ranges bighorn were inventoried. The metapopulation is listed by California as threatened, and is proposed for federal listing. Elsewhere in the desert, over 50 big game guzzlers were maintained and operated by volunteers from several organizations.

Montana's Headwaters Resource Area, in cooperation with the Montana Department of Fish, Wildlife and Parks, has finalized the Sleeping Giant Bighorn Sheep Reintroduction Habitat Management Plan, and 68 Rocky Mountain bighorns have been released in the Sleeping Giant Wilderness Study Area since December 1993. The bighorns have settled throughout the project area and are reproducing successfully.

In Wyoming's Lander Resource Area, BLM and The Nature Conservancy are working to acquire up to 2,500 acres of bighorn winter range. The nation's largest Rocky Mountain bighorn herd resides on nearby public land and the acquisitions will help ensure the herd's long-term survival. 


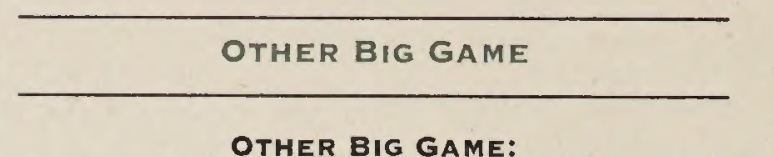

TO ENSURE THAT BIG GAME SPECIES

ON THE PUBLIC LAND

ARE PROVIDED HABITAT OF

SUFFICIENT QUANTITY AND QUALITY

TO SUSTAIN IDENTIFIABLE

ECONOMIC AND/OR

SOCIAL CONTRIBUTIONS

TO THE AMERICAN PEOPLE.

Big game provide enjoyment to wildlife viewers and a challenge to hunters. They are also the backbone of many rural economies. In places, BLM's success in management is linked directly to the health of big game populations by much of the public. For these reasons and more, BLM and its partners work hard to maintain healthy big game populations through good habitat management.

\section{Selected Accomplishments:}

The Rocky Mountain Elk Foundation and a private landowner contributed funds to help enable a land exchange involving 3,100 acres in north-central Colorado, near Service Berry Mountain. The exchange blocked up crucial deer and elk winter range, and helped resolve public access issues. Four miles of perennial stream and associated riparian habitat were acquired in the exchange.

In Idaho's Shoshone District, 400 acres of deer and elk winter range was planted with bitterbrush and "Hobble Creek" sagebrush to reestablish winter browse.

The Rocky Mountain Elk Foundation purchased materials for wildlife watering systems in the Idaho Falls District, to meet elk needs in the Sands Habitat Management Plan area. The district's role is to complete site design and installation of the 3,000 gallon systems.
One elk guzzler/aspen water harvester was installed in Idaho's Burley District and two others are planned for installation in early FY 1995, in cooperation with the Rocky Mountain Elk Foundation and Idaho Department of Fish and Game. One will be placed on private land in cooperation with a local rancher, to help solve a depredation problem.

In Wyoming, the Worland District planted 200 aspen for elk habitat improvement under the Rattlesnake Habitat Management Plan, and 20 acres of aspen/conifer mixed woodland sites were clearcut to promote aspen regeneration for elk and mule deer.

Planning for elk will have a regional flavor, thanks to the efforts of a group of people who worked on a planning amendment to the Wells Resource Management Plan. Elk management decisions could affect public and private land in a three-state area (Utah, Idaho and Nevada); the work of the group will help the continuity of those decisions. BLM, U.S. Forest Service, county government, interest groups, private landowners and wildlife agencies from the three states assisted with the amendment.

In Nevada's Elko Resource Area, 1,000 acres of annual vegetation was seeded to perennials, to restore mule deer winter habitat.

In Wyoming, the Rawlins District improved 20 acres of elk calving habitat by a road rehabilitation project, and continuing seasonal road closures. In addition, 2,900 acres of recently burned fall/winter deer habitat were replanted with bitterbush seedlings.

Near Cretaceous Mountain in Wyoming's Big Piney-LaBarge enhancement area, 2,500 acres of mule deer and elk winter range were improved through prescribed burning. The Rocky Mountain Elk Foundation aided in funding the project, and Mobile Oil Company is providing a range rider for two years to herd livestock off the burned areas.
To better manage riparian areas, interdisciplinary teams are analyzing data gathered from vegetation transects within crucial big game winter ranges and from stream surveys in all Wyoming districts. In the Rock Springs District, alone, 70,000 acres of winter range and 50 miles of stream were surveyed.

In cooperation with the Rocky Mountain Elk Foundation, Colorado's Montrose District "roller chopped" 300 acres of pinon juniper habitat to benefit wintering elk and reseeded 200 acres of habitat denuded by fire.

In Colorado, the Grand Junction District began a three-year study in Skim Milk Basin to measure deer and elk response to controlled burning on 600 acres within a scrub oak community. The study is being conducted in cooperation with Colorado State University, Colorado Division of Wildlife, U.S. Forest Service, Rocky Mountain Elk Foundation and the Colorado Land Board.

In New Mexico, a Farmington District Challenge Cost Share project with Amoco Oil is funding riparian habitat improvement projects. In one phase of the project, potholes were blasted to provide additional water for big game in a high-use area.

Utah biologists from the Vernal District, Brigham Young University, and Utah Division of Wildlife Resources completed the fourth year of a five-year cooperative black bear study, to determine habitat areas and population trends on 50,000 acres of the Book Cliffs. Over 50 bears have been captured, analyzed, tagged and released in the study.

The Cedar City District in Utah, assisted by prison crews, cut down invading pinyon and juniper trees on 400 acres of crucial mule deer winter range. The removal will enable the rejuvenation of more desirable winter browse plants.

Thirteen water catchments were constructed for big game in Utah's Cedar City, Vernal, Moab and Richfield Districts. The new water sites will expand big game habitat 
about 25,000 to 30,000 acres by providing reliable, year-round water. Arizona's Phoenix Resource Area completed a prescribed burn plan for 42,000 acres of grassland, to improve pronghorn antelope habitat.

Research to determine why antelope aren't thriving in the Railroad Wash Watershed Area is being conducted by BLM's San Simon Resource Area, Arizona Game and Fish Department, New Mexico Game and Fish, University of Arizona Extension Service, Center for Holistic Resource Management and a local livestock permittee. The threeyear project began in 1993, because of population problems since the animals' reintroduction to

the area in 1986.

In Oregon, the Medford District improved deer and elk winter range by barricading or decommissioning 50 miles of roads, fencing five springs to exclude livestock and conducting prescribed burning on over 100 acres to improve forage.

Seven energy companies, BLM Rock Springs District, Wyoming Game and Fish Department, private landowners and U.S. Fish and Wildlife Service are developing plans to improve crucial pronghorn winter range in an area being developed for energy. In the Challenge Cost Share effort, vegetation inventory and evaluation on 100,000 acres have been completed as part of the Moxa Arch Pronghorn Habitat/Livestock Forage Mitigation Project.

\section{AMPHIBIANS AND REPTILES}

Amphibians are closely linked to aquatic and moist upland ecosystems, and especially sensitive to water quality in their surroundings. They are one of the best indicators of an area's environmental quality. But, aside from amphibian and reptile species that are threatened, endangered or candidates for listing, little attention has been given to these groups, particularly on BLM public lands because of limited funding, personnel and "other" workloads.
Recent concern over global declines of amphibians and the disappearance of entire populations in the West has abruptly brought them attention. Unfortunately, other agencies and institutions are in little better position to understand what is happenning to amphibian populations. There simply never has been enough interest in these species to gain even basic biological data. As shown below, these groups are finally beginning to get some long overdue regard.

\section{Selected Accomplishments:}

Challenge Cost Share projects in Idaho included several general amphibian and reptile inventories, rare snake inventories and spotted frog inventories. The latter two inventories will be used to develop Conservation Agreements to reduce threats and the need for federal listing.

\section{BLM, U.S. Forest Service,} and Oregon Department of Fish and Wildlife co-sponsored six joint amphibian identification training sessions, with over 300 field staff from Oregon and Washington participating. The agencies are also developing a field identification manual and a booklet for surveying and monitoring methods.

In a project that may offer an alternative to spraying for mosquitoes around Rawlins, Wyoming, ten bat houses were placed in two locations to encourage bat roosting. Spraying is a threat to the endangered Wyoming toad, and bats can eat up to 600 mosquitoes per hour. An agreement to build and place more bat houses is being developed with the city of Laramie.

\section{Bonita Creek, Markham}

Creek, Aravaipa Creek, Big Spring and other small springs in southeastern Arizona were monitored for lowland leopard frogs by the Gila Resource Area. Amphibian inventories documented

candidate species in 23 different creeks within the San Joaquin Valley and South Central Coast bio-regions in California. Key candidate species for federal listing as threatened or endangered are the southwestern pond turtle, yellow-legged frog, and two-striped garter snake. The first red-legged frog population on BLM land in the Bakersfield District was -documented in the San Joaquin Valley bio-region.

Inventories of reptiles, amphibians and small mammals were completed on 2,000 acres acquired by the Utah Division of Wildlife Resources and BLM.

\section{BATS}

Bats often play critical roles in western ecosystems but are also not well understood. Their nocturnal behavior, inaccessible breeding and roosting sites, and migratory behavior make them difficult to study. As a result, we know little of their basic ecology or needs. Because bats often use human dwellings, bridges and mine shafts, there is an opportunity for BLM to protect this diverse and fascinating group of mammals.

\section{Selected Accomplishments:}

The Ely District has taken the lead in Nevada in inventorying abandoned mines for bats. Working with - BLM and Bat Conservation International, local and national volunteers spent 220 hours inspecting 31 mines in the district that were scheduled to 
be closed for safety considerations.

Nine mines were occupied by bats and another 14 were rated as suitable habitat.

BLM biologists and cooperators in Idaho are using mist-nets to inventory bats in and around numerous caves, mines, and canyons. Bat Conservation International is helping design safety gates that stop human access to abandoned mines, but allow bats to pass through. In addition, the Shoshone District inventoried 15 caves for winter hibernacula. Conservation Agreements are being developed for the Townsend's bigeared bat and spotted bat, both Category 2 species.

In Oregon, biologists initiated bat surveys using the Anabat II monitoring device. BLM developed a method to identify local bats using the detectors and developed a reference catalog of calls. BLM is also mist netting small ponds at night, and conducting day searches of bridges and other likely roost sites for bats. All three special status species have been found, with better than expected numbers in some locations. A cooperative agreement to gate and maintain caves used by bats was initiated, and protective gates were installed on four caves.

Wyoming's Cody Resource Area inventoried 500 acres of likely bat habitat and identified potential roosting caves on Little Mountain. A bat-gate was installed on an abandoned coal mine in the Washakie Resource Area.

Working with ASARCO Inc., potential bat roost sites were inventoried on about 4,500 acres of BLM lands in the Phoenix Resource Area.

With a Heritage Grant from the Arizona Game and Fish Department, the Tucson Resource Area began surveying abandoned mines for bats, including federal- and state-listed species. The Abandoned MineFinders, a volunteer group, provided 2,500 hours of assistance in locating mines to be surveyed.
Tucson Resource Area biologists. assisted with light-tagging and radiotelemetry studies of the federally endangered lesser long-nosed bat.

In Arizona, the AZCO Mine in Sanchez donated $\$ 2,500$ for bat habitat mitigation.

In Arizona's Kingman Resource Area, a bat-gate was installed on a hazardous mine that is a winter home to about 2,000 California leaf-nosed bats, their largest known winter roost. The mine also supports a large maternity colony of Yuma myotis bats during the summer.

The Havasu Resource Area was awarded an Arizona Game and Fish Department Heritage Fund Grant to survey bats over 18 months along the Bill Williams River. The $\$ 21,000+$ grant was used to contract with a professional bat researcher. One BLM biologist assisted with the bat survey during the first field season, locating four federal candidate bat species.

In Utah's Cedar City District, spotted bats were located at two of five sites surveyed during inventories conducted under a Challenge Cost Share agreement. In the Richfield District, spotted bat surveys were conducted but no bats were confirmed.

\section{OTHER SPECIES}

More and more, BLM is recognizing that the "parts", of ecosystems need attention. Invertebrates are one part that has been overlooked too often in the past, sometimes only gaining recognition when they were deemed pests or categorized as a special status because of plummeting populations. Now, they are being recognized as important links to the overall health of the land, and serve as indicators of general conditions. As ecosystem management is established, BLM will improve management of these "other species" and continue to learn more about them, what they can tell us, and the niches they fill.

\section{Selected Accomplishments:}

Uncompahgre fritillary butterfly studies were completed on 350 acres in Colorado. In cooperation with the U.S. Forest Service, contractors resurveyed 20 acres of the species type localities, and 12 known snow willow sites for the presence of the species.

Unaweep Seep Natural Area, Colorado, was burned this year to improve habitat for the federally listed Great Basin silverspot butterfly.

The Jackson District, Mississippi, and Fort Chaffee, Arkansas, have an interagency agreement and funding to continue monitoring the American burying beetle on the fort.

A Technical Note on Idaho dunes tiger beetle inventories was published and a conservation agreement for the beetle is in preparation.

A cooperative cost-share project with The Nature Conservancy to conduct baseline inventories of small mammals in each landscape ecosystem in Wyoming's Buffalo Resource Area was completed in 1994. Wyoming's Casper District conducted smallmammal inventories on 60,000 acres . in 11 different habitat types in the south Bighorn Mountains. 


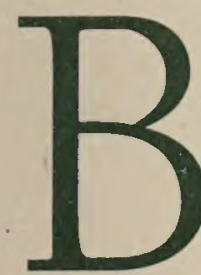

LM manages 169,000 miles of stream and riparian habitat; 2.4 million acres of lakes; and 173,000 acres of reservoirs. Most of the streams and lakes are in Alaska. In California, Orèon, Washington, and Idaho, BLM manages about 2,100 miles of anadromous fish stream over 600 miles of stream historically occupied by anadromous fish; and another 12,600 miles influencing conditions in anadromous streams. These streams are located in 95 different watersheds containing at least 173 known stocks of anadromous salmon, steelhead, and sea-run trout that are at a moderate to high risk of extinction.

In the Intermountain West, BLM waters are home to more than a dozen distinct forms of native trouts. The southwest deserts contain a diverse array of desert ponds and springs harboring many unique fish species adapted to live in these harsh environments.

Some progress has been made in implementing the Anadromous Fish and Fisheries Habitat Management Strategy Plans. The Special Status Fishes Management Strategy Plan, completed in 1992, is in the beginning phases of implementation. Many miles of stream and associated riparian habitat have been treated to improve fish production, especially in watersheds containing federally listed species and streams containing fish at high risk of extinction.

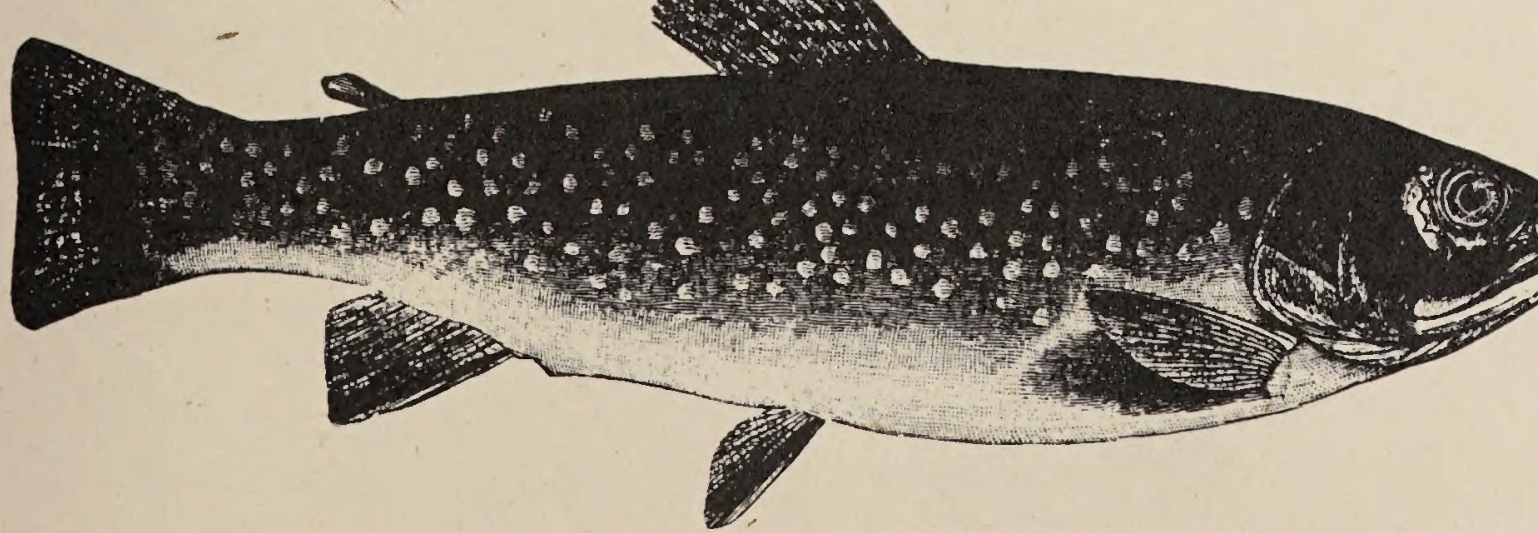

ANADROMOUS'FISH HABITAT

ANADROMOUS FISH HABITAT:

TO CONSERVE AND RESTORE STOCKS

OF PACIFIC SALMON AND

ANADROMOUS TROUT ON

BLM LAND OF THE WESTERN

UNITED STATES. MORE SPECIFICALLY,

MAINTAIN THE QUANTITY,

QUALITY, DIVERSITY, AND

COMPLEXITY OF FISH HABITATS

NEEDED TO CONSERVE

AND RESTORE ALL REMAINING

STOCKS OF WESTERN ANADROMOUS

SALMONIDS ON LANDS

MANAGED BY BLM.

The Anadromous Fish Habitat Management Plan is being revised, updated, and tiered to development of three specific regional initiatives: Columbia Basin, Coastal, and Alaska. These three distinct anadromous fish regions require somewhat different strategies to manage habitats and species.

\section{COLUMBIA INITIATIVE}

In eastern Oregon and Washington, the four districts completed inventories on 30 miles of stream to determine existing stream and riparian habitat condition. Habitat improvement projects, including instream structures and planting willow trees to curb bank erosion, were completed on four streams. Two miles of fencing were constructed to exclude livestock grazing in riparian areas along the Grande Ronde River, to protect federally listed chinook salmon.

Idaho BLM is heavily involved in anadromous fish work, especially since the listing of the Snake River sockeye, fall chinook, and springsummer chinook salmon as endangered and threatened. The Salmon and Coeur d'Alene Districts and Idaho State Office have major work loads related to consultation with the National Marine Fisheries Service, performing inventory, evaluations, monitoring and studies tied to biological evaluations and the Columbia Initiative. A review of the status of steelhead trout in the upper Columbia River is underway to determine if it should be listed.

Idaho's Challis Resource Area is monitoring all uses of all riparian and upland habitat that may affect critical habitats in 25 key areas, and initiating a riparian inventory following the Montana Riparian Association process on 135 miles of streams.

Watershed and ecosystem plans have been initiated for the Pahsimeroi River, East Fork Salmon River and Main Salmon River.

COASTAL INITIATIVE

In western Oregon, the five coastal districts inventoried about 210 miles of stream to determine stream and riparian habitat condition. Macroinvertebrate sites (192) were sampled and sent to the lab in Logan, Utah for analysis. Three instream restoration projects were completed 
along a half mile of stream and three culverts were replaced with bottomless arches to allow anadromous fish passage. Restoration was completed on 100 acres of dense red alder riparian habitat to reestablish conifers for potential sources of large woody debris. About 30 miles of roads were decommissioned and 3.5 miles of road resurfaced to reduce the possibility of excessive sediments washing into streams used by anadromous fish.

An Umpqua Basin Fisheries Restoration Initiative was formed by the Douglas County Water Resources Board, which includes BLM, U.S. Forest Service, Oregon Department of Fish and Wildlife, Pacific Power and Light, Umpqua Fishermen and Steamboaters, and private industry (Roseburg Resources, Weyerhaeuser, Seneca, Lone Rock, and International . Paper). In support of the initiative, BLM's Roseburg District conducted stream and spawning surveys, habitat restoration work and water quality monitoring. The goal is to recover anadromous stocks found in the basin and prevent further listing of stocks. Recently, the National Marine Fisheries Service proposed listing as endangered the cutthroat trout in the Umpqua Basin.

Alaska inftiative

The Alaska State Office completed the first year of development of the Alaska Aquatic Resources Information Management System, which included preparation of the Statement of Need, Charter, Project Plan and development of a draft model. The project offers a comprehensive data management system for all forms of aquatic data, and is expandable to include other resources data. The system is being reviewed for use on a national scale.

The Anchorage District conducted an instream flow study on the Unalakleet River, a designated wild and scenic river. To determine mean monthly flows to protect the wild and scenic values, the U.S. Fish and Wildlife Service Instream Flow Incremental Methodology was used. The district also is coordinating with the Landscape Ecology Modeling and Analysis Center in Logan, Utah, to automate color infrared aerial photography of the Unalakleet River. These data will complement the instream flow study by providing riparian and fisheries habitat data.

The Glennallen District completed the field portion of a threeyear Challenge Cost Share project with the University of Alaska Fairbanks to determine the ecological requirements of steelhead on the Gulkana River, the northernmost run in the U.S. The research will provide the district with information for management of this declining steelhead/ rainbow fishery.

The Kobuk District completed plans for management of the Hogatza River and Indian River Areas of Critical.Environmental Concern. These areas are important for chum salmon production, and have potential for placer gold mining. Field work conducted in the Hogatza area by a team of specialists inventoried 17 miles of Clear Creek and collected water quality and macroinvertebrate samples to collect baseline data in anticipation of mining activities.

\section{RESIDENT FISH HABITAT} MANAGEMENT

Resident fish species include all those not classified as anadromous or special status. Emphasis is to manage for the biological integrity of aquatic ecosystems and associated watersheds to provide economic and recreational benefits to the public. Improved habitat for these fishes is allied to objectives of the RiparianWetland Initiative, Partners In Flight and amphibian conservation, and clearly an integral part of ecosystem management strategies.
Selected accomplishments:

General resident fish work in Idaho entails cooperative recreation program initiatives such as providing barrier-free fishing access, environmental education and free fishing day. Work with native fishes is focused on inventories and monitoring, Bring Back the Natives efforts, and riparian enhancement projects. Conservation Agreement progress is underway for candidate and sensitive species, including bull trout, cutthroat trout (Bonneville, westslope, fine-spotted, and Yellowstone) and redband trout.

Idaho's Lemhi Resource Area won the 1993 American Fisheries Society's Riparian Challenge award. Almost 30 miles of stream improved significantly, through improvements in livestock management. Enforcing grazing regulations, removing livestock early because of drought, reducing the number of cattle in allotments and use of small streamimprovement structures all contributed to stream quality improvements.

In cooperation with Wyoming Game and Fish Department, the Worland District stocked trout in an abandoned open pit mine that was rebuilt to create a wetland complex. About 300 Christmas trees were bundled, weighted, and placed in Wardel Reservoir to provide cover for warmwater fish.

The third year of the four-year, multi-state Virgin River Instream Flow Study was completed in Utah. Baseline information was collected on hydrology, vegetation and habitat for the endangered woundfin minnow and Virgin River chub.

In Arizona, the first two completed projects of the Lake Havasu Fisheries Improvement Program were dedicated on February 15, 1994. Secretary of the Interior Bruce Babbitt, Assistant Secretary Bob Armstrong, BLM Director Mike Dombeck, representatives of the seven partner agencies and organizations and local community officials participated in the opening of sites at Havasu Springs and Take-Off Point. The sites are part 
of a 10-year, multi-million dollar project to provide a fully accessible floating fishing dock, fishing platforms, parking areas and trails to improve shoreline fishing access at Lake Havasu. Partners in the program are BLM, Anglers United, Bureau of Reclamation, U.S. Fish and Wildlife Service, Arizona Game and Fish Department, California Department of Fish and Game and Metropolitan Water District of Southern California:

The Bill Williams River Corridor Technical Committee, an interagency committee composed of four federal and three state agencies, prepared water release recommendations to manage flows from Alamo Dam. The changes will improve both recreational fishing and boating opportunities at Alamo Lake and also benefit riparian habitat, wilderness values, and native fisheries along the 36-mile Bill Williams River downstream.

In Arizona, the Lake Havasu Fisheries Improvement Program installed over 8,000 habitat structures in the lake in 1994. Two staging areas were developed along the shore, where volunteers construct habitat structures that are then transported to target coves and sunk into the lake. To date, over $\$ 700,000$ in materials and labor has been contributed. With less than three miles of fence, a riparian pasture encompassing more than 30 miles of high priority threatened Lahontan cutthroat trout habitat was constructed in 1994. A combination of rest, reduced hotseason use, changes in livestock class, riding, and other means will be used to improve stream and riparian habitat conditions within the Beaver Creek Watershed. The project was initiated by Elko Resource Area in cooperation with Western States Minerals and Nevada Mining Association.

Implementation of the Mary's

River Master Plan continued, an ecosystem effort with emphasis on recovery of the threatened Lahontan cutthroat trout. Work completed by Nevada's Elko District in 1994 'included processing the Mary's River
Land Exchange, Carlson Field Fence construction, Upper Mary's River riparian planting project, staff gauge installation on Marýs River and tributaries, fish population inventory, seedling survival monitoring, vegetation transects, macroinvertebrate sampling, water quality sampling, Chimney Creek trend study, breeding and migratory bird surveys.

At the Colorado River Nature Center, an area cooperatively managed by BLM, Arizona Game and Fish Department and Bullhead City, a development plan was completed that calls for creation of a 53-acre backwater and restoration of 150 acres of riparian vegetation at the site.

Along Panoche Creek and Silver Creek, 6.5 miles of stream channel were acquired through exchange in California's San Joaquin bio-region.

One-half mile of rainbow trout habitat was improved, in cooperation with the South Dakota Game and Fish Department. BLM provided $\$ 15 ; 000$ and the state $\$ 15,000$ to create plunge pools, riffles and cover in a sections of stream that was channelized for a state highway. It is anticipated that the trout population will increase by over 300 percent in this popular fishery, less than one mile from the city limits of Sturgis, South Dakota.

Studies of Pelican Lake are getting underway in the Vernal District, to determine reasons for the decline of the once-trophy bluegill fishery. At one time, the lake was legendary for the bluegills it produced, some exceeding a pound-and-a-half.

Declining populations of Bonneville cutthroat trout are of major concern to BLM, as well as the public, in Utah's Richfield District. To better understand these populations, 35 miles of streams were monitored in 1994 for water quality parameters and macro-invertebrate populations.

Efforts to stabilize a one-fourth mile section of Otter Creek continued for a second year in the Richfield District. Boy Scouts and Future
Farmers of America helped with the project to plant over 1,000 willow. shoots and cottonwood poles that, combined with fencing and bank stabilization, are helping to heal deteriorated riparian and fisheries habitat." .

The Vernal District, in cooperation with the U.S. Forest Service and Utah Division of Wildlife Resources, is developing a management plan for the nationally known blue ribbon trout stream below Flaming Gorge Dam to the Colorado-Utah border. Fishing and recreation pressure is extreme, at times causing conflicts between anglers and boaters.

In Colorado, several important river properties were acquired by exchange or purchase in four BLM districts. All of the parcels have excellent riparian and fisheries values.

Rock placement projects improved fisheries on the middle Lake Fork of the Gunnison River in Colorado.

About 140 miles of riparian habitat was inventoried in Idaho's Burley District under contract with the Montana Riparian Association, and 500 willow cuttings were planted along Shoshone and Big Creeks. Cottonwoods are also being propagated for future planting.

Water quality monitoring was conducted on 15.6 miles of Clover Creek, in Idaho's Shoshone District.

Rock Creek, in the LaBarge Creek Watershed of Wyoming, is home to a small population of genetically pure Colorado River cutthroat trout. To protect trout habitat on portions of the creek, reconstruction of one riparian exclosure and maintenance of two others was completed. in Rock Springs District this summer. Volunteers from the Oak Brook (Chicago), Uinta and Pinedale chapters of Trout Unlimited helped complete the projects. 



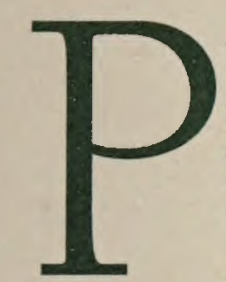
ublic land provides part or all of the habitat requirements for about 190 listed threatened and endangered plant and animal species, involving about 16 million acres of hábitat. Slowing the increase in listed species and recovering currently listed species are our major goals and a tremendous challenge for BLM.

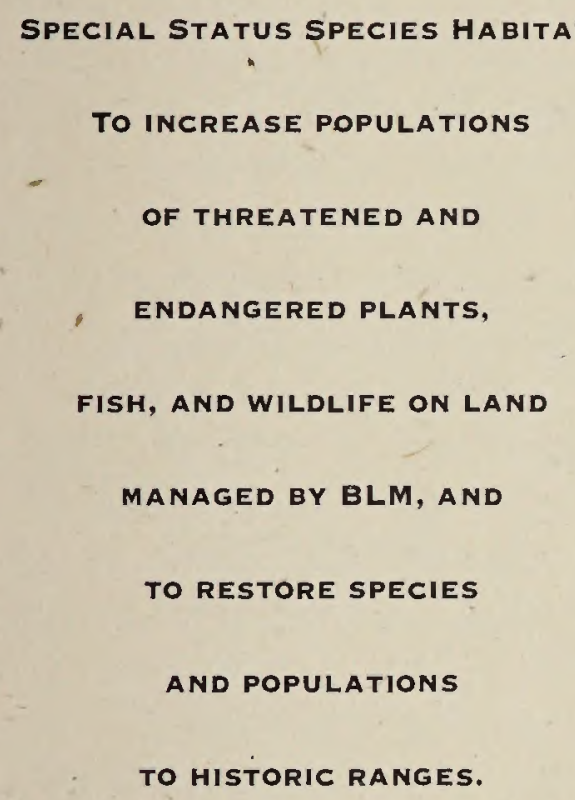

\section{SPECIAL STATUS PLANT HABITAT}

One in five native plants in the United States is at risk of extinction. More than 100 federally listed threatened or endangered plant species occur on BLM land, while another 700 species are candidates for listing. Tó preserve biological diversity, BLM must ensure continued survival of natural plant communities. BLM is striving to restore and maintain plant communities on public land so that they will be able to fill their roles in the ecosystem, such as filtering and retaining water to ensure a clean, reliable water supply; removing carbon dioxide from the atmosphere and restoring oxygen; retaining soil and increasing fertility; and providing habitat for wildlife and forage for livestock.

The Special Status Plants Program is relatively new to BLM, and much of our initial work involves inventory to determine the status and distribution of rare plants and natural plant communities. This basic information is essential for setting priorities for monitoring, research and conservation actions. For most special status plants, basic life history and ecological studies are needed to determine appropriate management actions.

\section{Selected Accomplishments:}

A rare plant community in Palm Beach County is being transferred to BLM from the Coast Guard, and will be managed to protect its 13 special status species.

An interagency effort is underway in Idaho to develop Conservation Agreements for candidate and sensitive plant species so that they don't need to be listed. Conservation Agreements are nearing completion for two plant species, while technical teams are begining work on 11 more. Idąho's only listed plant, MacFarlane's four-o-clock, is.being considered for downlisting from endangered to threatened, mostly due to BLM's conservation actions.

In Oregon, 29 new occurrences of special status plant species were documented. The most notable include a new finding of western lily (Lilium occidentale), the first known occurrence on BLM land. Other important discoveries on BLM lands were the presence of Wolf's eveningprimrose (Oenothera wolfii) and silvery phacelia (Phacelia argentea). An experimental population of a federal candidatel state listed plant,
Abronia umbellata, was established in Oregon.

In Oregon, 222 acres of habitat for two federal candidates, Calochortus greenei and Microseris laciniata ssp. detlingi were acquired. The area has one of the largest known populations of C. greenei in Oregon and was slated for subdivision into five-acre ranchettes, likely wiping out the population.

Two Challenge Cost Share agreements were implemented in Oregon to inventory rare lichen species and to develop a han'dbook to identify rare bryophyte species.

The Las Vegas District inventoried 18,000 acres for special status plants. The district also completed the California Bear Poppy Habitat Management Plan for 60,000 acres of public land in cooperation with the National Park Service and The Nature Conservancy.

The Marble Canyon Area of Critical Environmental Concern plan was completed, which will assist in recovery of the Brady pincushion

cactus in the Arizona Strip.

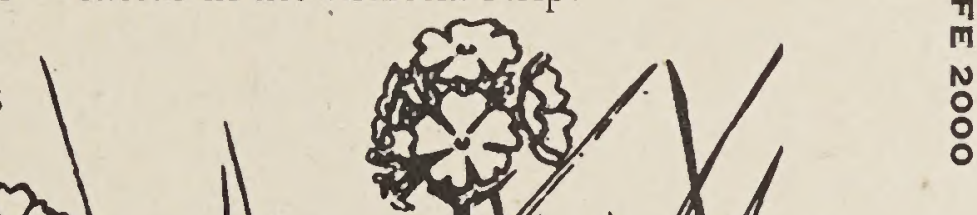


Through Challenge Cost Share, surveys were conducted on about 10,000 acres of the Phoenix Resource Area for Acuna Valley pineapple cactus. One new population was found and two others confirmed. Monitoring is being conducted for four other species: the Burro Creek cliffrose, white-margined penstemon, Cerbat beard-tongue, and the recently delisted Tumamoc globeberry, which is now a BLM sensitive-species.

Student Conservation Asso- ciation volunteers working for BLM inventoried 1,640 acres of public lands in a wind turbine field for the Coachella Valley milkvetch (Astragalus lentiginosus var. coachellae) in California. The species is proposed for federal listing as endangered.

A mitigation plan negotiated by BLM and U. S. Fish and Wildlife Service for a haul road to a sand and gravel mine included acquisition by BLM of surface management control of 10 acres of prime habitat for two endangered plants, the Santa Ana river woollystar (Eriastrum densiflorum spp. sanctorum) and slender-horned spineflower (Dodecahema leptoceras). The area will be managed as part of the new 760-acre Santa Ana River Wash Area of Critical Environmental Concern.

In California, inmate labor was used to improve palm oasis habitat and to provide access to the Desert Lily Preserve.

In the Arcata Resource Area, California, BLM is cooperating with The Nature Conservancy to eradicate alien plants in the Samoa and Manila, Dunes of Humboldt County, and restore habitat of Erysimum menziesii and Layia carnosa. In FY $1995, \$ 45,000$ is being committed to the effort.

A Challenge Cost Share, project was completed with the California Division of Forestry to fence a population of Fritillaria agrestris in the Hunter Mountain Area, that was being damaged by vehicles.

In Eldorado County, California 300 acres of gabbro substrate lands were inventoried for seven special status plant species. Coordination with California Department of Fish and Game and Eldorado County continues to create a preserve system spanning the gabbro formation.

California inventoried 4,500 acres in the San Joaquin Valley bioregion. Three new populations of threatened and endangered_species and three new occurrences of candidate species were documented. Eighteen populations of listed plants were monitored.

A BLM, The Nature Conservancy and California Department of Fish and Game study to improve habitat for the Owens Valley checker-bloom (Sidalcea covillei) through prescribed burning and removal of upland shrubs was completed within the two known populations on public land.

In California, ten populations of five rare plant species were intensively monitored for reproductive condition and habitat quality. The species are the Fish Slough milkvetch (Astragalus lentiginosus var. piscinensis), Alkali Mariposa lily (Calochortus excavatus), Mono astragalus (Astragalus monoensis), Mono Lake lupine (Lupinus duranii) and Mono Lake phacelia (Phacelia monoensis).

Over 348,000 acres were inventoried for 34 sensitive plant species in two districts and four resource areas in Montana. BLM provided $\$ 40,000$, which was matched by the Montana Natural Heritage Program, Montana State University and Alder Springs Consulting firm.

BLM and the Utah Natural Heritage Program located a site of Ute's ladies tresses near Callao, Utah, that was thought to have been extirpated. This site is on private land, and a search for other populations continues on adjacent BLM land.

Genetic studies funded by BLM in Utah provided the knowledge needed to revise the taxonomy of Maguire's daisy and reclassify two species as a single species. As a result, the U.S. Fish and Wildlife Service downlisted the species from endangered to threatened.

In the Salt Lake District, 13,000 acres were inventoried for the Category 2 plant Astragalus lentiginosus var. pohlii. The plant was found to occur more frequently than previously known, and federal listing is not recommended.

Utah's Cedar City District, in cooperation with several Challenge Cost Share partners, inventoried habitats of ten candidate species, expanding the known range of all and providing enough new status information to remove several from the need for federal listing.

BLM and the Utah Natural Heritage Program located a population of Cronquist woodyaster, a candidate species previously thought to be extinct. To protect the species, BLM initiated greenhouse germination and hybridization studies.

The University of Washington in St. Louis and BLM in Colorado combined financial support for genetic sampling of Eriogonum pelinophilum, a clay-loving wild buckwheat, to determine if this endangered species is a valid species.

Cooperative work with the University of Wyoming resulted in completing a floristic inventory of the San Miguel River watershed, Colorado. Inventories for clove phlox (Phlox caryophylla) and Mesa Verde cactus (Sclerocactus mesa-verdae) were completed. Inventories were also completed on 5,000 acres of habitat for the skiff milkvetch (Astragalus microcymbus), and 12 known sites were resurveyed in cooperation with the Colorado Natural Areas Program, and the Colorado Native Plant Society. Inventories were conducted on 5,000 acres of Gunnison milkvetch (Astragalus anisus) habitat, with numerous new occurrences reported.

Three sensitive plant species inventories totalling 7,600 acres were conducted in the Shoshone District, Idaho. Bugleg goldenweed and morning milkvetch were the target species. 
The Rawlins District and The Nature Conservancy, Wyoming, inventoried three special status species plants in the Lander Resource Area. The cedar rim thistle (Circium aridum), fremont bladderpod (Lesquerella fremontii) and desert yellowhead (Yermo xanthocephalus) all grow along the Continental Divide.

The Rock Springs District, Wyoming, began implementing management for the small rockcress (Arabis pusilla), a Category 1 candidate. Replacement and extension of four miles of protective exclosure fencing, off-road vehicle restrictions and mineral withdrawals were implemented in the Habitat Management Plan area.

Wyoming's Casper District and the University of Wyoming Rocky Mountain Herbarium funded the second year of a general floristic survey that covers about 700,000 acres. The first year of the survey produced the first and only locations of a federally threatened or endangered plant in Wyoming, Ute's lady tresses (Spiranthes diluvialis).

\section{SPECIAL STATUS FISH HABITAT AND BRING BACK THE NATIVES}

The Special Status Fishes Management Strategy Plan was completed in 1992. Work on many miles of stream and riparian habitat have improved fish production, especially in watersheds containing federally listed species and streams with fish at high risk of extinction.

Bring Back the Natives is a national campaign designed to improve the status of native aquatic species on public land through riparian area rehabilitation, watershed restoration, and species reintroduction. The program emphasizes application of ecosystem management principles to public land managed by BLM and U.S. Forest Service to conserve, restore, and maintain aquatic biological diversity. It was developed in 1992 by BLM, U.S. Forest Service and National Fish and Wildlife Foundation.
Selected Accomplishments:

Idaho's interagency effort to remove threats and develop Conservation Agreements on candidate and sensitive fish species is nearing completion for two fish species and is forming technical teams to work on ten others. Extensive consultation with the National Marine Fisheries Service is continuing for sockeye and chinook salmon.

The LaBarge Creek Watershed project in Wyoming's Pinedale Resource Area is a national showcase Bring Back the Natives project. BLM teamed up with the U.S. Forest Service, Wyoming Game and Fish Department, local and Chicago chapters of Trout Unlimited, local permittees and landowners to design projects for riparian and sensitive species fisheries habitat restoration.

The Coquille River Bring Back the Natives Partnership was formed by BLM, U.S. Forest Service, state agencies, private timber companies, local governmental agencies and environmental and sport interest groups in Oregon. With funding from the Governor's Watershed Health Program and the National Fish and Wildlife Foundation, several habitat projects were begun, including making a major culvert barrier on private timber land passable for anadromous fish. The project will reopen 15 miles of historic salmon habitat in the Baker Creek watershed. The actions will also benefit coho salmon and steelhead trout, both petitioned species in the basin.

Oregon completed surveys of

Warner Sucker (Catostomus warnerensis) habitat that documented a range extension into new habitats, completed surveys of 30 miles of redband trout habitat, and monitored 75 miles of native fish-bearing streams for riparian maintenance and recovery.

In the Tucson Resource Area, aquatic habitat surveys were completed on four streams in the Muleshoe area. The surveys quantified habitat conditions for five native fish species, all federal candidates.
The Tucson Resource Area assisted the Arizona Game and Fish Department with surveys for the federally endangered Gila Topminnow (Poeciliopsis occidentalis), and worked on a cooperative reintroduction protocol for the species with the Department and the U.S. Fish and Wildlife Service.

The headcut repair on Cienega Creek was completed during fourth annual Tucson Resource Area Earth Day activities. Over 50 fifth and sixth grade students placed stream stabilization structures and planted trees and grasses to help protect habitat for the endangered Gila topminnow.

The Mary's River Bring Back the Natives Challenge Cost Share project in Nevada includes realigning the Cabin Field powerline, inventorying Lahontan cutthroat trout populations and classification of riparian vegetation to identify project work to improve wildlife habitats and public enjoyment of this area. Cooperators include Nevada Division of Wildlife, National Fish and Wildlife Foundation, and Trout Unlimited and Wells Rural Electric Co.

In cooperation with the Arizona Game and Fish Department, Gila chubs (Gila intermedia) were reintroduced into three sites on public lands in the Phoenix Resource Area, and special status fish species populations were monitored along eight streams.

Wyoming's Rawlins District completed the Colorado River cutthroat trout - Little Snake River Enclave Plan for the conservation and reintroduction of Colorado River cutthroat trout (Oncorhynchus clarki pleuriticus), a Category 2 species.

Fish sampling in Aravaipa Creek with The Nature Conservancy was completed in Arizona. Species included the threatened spike dace (Meda fulgida) and loach minnow (Rhinichthys cobitis), as well as the candidate Sonoran sucker (Catastomus insignis), desert súcker (C. clarki) and Gila chub. 
The Shivwits Resource Area inventoried 35 miles of riverine habitat for presence of federally endangered woundfin minnow (Plagopterus argentissimus) and Virgin River chub and candidates Virgin River spinedace (Lepidomeda mollispinis), flannelmouth sucker (Catastomus latipinnis) and desert suckers. Studies of growth and the timing of spawning were also carried out.

In Arizona, five coves at Lake Havasu were renovated to serve as predator-free rearing areas for special status fish. Over 36,000 juvenile razorback suckers and 44,000 juvenile bonytail chub are being reared in these coves, and eventually will be stocked intothe lake.

Tamarisk eradication continued at the Afton Canyon Area of Critical Environmental Concern in California's Barstow Resource Area. BLM staff, volunteers, and an inmate crew removed 30 acres of tamarisk this year. Fifty acres previously treated were retreated to combat resprouting.

The American Forests Association (Global Re-leaf) assisted BLM's Barstow Resource Area in locating a corporate sponsor for the Afton Canyon Saltcedar Removal Project. The sponsor, Absolut Vodka, pledged $\$ 5,000$ to purchase tree planting equipment. Volunteers also initiated a long-term monitoring program to document the response of amphibians and reptiles to the Afton Canyon rehabilitation effort.

BLM, Trout Unlimited, Montana State University and the Montana Department of Fish, Wildlife and Parks evaluated two Westslope cutthroat trout areas on BLM lands. Migration barriers, to prevent contamination from. rainbow trout and Westslope population augmentation, were installed on one BLM site.

A cooperative bull trout radio telemetry study was undertaken by BLM, The American Fisheries Society, U.S. Forest Service, Montana Department of Fish Wildlife and Parks, and Trout Unlimited, to determine habitat requirements and ways to improve habitat. BLM provided $\$ 5,500$ toward the study, with partners contributing $\$ 61,000$. The project covered 282 miles of the Blackfoot and Clark's Fork rivers.

A joint project in the Billings Resource Area with the U.S. Forest Service and the Montana Department of Fish, Wildlife and Parks, removed brown trout from four miles of Yellowstone cutthroat trout habitat on Bad Canyon Creek. The habitat was secured by constructing a barrier in the stream to stop upstream migration of brown and rainbow trout. The project ensures healthy populations of mixed species below the barrier and a pure strain cutthroat trout population on BLM and Forest Service lands above the barrier, all accessible to the public.

In Utah, an inventory for population distribution and abundance of flannelmouth sucker and leatherside chub (Gila copei) continued into 1994. About 20 miles of streams were inventoried this year, and five miles re-inventoried. Flannelmouth sucker and leatherside chub were found farther downstream in the system than earlier recorded.

In the Book Cliffs Initiative Area, through matching funds from the Bring Back the Natives program and the Utah Division of Wildlife Resources, three gap fences along Bitter Creek were constructed to control livestock use along the riparian bottoms to protect the year-long flows.

Macroinvertebrate population baseline studies were established in Utah on ten stream miles for the Colorado River cutthroat trout, to evaluate responses to changes in livestock grazing management. Five miles of stream were assessed to determine suitability for reintroduction. Fence maintenance was provided by the local chapter of Trout Unlimited on two miles of stream.

\section{SPECIAL STATUS \\ ANIMAL HABITAT}

Not many years ago, the list of threatened, endangered and special status wildlife was limited to a handful of well-known species - bald eagles, peregrine falcons, black-footed ferrets and a few others. Now, the list is much longer and BLM's responsibilities for special species management are growing.

\section{Selected Accomplishments:}

Five years of a demographic study on the northern spotted owl on 220,000 acres of land was completed in Oregon, and 330 owl sites were monitored.

Oregon's Coos Bay District has three biologists and a botanist on the Snowy Plover Working Group, which is working to restore habitat for the threatened plover. Snowy plover habitat has been lost along the Oregon Coast primarily due to introduction of European beachgrass, an aggressive exotic that has changed the nature of the beaches and dunes along the coast. The Coos Bay District scarified and burned the beachgrass on 40 acres of coastal dunes. At least four

pairs of plovers nesting on the rehabilitation site

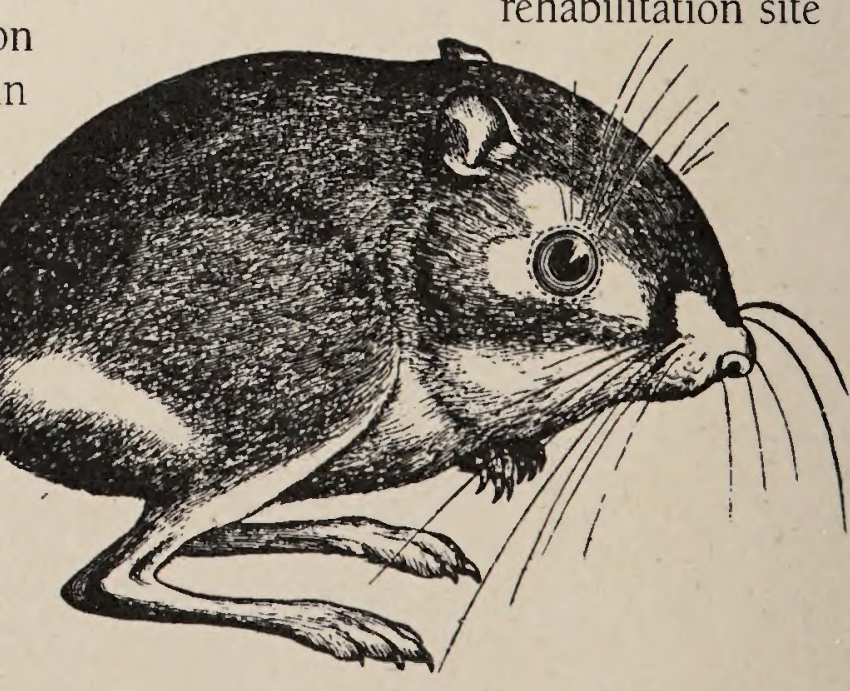


were later documented. Cooperators include The Nature Conservancy, Oregon Department of Fish and Wildlife, U.S. Army Corps of Engineers, U.S. Forest Service, Dunes National Recreation Area, Cape Arago Audubon Society and the U.S. Fish and Wildlife Service.

Several years' effort culminated in the acquisition of 6,600 acres of key Columbian white-tailed deer habitat in Oregon. The area also offers an opportunity to manage interior valley oak woodland habitat, which has been almost exclusively in private ownership. Two additional exchanges are currently being pursued. When completed, they would meet the recovery criteria of 500 animals. Downlisting of this high-profile species could be accomplished as a result of BLM actions.

As part of the Florida Resource Management Plan, stipulations were developed to reduce impacts to special status species from development of limestone, phosphate and oil and gas resources. Species include the gulf sturgeon, bald eagle, red-cockaded woodpecker, Florida panther and Choctawhatchee beach mouse. Challenge Cost Share funds were used to continue intensive population monitoring of the Florida scrub jay on a tract in Jupiter, Florida.

Idaho's interagency effort to remove threats and develop Conservation Agreements on candidate and sensitive animal species in nearing completion for one mammal (Idaho ground squirrel), one bird (harlequin duck), one salamander (Coeur d'Alene salamander), and one invertebrate (dunes tiger beetle). Technical teams are being formed to begin Conservation Agreements on an additional five mammals, six birds and one amphibian.

The Shoshone-Eureka Resource Area of the Battle Mountain District conducted snowy plover inventory on 45,000 acres of habitat in cooperation with the Nevada Division of Wildlife.

Tonopah Resource Area of the Battle Mountain District in Nevada constructed a five-acre exclosure around a spring that provides some of the only habitat occupied by the Armagosa toad.

Four releases of captive-reared endangered peregrine falcons were completed on BLM land in Montana. Two releases were in cooperation with The Peregrine Fund and the Montana Department of Fish, Wildlife and Parks. Two releases were assisted by Ralph Rodgers, a nationally known falconer who lives in Montana. Twenty-eight birds were released, and 26 fledged. A two-year old bird returned to the Missouri River from a previous release. In 1980 there were no known wild nesting peregrine falcons in Montana. This year, there were 16-18 wild pairs known to have nested, all a result of the release program in which BLM has beèn a major participant.

A private consulting firm, Fauna West, provided $\$ 8,000$, (BLM $\$ 5,000$ ), for a statewide mountain plover habitat identification and description in Montana. A final publication of the species habitat requirements will be published in FY 1995.

Over 300 miles of the Yellowstone River were inventoried for nesting peregrine falcons, and reintroduction sites were identified. BLM provided $\$ 5,000$ for the work, with the Craighead Institute and The Peregrine Fund contributing $\$ 10,000$.

More than 180 miles of habitat on the Yellowstone, Clark's Fork of the Yellowstone, the Powder River, and 175 miles on the Clarks Fork and adjacent streams in the Columbia River drainage were monitored for bald eagle nesting success in Montana. In addition, 18 bald eagle nests were monitored for nesting success and the 175 miles examined for new nesting.

Baseline data was gathered in the Dillon Resource Area on 125,000 àcres of pygmy rabbit habitat in coop-eration with the Montana Department of Fish Wildlife and Parks. The project determined that the most suitable habitat is currently unoccupied, Yellow-billed cuckoo surveys were conducted on the San Pedro
National Conservation Area in Arizona in anticipation of that species upcoming petitioning for listing.

BLM obtained an Arizona Game and Fish Department Heritage Fund Grant to determine distribution of the rare House Rock Valley chisel-toothed kangaroo rat. Inventory for three other species is ongoing in the Kingman Resource Area, including Hualapai Mexican vole habitat, bat roosts, and lowland leopard frog habitat.

In cooperation with Arizona Game and Fish Department, Marine Corps Air Station, and U.S. Fish and Wildlife Service, a research project on the proposed threatened flat-tailed horned lizard was started in the Yuma District. Thirty study plots were established to measure horned lizard densities in different habitats. The information will be used in conjunction with LANDSAT imagery to determine if critical habitat can be predicted with remote sensing.

BLM's Arizona Strip is working closely with the U.S. Fish and Wildlife Service and the California Condor Recovery Team, evaluating the potential for releasing captivereared condors into the Grand Canyon ecosystem.

In California, over 15,000 acres of Northern Spotted Owl habitat was inventoried and 16 known territories monitored.

Two prescribed fires were completed in California's Carrizo Plain Natural Area to assist in the U.S. Fish and Wildlife Service mountain plover monitoring study. A small mammal trapping grid was established on one of the burns to monitor effects of fire on the federally endangered giant kangaroo rat.

A second year of inventory work for mountain plovers on the Myton Bench in Utah, was completed on 20,000 acres, with 20-25 adults and nine young in six broods found.

In cooperation with Utah Division of Wildlife Resources, nine areas of the Vernal District were surveyed for ferruginous hawk nests. Ten nests with 19 young birds were located, 
including three new sites. In the Salt Lake District, about 40,000 acres were inventoried for ferruginous hawks. Six new active nests were located.

Mexican spotted owl inventories continued in Utah, and a nesting pair with three juveniles was found in the Richfield District. An additional male was also verified, bringing the total to two adult pairs, five juveniles and five other owls either heard or confirmed. In the Cedar City District, Mexican spotted owls were located in three new locations.

In Utah's Cedar City District, an inventory of the spotted bat, a candidate species, began under a Challenge Cost Share agreement. Bats were located at two of five sites during the first survey.

About 100,000 acres in Utah were surveyed for Utah prairie dogs in a combined effort with the U.S. Forest Service and Utah Division of Wildlife Resources. This year's count on BLM land totaled 86 prairie dogs, more than double last year's number. The counts are still far below the 900 recorded in the late 1980s.

Surveys of spotted frog habitat in Utah's West Desert revealed the population to be stable.

In the Salt Lake District an ongoing study of 3,000 acres of snowy plover nesting habitat was inventoried around the Great Salt Lake wetlands complex.

In the Washakie Resource Area in Wyoming, six peregrine falcons were released, in cooperation with The Peregrine Fund.

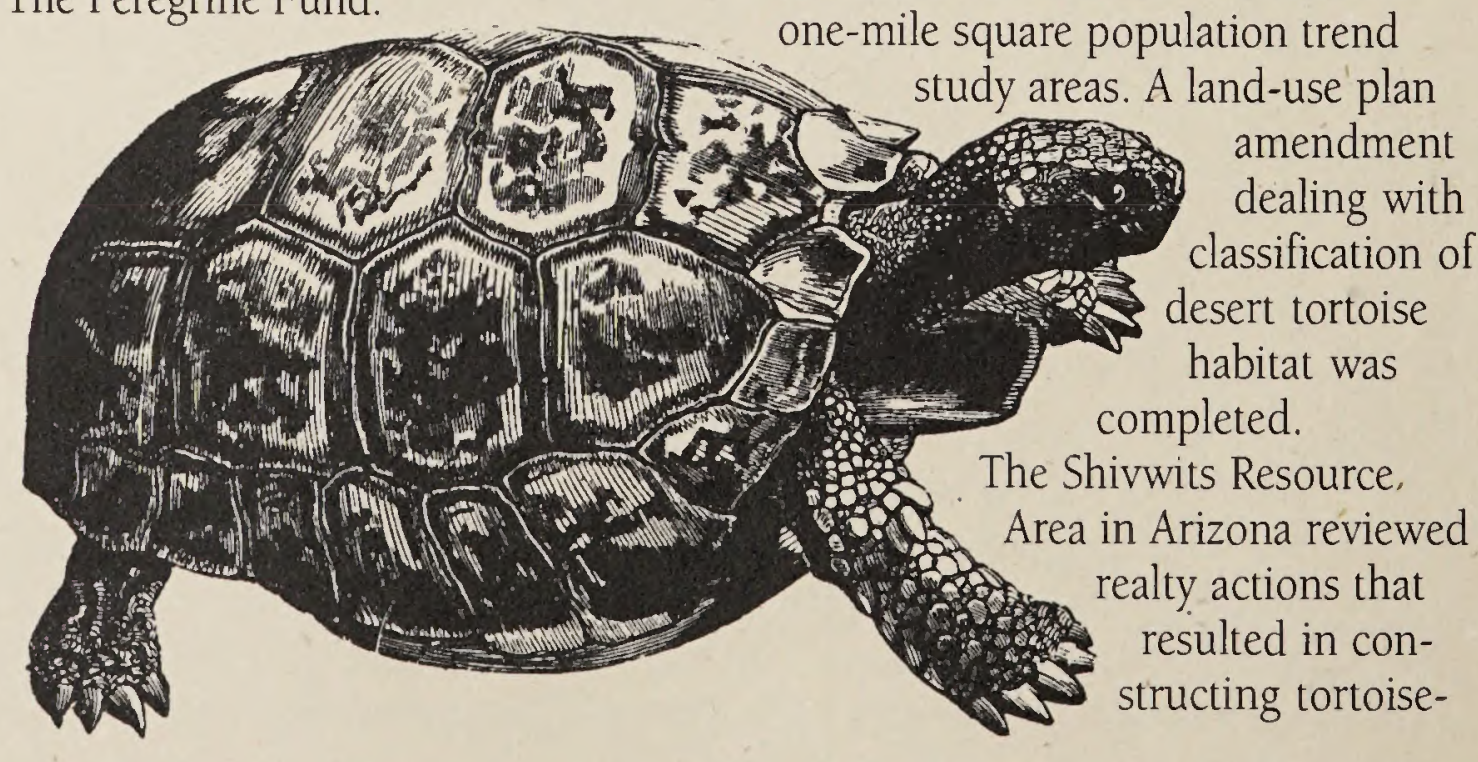

In the Lander Resource Area, a similar hack (release) site was operated at Suicide Point in the Wind River Mountains. For the second year fledgling peregrines were released at a BLM hack site in the Upper Green River Habitat Management Plan area. It is a Challenge Cost Share project with The Peregrine Fund, the Wyoming Game and Fish Department, and the Keller family (adjacent landowners).

The Rawlins District is actively involved in a multi-year project to improve nesting habitat and nesting success for ferruginous hawks. Seventy-one artificial nesting structures have been erected at sites where hawks are impacted by developments, primarily powerlines and oil and gas condensation tanks. The structures have increased nesting success and production. In a cooperative effort with the University of Wyoming, 135 young ferruginous hawks were banded this year.

As part of Wyoming's Upper Green River Habitat Management Plan, five trumpeter swan cygnets were released into the New Fork Potholes area, to expand the range of this candidate species. A well was drilled to provide a continuous supply of water to the potholes. Waterfowl islands will be constructed and willow plantings made in FY 1995.

\section{DESERT TORTOISE}

In Arizona, desert tortoise numbers were monitored on three one-mile square population trend study areas. A land-use plan amendment classification of desert tortoise ompleted.

Shivwits Resource, realty actions that resulted in constructing tortoise- proof protective fencing around a 12 acre state transportation maintenance yard and a one-acre material source pit. The California State Director chaired the Management Oversight Group for the desert tortoise. The group is.comprised of federal and state agency heads from all four states with desert tortoise habitat. On June 28, 1994, the state director signed the Desert Tortoise (Mojave Population) Recovery Plan, marking the first time BLM and agencies other than the U.S. Fish and Wildlife Service took part in approval of a recovery plan.

Off-road vehicle designations and road closures were completed for Eldorado Valley on 202,000 acres of desert tortoise habitat, in cooperation with The Nature Conservancy and Clark County, Nevada.

BLACK-FOOTED FERRET

A full time black-footed ferret biologist was hired in the Phillips Resource Area in Montana.

Black-footed ferret introduction is scheduled for early FY 1995 in Montana, on the Charles M. Russell National Wildlife Refuge. The ferrets are expected to immediately occupy adjacent prairie dog colonies on BLM land. Information will be gathered on habitat selection and the survival and breeding success of individual ferrets. - The latter may be one of the most important factors in the effort to recover the almost-extinct mammal. The gene pool for the captive population has less than ten donors.

The Vernal District in Utah continued work to complete a ferret reintroduction and management plan for the Coyote Basin area of the Book Cliffs Resource Area.

Monitoring of prairie dog ecosystems is continuing in preparation for possible reintroduction of the black-footed ferret in Colorado. BLM and Colorado Division of Wildlife completed surveys and monitoring of prairie dog densities on two potential reintroduction sites totalling more 
than 130,000 acres. The goal is to have both sites ready for ferrets by 1995 or 1996.

Wyoming BLM is continuing its cooperation with the U.S. Fish and Wildlife Service and Wyoming Game and Fish Department to maintain a wild population of black-footed ferrets. There have been several habitat evaluations prior to reintroductions and monitoring efforts to determine success of releases, with wild born ferret litters in the past three years in Rawlins District's Shirley Basin. Almost 300 adult black-footed ferrets have been released on BLM public land over the last four years.

Wyoming's Rock Springs District inventoried or monitored 12,000 acres of praire dog colony habitat to identify potential habitat for black-footed ferrets. Much of the work was in conjunction with oil and gas clearances. The Platte River Resource Area assisted in nighttime spotlight surveys for black-footed ferrets. In the Buffalo Resource Area, work contines to search for or verify the presence of black-footed ferrets.

FIGURE 3

THREATENED, ENDANGERED \& CANDIDATE SPECIES BY STATE

BLM FY94

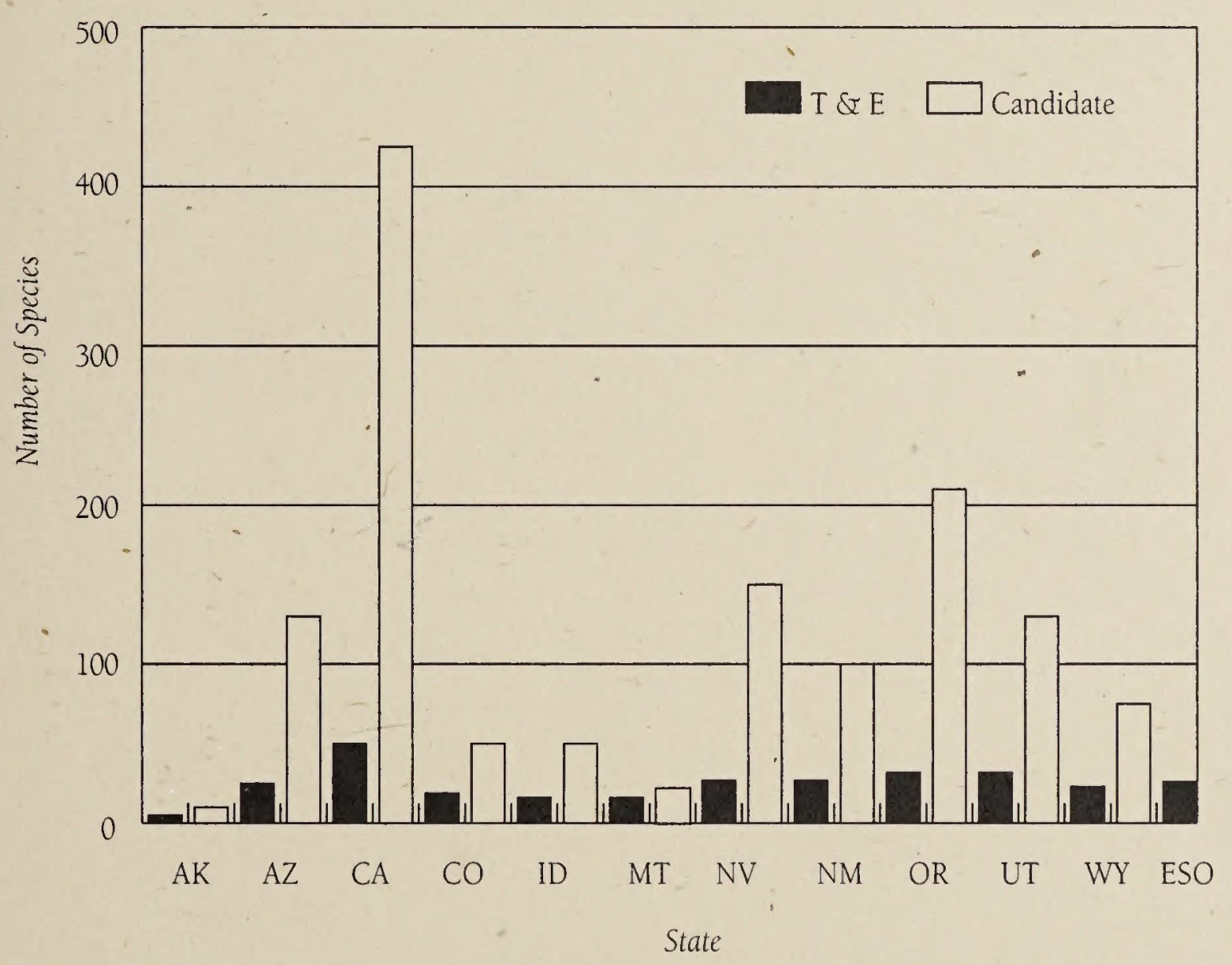





\section{BUDGET}

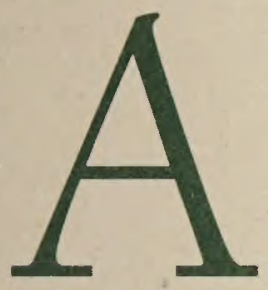

$s$ a result of widespread acceptance of Fish and Wildlife 2000 and its accomplishments on the ground, budget levels for BLM's wildlife program have increased over the last several years. Nonetheless, at the present funding levels, the management work needed will require two or more decades to complete. During that time, many listed species likely will further decline, while additional species will be classified as threatened or endangered. Once a species is placed on the list, the cost of recovery is exorbitant. Protecting and managing these species before they are listed is much more effective and in the national interest. To achieve this, BLM must be adequately funded and staffed to implement the strategy plans ensuring compliance and protection of listed species.

The graphs below delineate the budget situation for the Division of Wildlife and Fisheries through Fiscal Year 94. Cost estimates have been prepared for completion of the various state and national strategy plans. (Figures 4,5,6)

\section{STAFFING}

Though staffing has increased in the last several years, the increases have consistently lagged behind budget. In part, the situation is due to hesitancy to add wildlife positions during a time of general downsizing in government. (Figure 7)

FIGURE 4

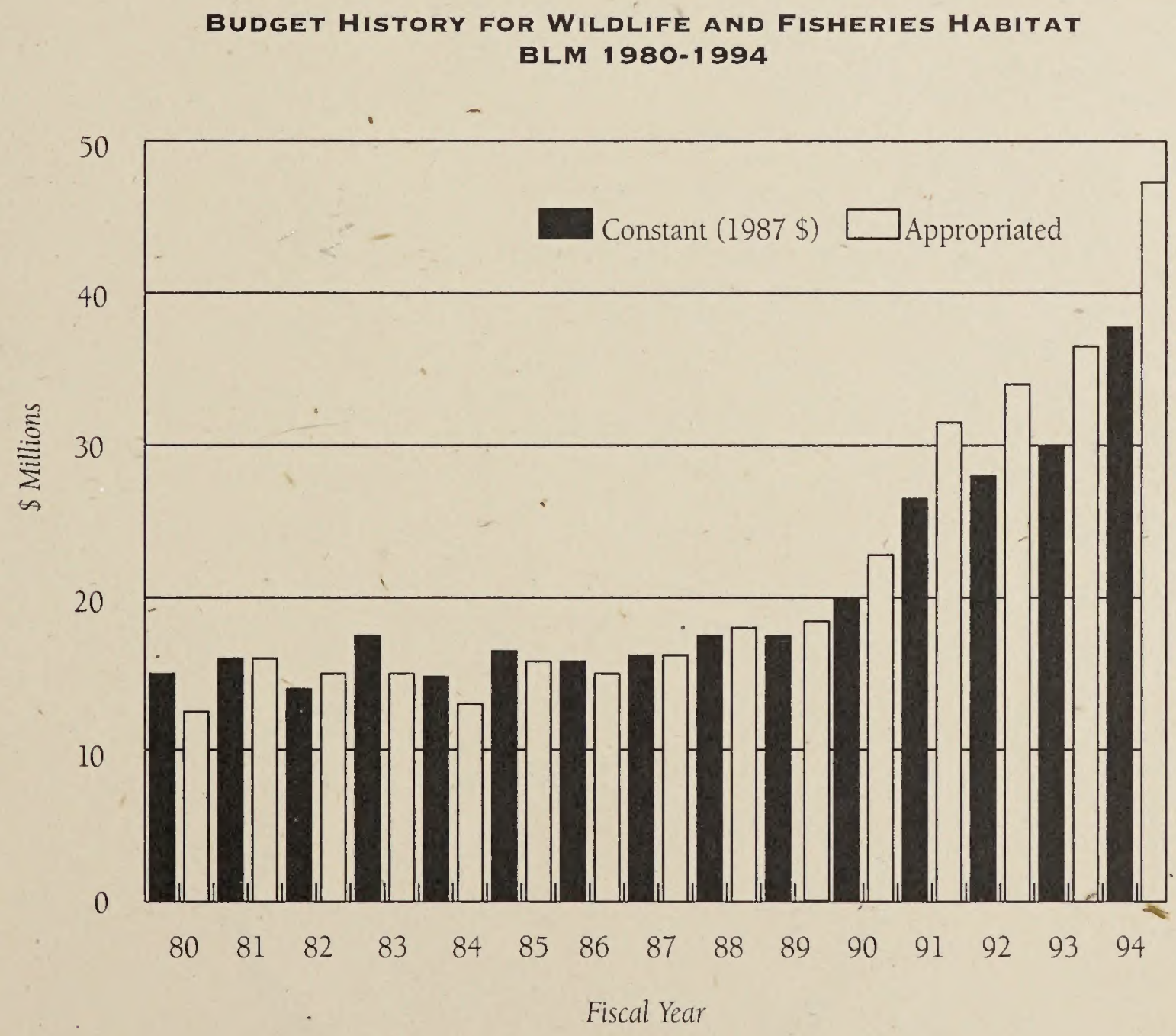




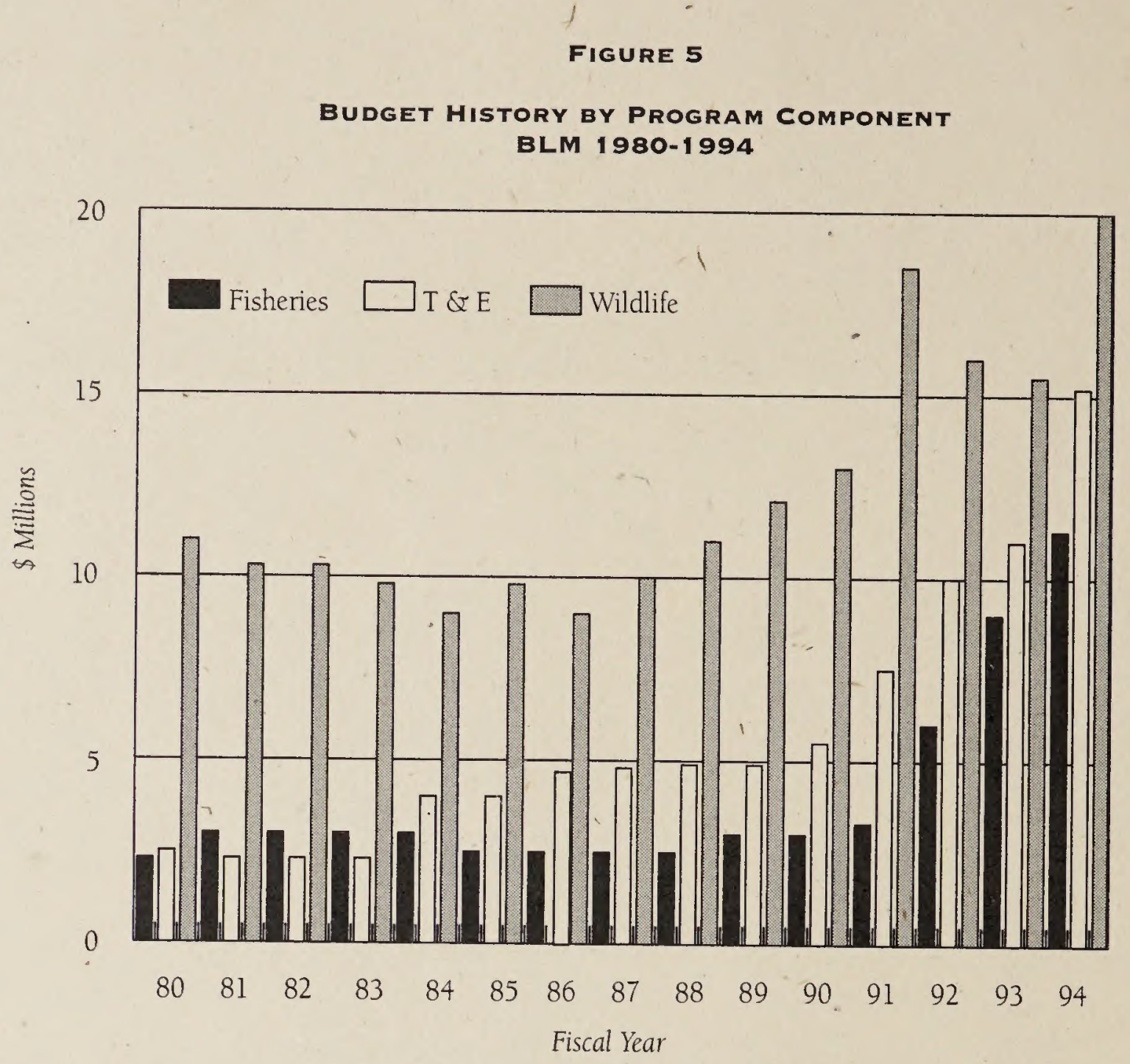

FIGURE 6

EXPENDITURES BY PROGRAM ELEMENT BLM FISCAL YEAR 1994

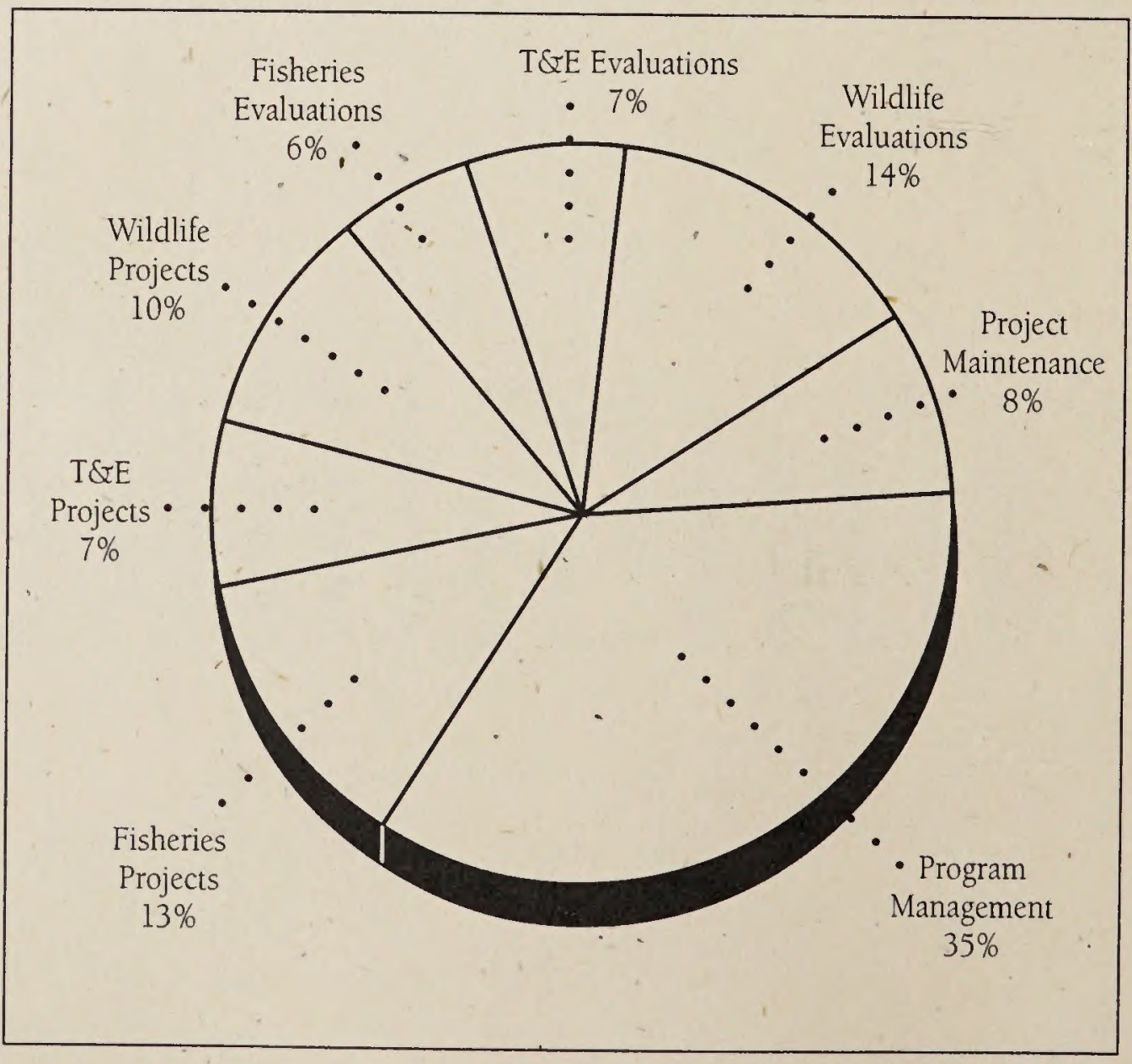




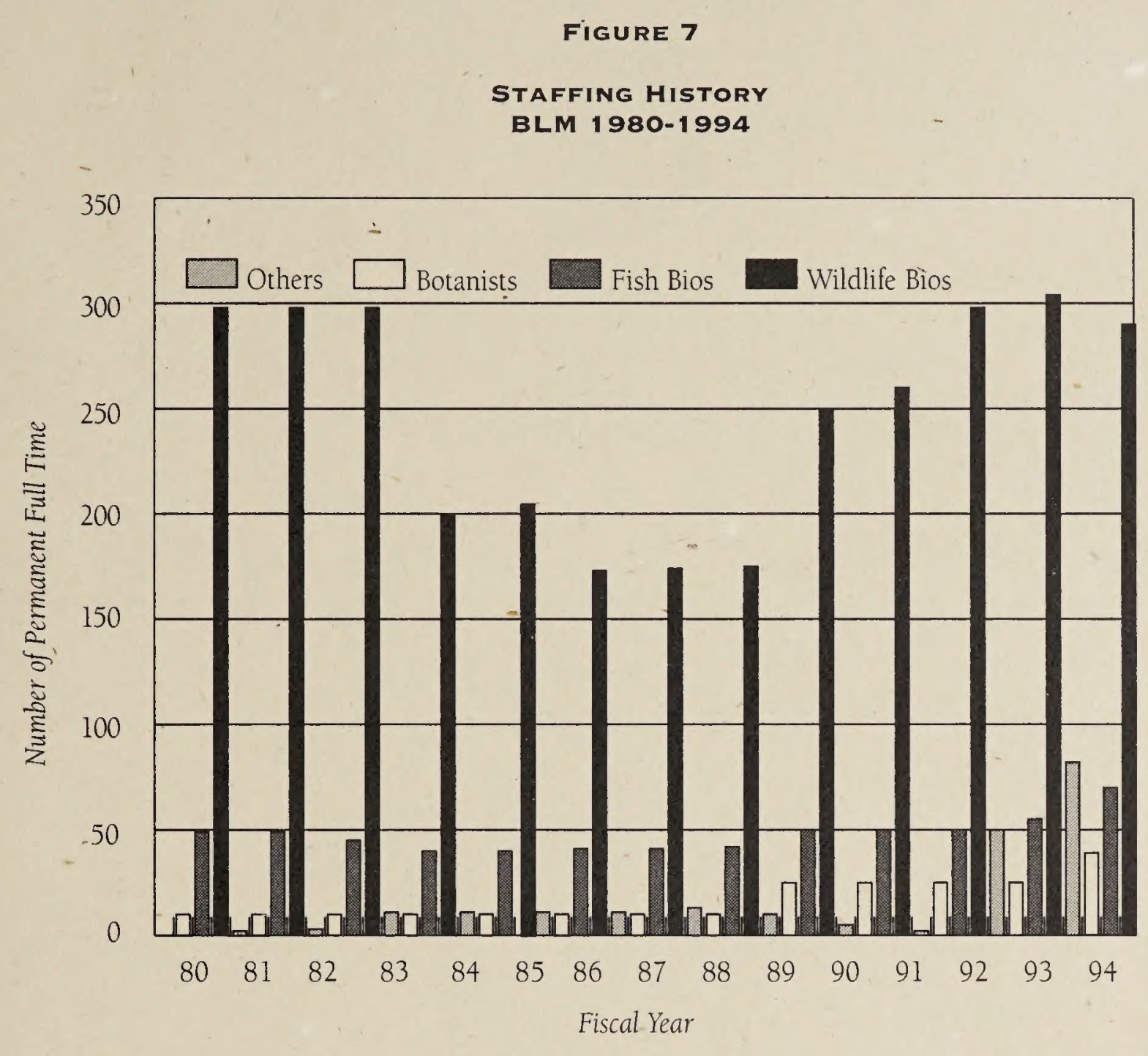



Agencies and organizations with which BLM has partnership agreements and/or operations for conservation on public land.

45 North, Inc.

Abandoned Mine-Finders

Absolut Vodka

Agency for International Development

Agricultural Soil Conservation Service

Alaska Department of Fish and Game.

Albertsons College (Idaho)

Alderspring Ecology

American Birding Association

American Forest Resource Alliance

American Forest Council

American Forests (Global RELEAF)

American Fisheries Society

American Ornithologists' Union

Amerifish Corporation

AMOCO Production Company

Anglers United

Animal and Plant Health Inspection Service.

Animal Damage Control

Aqua Bonita Flycasters

Arizona Game and Fish Department

Arizona Boys Ranch

Army Corps of Engineers

ASARCO Inc.

Atchison, Topeka, and Santa Fe Railway Co. AZCO Mine

Barrick Goldstrike Mines, Inc.

Bass Anglers Sportsman Society

Bat Conservation International

Berkeley Inc.

Berry Botanic Garden

Big Hole River Foundation

Bighorns Unlimited

Bighorns Unlimited of Elko

Boise State University

Bowhunters of Wyoming

Boy Scouts of America

Brigham Young University

Bring Back the Natives

Brown-Berry Biological Consultants

Bureau of Reclamation

Bureau of Indian Affairs

California Energy Commission

California Water Quality Control Board

California Trout

California Department of Fish and Game

Cape Arago Audubon Society

Casper Recreation Department

Celsius Production Company

Center for Plant Conservation

Central Utah Project

Cheney High School

Citizens Against Poisoning the Environment

Clean Lakes

Colorado Division of Wildlife

Colorado Land Board

Conservation International

Coors Pure Water 2000 Program

Coos Lake Resource Conservation District
Cornell Laboratory Manomet Bird Observatory

of Ornithology Maricopa County Parks Department

Council Mothers $\because 3$ Mattole River Restoration

For Clean Water : $\quad$ Medicine Butte

Craighead Institute

Creswell Middle School

Creswell Urban

Forestry

Association

Crook

County

School

District

Defenders of

Wildlife

Department of Defense

Department of the Army

Department of the Air Force

Department of the Navy

Deschutes Llama Foundation

Ducks Unlimited

Dunes National Recreation Area

EGEG Energy Measurements

E.J. White Construction Company

Eastern Washington University

Elko Bighorn Sheep Unlimited

Environmental Protection Agency

Fauna West

Federation of Fly Fishermen

Fish and Wildlife Service

Fish American Foundation.

Forbes Seed Company

Fort Sage School District

Foundation For North American Wild Sheep

Fresno Sportsmen Association

Future Farmers of America

Girl Scouts of America

Golden Eagle Audubon Society

Great Basin National Park

Gunnison Angling Society

Gunnison Gorge Anglers

Hawk Mountain Sanctuary

Hawkwatch International

Idaho Bird Hunters

Idaho Riparian Cooperative

Idaho Conservation Data Center

Idaho Soil Conservation Commission

Idaho State University

Idaho Department of Fish and Game

Idaho Department of Parks and Recreation

Inland Northwest Wildlife Council

International Association of Fish and

Wildlife Agencies

International Paper Co.

Izaak Walton League of America

Joe Rupp Trust Fund

Kern River Flyfishermen

Kittitas Field and Stream Club

L.U. Ranch

Lahontan Chapter, Audubon Society

Las Vegas Flycasters

Lassen City School District

Lone Rock Paper Co.
Wildlife

Association

$\rightarrow$

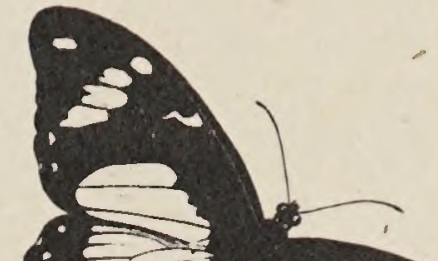

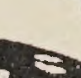
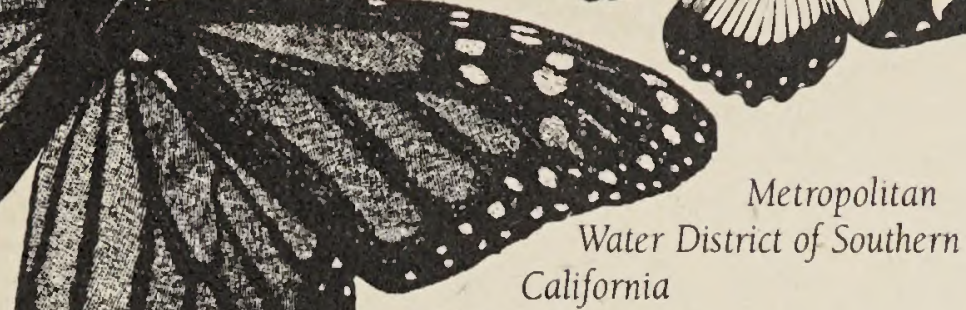

California

Mobile Oil Company

Modoc/Alturas Chapter

Montana Department of Fish, Wildlife, and Parks

Montana Riparian Association

Montana State University

Mule Deer Foundation

National Rifle Association

National Wild Turkey Federation

National Wildlife Federation

National Fish and Wildlife Foundation

Native Plant Society, Spokane Chapter

Native Plant Society of Oregon

Nevada Chukar Foundation

Nevada Division of Forestry

Nevada Department of Wildlife

New Mexico Department of Game and Fish

North American Outdoor Group

North Carolina Heritage Program

North Okanogan Sportsmen's Council

North Carolina Wildlife Resources Commission

North Idaho Flycasters

North Carolina Plant Conservation Program

Northeast Nevada Chapter

North Platte Chapter, Walleyes Unlimited

Northern Rockies Conservation Cooperative

Odessa Economic Development Council

One Shot Antelope Foundation

One Shot Antelope Society

Oregon Department of Fish and Wildlife

Oregon State University

Oregon Governor's Watershed

Enhancement Board

Pacific Coast Joint Venture

Pacific Power and Light

Pheasants Forever

Phillips Petroleum

Placer U.S.

Quail Unlimited

Questar Pipeline Company

Ritzville High School

Rocky Mountain Elk Foundation

Rocky Mountain Herbarium,

University of Wyoming

Roseburg Resources

Ruffed Grouse Society

Sacramento Urban Creeks Council 
Safari Club International

San Juan Chapter, National Audubon Society

Seneca Paper Co.

Shimano American Corporation

Southern Oregon State College

Spokane Audubon Society

Spokane Gun Dog Club

Sprague High School

Sweetwater Wildlife Association

Tennessee Valley Authority

The California Council

The Cottage Grove Urban Forestry Association

The Wilderness Society

The Peregrine Fund

The Wyoming Council

The Georgia Council

The In-Fisherman

The Izaak Walton League of America

The Wildlife Society

The Nature Conservancy

Times/Mirror Magazines Conservation Council

Trout Unlimited

Umpqua Fishermen and Steamboaters

Union Pacific Resources

University of California at Berkeley

University of California Cooperative Extension

University of Nevada, Reno

University of Idaho
University of California, Riverside

University of Montana

University of Colorado

USDA Extension Service.

UDSA Forest Service

USDA Soil Conservation Service

USDI Sequoia-Kings Canyon National Park

USDI Bureau of Indian Affairs

USDI Bureau of Reclamation

USDI Fish and Wildlife Service

USDI National Park Service

Utah Division of Parks and Recreation

Utah Division of Wildlife Resources

Utah State University,

College of Natural Resources

Washington State University

Washington Ornithological Society

Washington Natural Heritage

Washington Department of Fish and Wildlife

Waters for Wildlife

Wells Rural Electric Co.

Wenatchee Valley College

Western Area Power Administration

Western Ecological Studies Team

Western States Mineral Corporation

Wexpro Exploration Company

Weyerhaeuser Paper Co.

Wildlife Conservation Board of California
Wildlife Forever

Wildlife Management Institute

Wildlife Conservation International

Williams Field Service

Wolf Haven

World Wildlife Fund

Wyoming Department of Environmental Quality

Wyoming Flycasters

Wyoming Game and Fish Department

Yakima Indian Nation

Partnership coalitions:

Central Valley Habitat Joint Venture

Federal Neotropical Migratory

Bird Conservation Committee

Intermountain West Joint Venture

National Environmental Education Council

Pacific Coast Habitat Joint Venture

Partners In Flight

Prairie Pothole Habitat Joint Venture

U.S. Forest Service/BLM PACFISH

Strategy Team

Western Governors Association, Great Plains Initiative 
Courses completed by the National Training Center with the assistance of Habitat Management (4350) funding.

Ecosystem Management Module E Video Design

Course \#1730-01

Interdisciplinary Resource Management 6 sessions

Course \#1730-03

Meeting the Biodiversity Challenge 5 sessions

\section{Course \#1730-04}

Applied Biodiversity Conservation

4 sessions

Course \#1730-05

Inventory and Monitoring of Special Status Plants

l session

\section{Course \#1730-07}

GIS in Resource Management

6 sessions

Course \#1730-11

Geodata Collection and Use

1 session

\section{Course \#1730-15}

Communications and Leadership 3 sessions

Course \#1730-16

Policy and Socioeconomics

2 sessions

Course \#1730-18

Mines and Bats

1 session

\section{Course \#1737-01}

Riparian Management

2 sessions

Course \#6000-12

Threatened and Endangered Species

Conservation and Management

2 sessions

\section{Course \#6000-35}

Conservation of Neotropical Migratory Birds 1. session

Course \#8300-5

Watchable Wildlife: Spotlight on Diversity

1 session

\section{Course \#8500-1}

Multiple Use in Wilderness (design and pilot)

l session

Course \#9180-5

Advanced GIS

2 sessions 
of

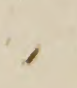


THE ILLUSTRATIONS THAT APPEAR THROUGHOUT THE

FISH \& WILDLIFE 2000 ANNUAL REPORT ARE

NINETEENTH-CENTURY WOOD ENGRAVINGS.

THIS ELEGANT FORM OF ILLUSTRATION WAS USED

FOR INSTRUCTION, AS WELL AS ARTISTIC PURPOSES.

THE SOURCE OF THESE ILLUSTRATIONS IS ANIMALS:

A PICTORIAL ARCHIVE FROM NINETEENTH-CENTURY

SOURCES (1419 COPYRIGHT-FREE ILLUSTRATIONS

OF MAMMALS, BIRDS, FISH, INSECTS), SELECTED

by Jim HaRter, Dover Publications, New York.

THE ART IS REPRODUCED FROM BREHM'S TIERLEBEN

(ANIMAL LIFE); THE PICTORIAL MUSEUM OF ANIMAL

NATURE (CHARLES D. KNIGHT, LONDON); THE RIVERSIDE

NATURAL HISTORY (HOUGHTON MIFFLIN, BOSTON);

JOHNSON'S NATURAL HISTORY (ALVIN J. JOHNSON

\& SON, NY); AND the FRENCH PERIOdical La Nature.

THE BOTANICAL ILLUSTRATION ON PAGE 27

IS BY METTE HANSON.

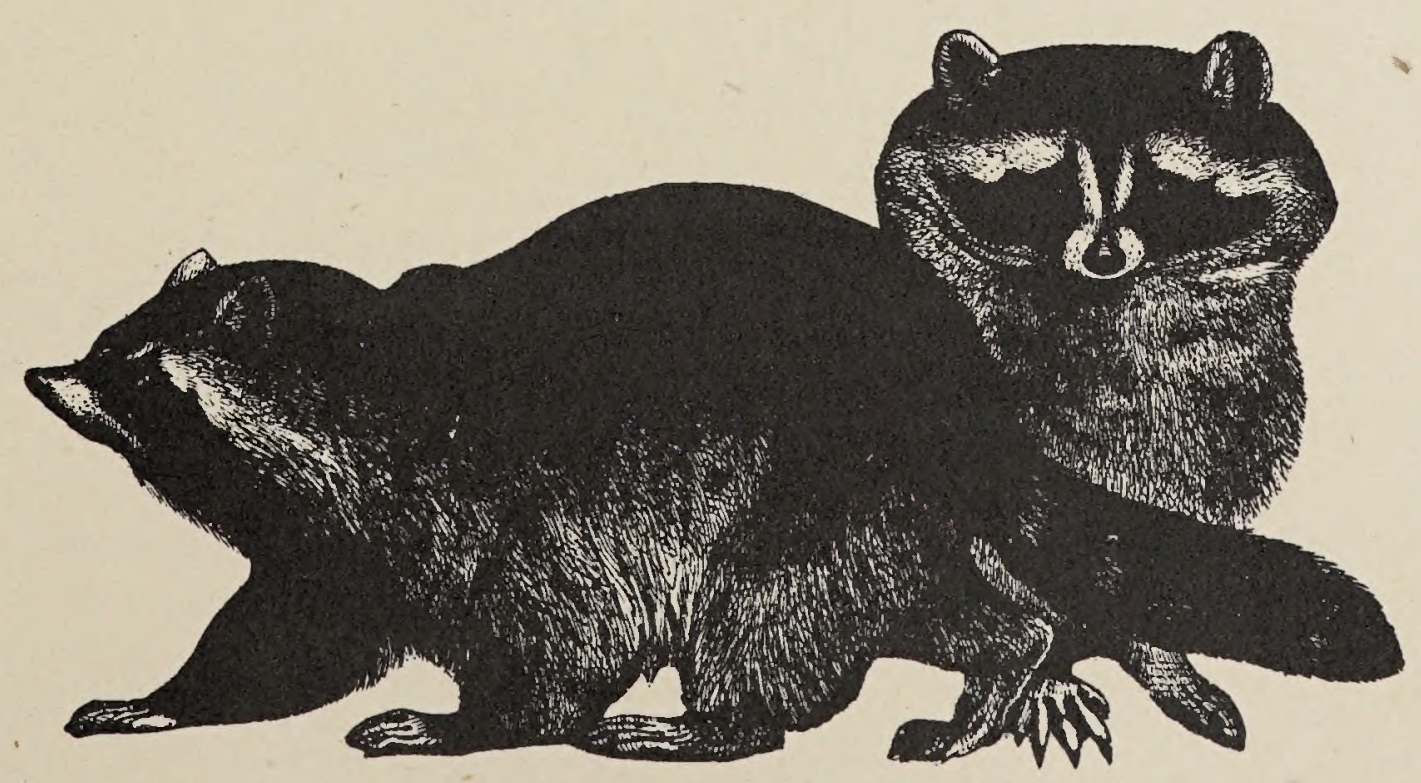


BLM Library Center

Denver Federal 521

Bldg. 50,25047

P.O. Box 250470225 


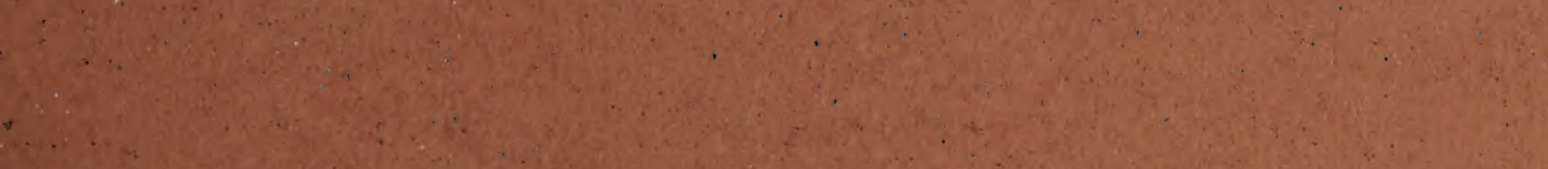

and

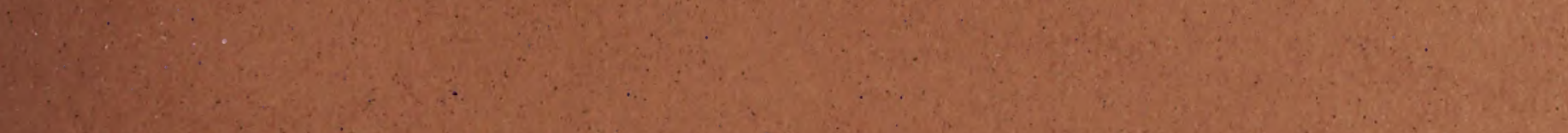

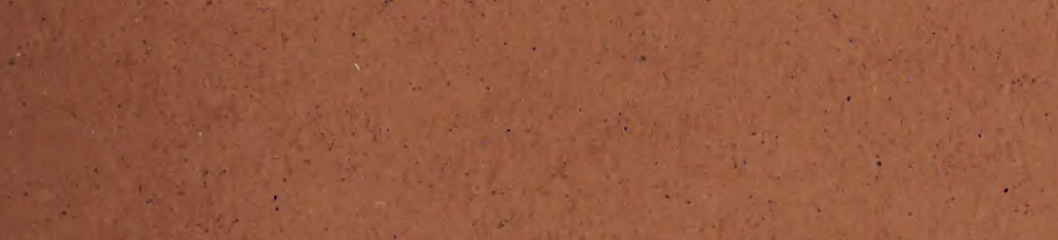

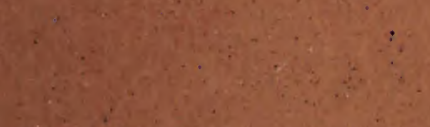

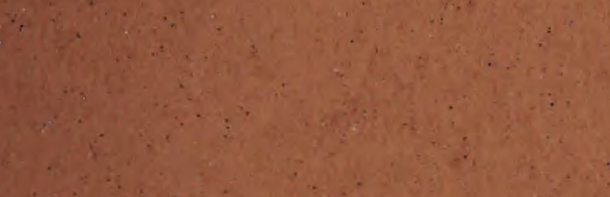

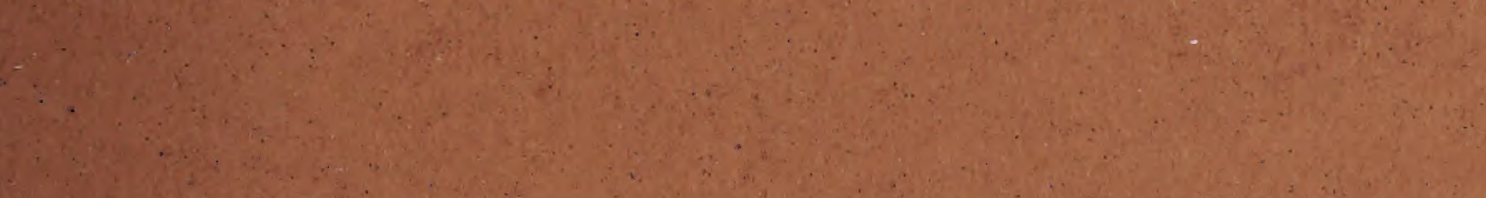

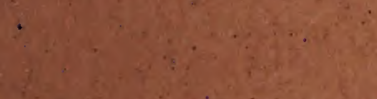

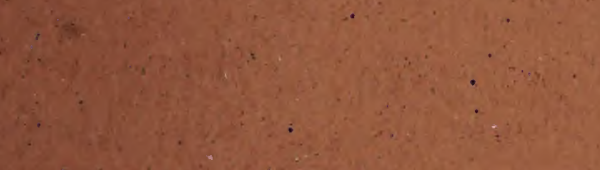

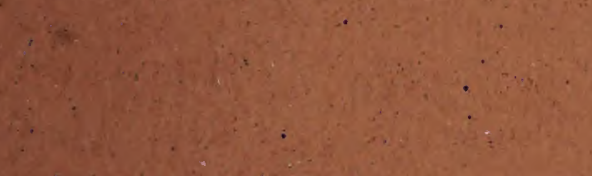

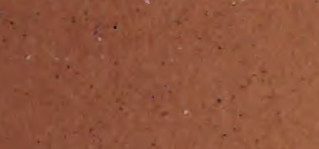

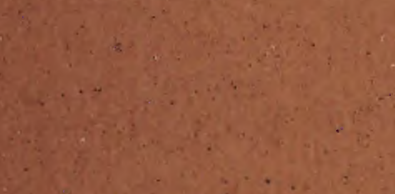

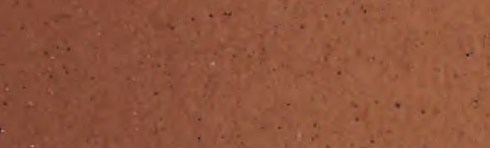

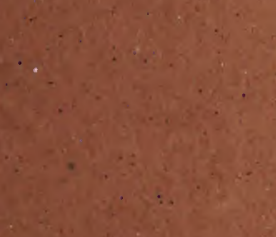

$x^{2}+x^{2}=x^{2}$

$\therefore \quad \therefore \quad(20)$

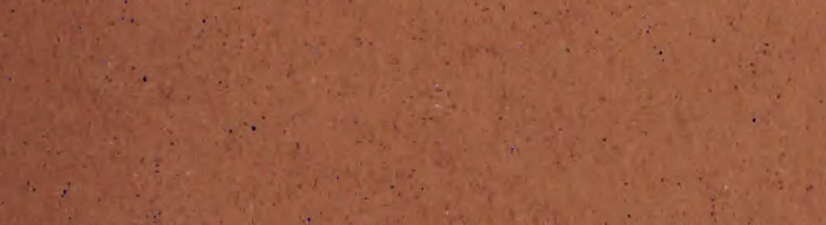

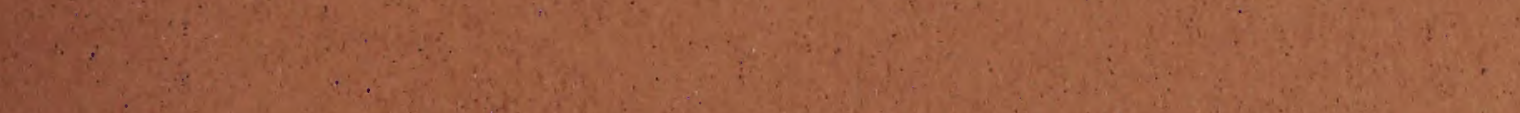

$2 x+2(x)$

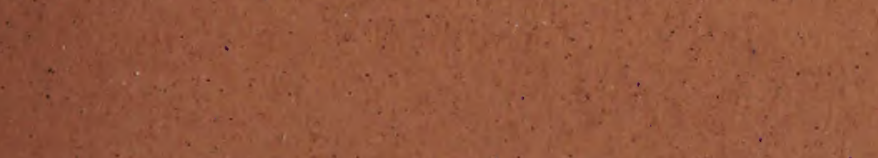

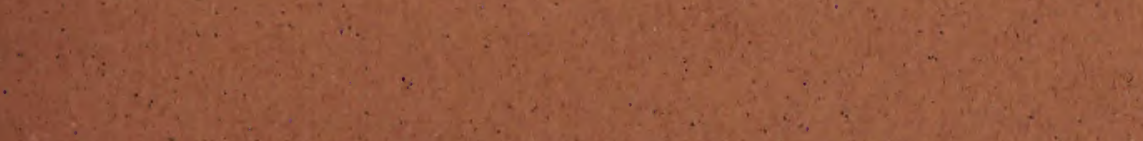
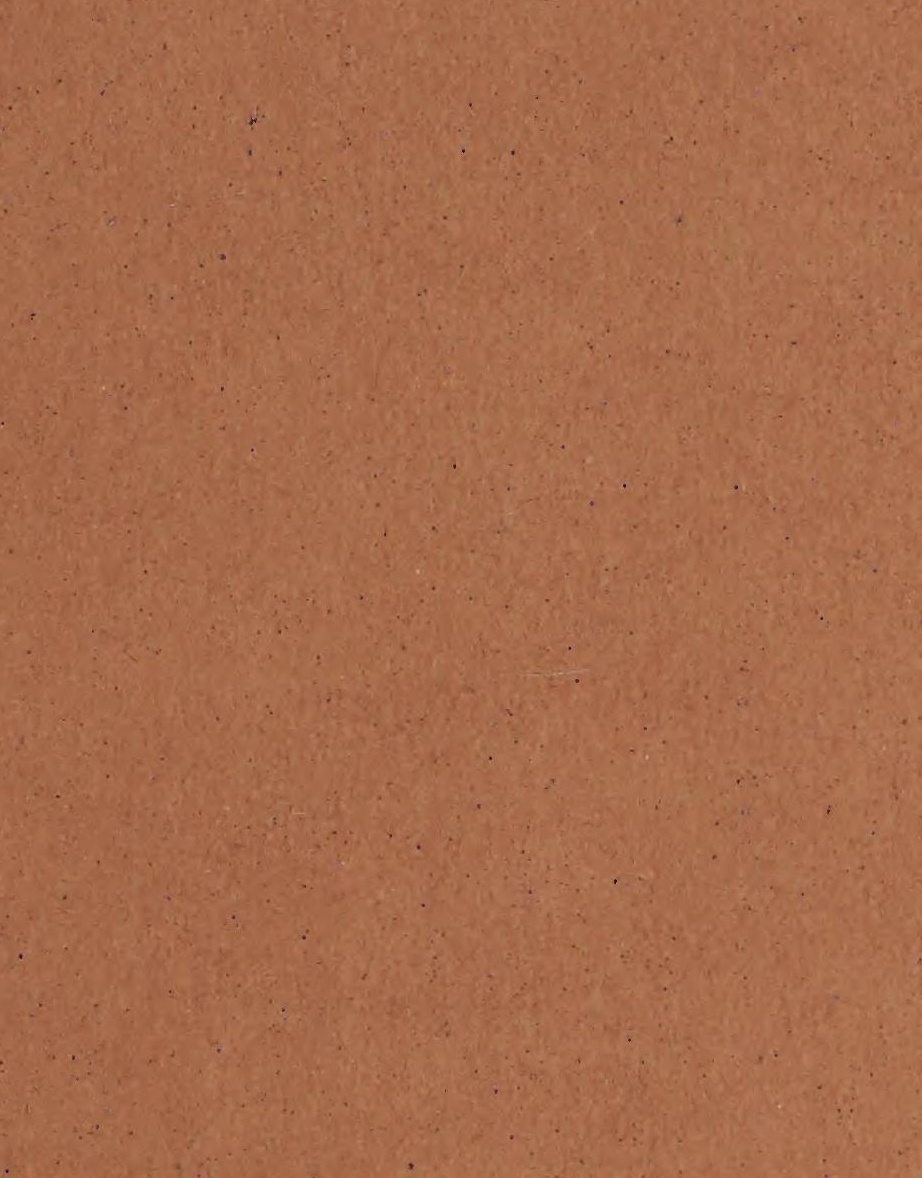

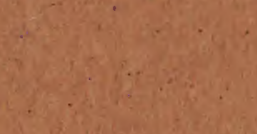

$x^{2}+2$

$x^{2}+x+x+2 x$

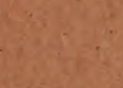




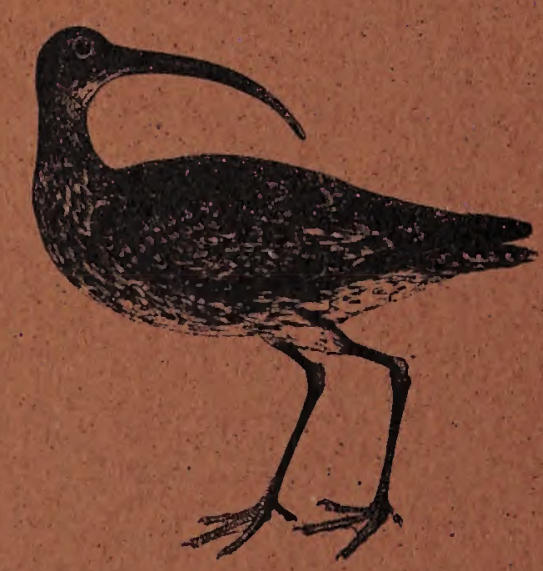

U.S. DEPARTMENT OF THE INTERIOR

BUREAU OF LAND MANAGEMENT

BLM/ID/AE- $95 / 002+1110$

DECEMBER 1994 